HARVARD UNIVERSITY \&

Library of the

Museum of

Comparative Zoology 






\section{ZOÖLOGICAL RESULTS}

OF

\section{THE HASLER EXPEDITION.}

PUBLISLED BY PERMISSION OF PROF. B. PEIRCE, SUP'T OF TILE U. S. COAST SURTEY.

\section{ECHINI.}

Br ALEXANDER AGASSIZ.

Cambridge, February, 1874. 



\section{ILLUSTRATED CATALOGUE}

OF THE

\section{MUSEUM OF COMPARATIVE ZOÖLOGY, \\ AT HARVARD COLLEGE.}

No. VIII.

\section{ZOÖLOGICAL RESULTS OF THE HASSLER EXPEDITION,}

PUBLISHED BY PERMISSION OF PROF. B. PEIRCE, SUPT OF THE

U. S. COAST SURVET.

I.

ECHINI, CRINOIDS, AND CORALS,

By Alexander agassiz and L. F. de POURTALìs.

WITH TEN. PLATES AND FIFTEEN FIGURES PRINTED IN THE TEXT.

UNIVERSITY PRESS, CAMBRIDGE,

WELCH, BIGELOW, \& CO.

1874. 

A preliminary notice of the Sea-urehins collected on the IIassler Expedition was given in the Bulletin of the Museum, Vol. III. p. 187, January, 1873. The more interesting speeies are here described in detail, with figures of those species which are not found in the Revision of the Echini, and which complement the generic representations. The material collected has enabled me to make corrections and additions to our knowledge of several of the speeies of Echini, and many points interesting for the geographical distribution of the order have beer added.

At a depth of one hundred fathoms, off the Barbadoes, a large number of species of Echini were dredged, showing that the deep-sea famma characteristie of the Pourtalès Platean, in the Straits of Florida, extends as far south as the Barbaloes. The following list of the Echini famma of that point will prove interesting. The species collected at a depth of one lrundred fathoms were,

Dorocidaris hystrix,

Salenia varispina,

Hemipedina cubensis,

Trigonocidaris albida,

Clypeaster subdepressus,

Echinocyamus pusillus,

Paleopneustes cristatus,

Metalia grandis,
Asthenosoma hystrix,

Coelopleurus floridanus,

Temnechinus maculatus,

Echimus gracilis,

Mellita hexapora,

Echinolampas depressa,

Meoma ventricosa,

$\Lambda$ gassizia exeentrica. 
Salenia varispina has been dredged by Thomson," in deep water, off the coast of Portugal; so that, to julge from the species thus far observed, every exploration adds to the number of deep-water species which have a wide geographical range. Coelopleurus has been dredged by Thomson off the Bermudas, as well as a small Ananehytes-like Echinus, probably Paleopneustes cristatus.

Of the shallower water species we find as far sonth as Cape Dos Bahias species found in the West Indies, and extending northward along the eastern const of the United States. Dorocidaris hystrix and Toxopnenstes variegatus . appear to be common at Cape Dos Bahias, and are found associated with the following Patagonian species: Echinus margaritaceus ( 55 fithoms), Echinus magellumicus, and Coniocidaris camaliculata. So that, as far as the Echini are concerned, Cape Dos Bahias seems to be the dividing line between the Patagonian and the tropical $\Lambda$ tlantic distriets.

Along the eastern Patagonian coast and the Straits of Magellan only species already known were collected. The following species, not especially mentioned in this report, were collected from localities not recorded in the Revision of the Echini; very fine and large specimens of Goniocidaris canaliculata, measuring nearly one and a half inches in diameter, from Lat. $51^{\circ} 26^{\prime}$ South, Long. $68^{\circ} 5^{\prime} \mathrm{West}, 57$ fathoms; Strongylocentrotus albus, Port Gallant, Patagonia ; Schizaster Philippii, in Snyth's Channel, 35 fithoms.

On the west coast of South America, nothing of great importance was collected. The collections male at the Galapagos show satisfactorily that this group of Islands forms a part of the Panamic District. None of the Fehini of the East India types, usually said to exist there, were found. Only the following species, all known, from the west coast of Central America, were obtained at the Galapagos Islands: Cidaris Thouarsii, Echinometra Van Brunti, Strongylocentrotus gibbosus, Toxopneustes semituberculatus, Encope micropora, Rhynchopygus pacificus. With the exception of $\mathbf{E}$. Van Brunti, collected at Charles Island, the other species came from Indefatigable Island.

* W. Thomson, Nature, March, 1873. 


\section{Asthenosoma hystrix}

! Calveria hystrix W. Thoms, 1869, l)redg. Rep. Por'upine.

: Asthenosoma hystrix A. AG., 1872, Rev. Ech., 1't. 1. p. 93.

$$
\text { Pl. II.f. } 1, \text {. . }
$$

A fine speeimen of this species was dredged off the Barbadoes in 100 fatloms. This has emabled me to examine more in detail this remarkable sea-mehim, and to satisfy myself of the correctuess of the systematio views held by Thomson regarding it. In the Revision of the Echini I still included the genus among the Diadenatidae. I am now convinced, from study with better material, that Thomson is correct in separating these Echini as a distinct family from the Diarlematidae, for which he proposes the name of Echinothuritae; in his Prelininary Report* he has given some of the reasons for this course; they are to be found more in detail in the Depths of the Sea.t The association with Echinothuria may be somewhat doulstful, as we harlly know the genus accurately enough for such an intimate association, in spite of the ingenious and eareful examination made of the fragments by Woodward. + Echinothuria has, in common with Asthenosoma, the reverse lapping in the coronal plates and in the buccal membrane; but the strueture of the ambulacral and interambulacral systems can only be guessed at in the fragments of the fossils which have thus far come to light.

The separation of this fimily from the Diadematidae is made on account of the mailed structure of the coronal plates lapping in opposite directions in the ambulacra and interambulacra, on account of the perforated anbulacral plates, and the extension of the ambulacral tubes to the actinal opening, throngh the buccal membrane, which is mailed as in Cidaris.

The specimen figured in $P l . I I . f .1,2$ was, when brought up in the dredge, of a deep claret color. The test is perfectly flexible, owing to the lapping of the plates and the deposition of the limestone only in rertain parts of the ambulacral and interambulacral plates, leaving a part of the elges of the plates, where they do not lap, free from limestone. Secu from above, the outline is pentagonal, with romded comers; the central part of the test is depressed from its own weight. The contrast between the actinal and abactinal surfaces is very marked, owing to the flatmess of the test, - the height of the edge of the test not equalling more than one fifth its diameter. The width of the ambulacral zone at the ambitus is about half that of the interambulacral area. The number of plates along the median ambulacral

* W. Thomson, 1873, Preliminary Report of the Porcupine Echinoderms. Proc. R. S.

$\dagger$ " "Depths of the sea. Figs. 27, 28, PP. 156, 157.

‡ Woodwarn, Guologist, September, 1863. 
line is but little larger thin the number of interambulacral plates. On the actinal side fifteen of the former oceupy the same space as twelve of the latter, and on the abactinal side the proportion is thisteen to ten. On Pl. $I I^{c} f \cdot z^{a}$ of the lievision of the Echini 1 have given an internal view of a portion of the test, showing the lapping of the plates of the two areas in opposite directions, and the arrangement of the poriferous zone; the median ambulacral part of the plates lap from the actinostome ; the median interambulara and the plates of the buecal membrane towards the month. Something similar is found already in Astropyga, where we have a greater degree of flexibility in the coronal plates of the actinal surface than in other Diadematidae.

There is on the actinal side, adjoining the poriferous zone, a row of large primary interambulacral tubercles, occupying the outer extremity of the plate; these large tubercles are surrounded by a flat scrobicular circle, raised above the edge of the test, with sunken scrobicular area. This row extends to the ambitus, and becomes very irregnlar on the abactinal side of the test; a few smaller tubercles, larger than those of the rest of the plates, extend towarls the apical system. On each side of the median intermnbulacral line, on the actinal side, a smaller vertical row of tubereles, less distinet, and at a greater distance from the edge of the plate, extends somewhat beyond the ambitus. $\Lambda$ similar row of tubereles extends in the median ambulacral space, on each side of the median line, reaching but little beyond the ambitus. The remaining part of the coromal plates is occupied, both in the aubulacral and interambulacral spaces, by small secondary tubereles and miliaries, irregularly arranged, with deeply sumken scrobicular areas and raised edges, as in the primary tubereles, forming, in the case of the smallest miliary tubercles, deep pits.* On the abactinal side the pits form irregular Lorizontal lines, parallel to the sutures, in the central part of the plates. The whole abactinal system is similarly pitted by secondaries and miliaries. The anal system is large, composed of rather irregularly shaped polygonal plates; the genital plates are triangular, small, with genital openings near the outer edge. The oeular plates are small, polygonal, reaching the anal system; they are separated from the genital plates hy anal plates, one on

* Something analogous to this is found in Astropyga. If we examine (from the interior) the actinal surface of a large Astropyga, we find deep pits extending into the base of the primary tubercles, which are bollow; this same structure, more fully developed, forms the sunken scrobicular areas of Asthenosoma; among Spatangoids it is highly developed in Lovenia, where the sunken areas form pouches in portions of the interambulacral areas. 
each side, intercalated between them and the genital plates; the madreporie borly is elliptical, quite prominent; anal opening central, or nearly so.

The ambulacral tentacles are provided with suckers on the actinal side, from the actinostome to the ambitus. On the abactinal side they are pointed, as in Diadematidae. Only one row of snekers extends from the auricles to the actinostome on each side of the ambulacra; there are no actinal cuts in the buccal membrane, as in Cilaris. The anrieles are low,

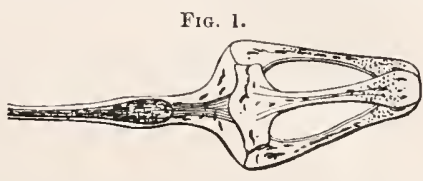
Fra. 2. slender, with wide anricular foramen. The buccal membrane is thickly covered by short, club-shaped spines, and minute, short-stemmed, small-headed pedicellarie. The spines of the primary tubercles are curved, hollow, flaring at the extremity. A section of the primary spines $\left(P l . I I^{c}\right.$. f. 5., Rev. Ech.) shows a structure similar to that of the spines of Diadematidae. The secondary spines are less curved and more cylindrieal, while the smaller, thin, silk-like spines are straight; the miliaries of the whole surface of the test carry a number of large-headed, tripartite pedicellaria with long, slender stems (Fig. 1, and a fur greater quantity of similar pedicellarie, but with smaller heads, probably the younger stages. In addition there are a number of short-headed (Fig. \&) pedicellaria scattered over the whole test, more numerous, however, on the actinal side.

\section{Astropyga pulvinata}

! Cidarites pulvinata LAмк., 1816, A. s. V.

1. Astropyga pulvinata AGass., 1546, Cat. Rais.

\section{Pl. I.f. 1, . .}

I have nothing to add to the descriptions of this species given by $\mathrm{Mr}$. Verrill* and myself. $\dagger$ As no figure of older specimens of this species covered with its spines has been published, I have given in P'l. I. $f .1,2$, views from above and below of a specimen intermediate in size between those figured in the Revision of the Echini, $I^{\prime} l . I I I^{a} \cdot f \cdot 4_{4}$, and $P l . I I I^{b} f .4,5$; the length of the spines of this specimen is in striking contrast with the length of the spines of all the speeimens of Astropyga radiata which I have thus far seen.

Panama; eollected by Lieutenant Cutts.

* Verirll's Notes on Radiata, p. 296, 579.

$\dagger$ A. Agassiz, Revision of the Echini, Part III. p. 418. 


\section{Arbacia Dufresnii}

! Eehinus Dufresnii Blaixy., 1825, I). N. Se. Nat. O.

! Arbacia Dufresnii Gray, 1835, Pruc. Zoöl. Soc. London.

$$
\text { Pl. I. f. 3, 4. }
$$

Aiditional specimens of this species, collected in the Straits of Magellan by the IIassler Experlition, confirm the value of the specific characters employed to separate $\Lambda$. Dufresnii from $\Lambda$. stellata, its nearest ally. It is quite remarkable that in the fow specimens existing in the British Musem and in our collection, there should be two specimens laving five anal plates, instead of the normal number of four in the other species of the genus. This may explain the rudimentary fifth anal plate of some specimens of Parasalenia seen by Trosehel.* He was, howerer, mistaken in considering Parasalenia, on this account, the young of some Echinometra. 'The young of Parasalenia is what I had called in some collections Clatosalenia, but which I lave since found to be only small Parasaleniae. In all the Echinometrae known to me the anal system is covered by a large number of anal plates, long before the specinens attain even one fifth the size of the specimen of Parasalenia figured in $\mathrm{Pl}$. $I I I^{l} \cdot f \cdot 1,2$, of the Revision of the Echini. I eamot agree with Trosehel in separating Arbacia into two genera, for which he has proposed the names Echinocidaris and Pygomma, based upon the position of the ocular plates. The ocular plates, as is well known among young Echini, $\dagger$ have at first no commetion whaterer with the abactinal system, and in the Eehini proper and Eehinometradae, they either reach the anal system, or are exchded from it in specimens of nearly the same size. The only family thus far where the position of the ocular plates seems of generie value is in the Diadematidae; but there the ocnlar plate is comnected with some of the anal plates, in such a mamner as to separate all the genital plates. and the separation is not limited to one or two plates, as in the families above mentioned. Professor Troschel, during my visit at Bonn, in 1870 , called my attention to his views of the value of this character, but I have been umble, after a careful examination of the large material at my command, to satisfy myself that this feature has the importance he would assign to it; owing to the great variation in the position of the ocular plates in the species, he includes in his genus Pygomma, where it is often impossible to decide if the ocnlar plate really reaches the anal system or simply spreads apart the genital plates.

* Troscnes, Die Familie der Echinocidariden, 1873, Wieg. Archiv.

† A. Agassiz, Embryology of Echinoderms, Mem. Am. Aead., 1863. 
Troschel maintains, also, Tetrapygus as a separate genus; for reasons already stated ${ }^{*}$ I do not think he is correct. The property possessed by the Arbaciadae of resolbing at any time during their growth the primary abactinal interambulacral tubercles, and changing them into a sort of chagrin, or finely granular, nearly bare abactinal star, is not of generic value, as specimeus in this condition of growth are found of all sizes, up to the largest, in species which Trosehel does not place in the genus Pygomma (A. stellata, A. Dufresnii, A. punctulata, A. pustulosa), and on the strength of which he separates Echinocidaris into two subgenera, which appear to me not valid, if I am correct in my interpretation of the number of species. Troschel objects to the identification, on geographical grounds, of A. pustulosa, A. sequituberculata, and A. loculata. I ean only say I lave carefully compared large series of the first from Brazil, of the second from the Mediterranean, Azores, and Madeira, and of the third from Liberia and Cape Palmas, and am compelled to mite them all under one specific name. This is not the only species found on the two sides of the Atlantie, common to the West Indies, Brazil, Azores, Mediterranean, and Cape Verle Islands. The number of common species is daily increasing : compare list given in the Geographical Distribution of the Revision of the Echini, Part I. p. 232, Southern Brazil to Eastern Virginia; and p. 234, Portugal to West Coast of Tropical Africa.

San Matias Bay; Straits of Magellan; Eden Harbor; Lat. $37^{\circ} 42^{\prime}$, South; Long. $56^{\circ} 20^{\prime}$, West.

\section{Arbacia spatuligera}

! Echinus (Agarites) spatuliger VAL., 1846, Voyage Vénus.

L Arbacia spatuligera $\Lambda$. Af., 1872, Rev. Eeh., Pt. I. p. 93.

A few specimens of this species were collected by the Hassler Expedition at Payta. Troschel dissents from my views in associating A. grandinosa with A. pustulosa, because it is found, he says, on the west coast of South America. Valeneiennes's original came from Carthagena, on the east side of the Isthmus of Darien, and is not to be distinguished from E. pustulosa. The confusion which Troschel seeks to remedy by reconciling the synonymy with the citations can only be rectified from an examination of the originals. Thus there is no possibility, in the case of $\mathrm{A}$. Dufresnii, of mistaking Blainville's original, which eertainly did not come from Newfoundland. What has beeu called E. grandinosa by various writers has undoubtedly been collected on the west coast of South America; but the specimens are either A. stellata or A. spatu- 
ligera, both of which, according to the comparison of original specimens with others of undoubted locality, are found on the west coast of South America.

\section{Coelopleurus floridanus}

! Coelopleurus floridanus A. Ag., 1872, Rev. Ech., Pt. I. p. 102.

$$
\text { Pl. I.f. } 5-7 \text {. }
$$

Troschel has limited the family of Echinocidaridae to the old genus Echinocidaris, and does not include in it either Podocidaris or Coelopleurus, which I believe belong to the family of Arbaciadae. As for Podocidaris the merest inspection of the figures (on $P l . I V \cdot f . s-15$, Rev. Ech.) and comparison with the figures of young Arhacia (Pl. $T$., Rev. Ech.) cannot fail to show such a close homology that at first sight Podocidaris wonld most naturally be considered the young of some species of Arbacia. If we add to this the structure of the spines, of the poriferous zone, of the tentacles, of the pedicellaria, of the abactinal system, and of the actinostome, all of which are strikingly similar to the structure of corresponding parts of Arbacia, I think I am justified in placing Podocidaris among the Arbaciadae.

Where Troschel conceived the idea that I had associated Parasalenia and Trigonocidaris with the Arbaciadae I am at a loss to know. As regards Coeloplenrus, the additional details here given of Coelopleurus floridams will, I think, convince Professor Troschel that my association of the spines figured on $P l . I I^{c} . f .14,15$ (Rev. Ech.) with Keraiaphorus Maillardi was correct. Their generic identity I should never have dared to suggest or even to defend, from fragments of single spines, for any other genus of Echini; but in this case the spines are so unlike (the long abactinal spines) anything else known amoug Echini, either living or fossil, that had Professor Troschel ever seen the spines of the Bourbon specimen, he would not have hesitated to identify the grenera. There were in Cambritge a number of spines of Keraiaphorus, given to me by Professor Bayle; my identification was made after careful comparison of the exterual appearance and structure of the spines.

The figures of Coelopleurus (Keraiaphorus Maillardi) given by Michelin seem to have escaped Troschel, for he certainly would not have doulsted the position of the genus among Arbaciadae, as he has done; and after comparing them with Coelopleurus, he could not fail to see their identity. At the time of my visit to the École des Mines I made a most careful comparison of the test of Keraiaphorus, of Coelopleurus, and of Arbacia, and 
came to the conclusion that Coclopleurus was elosely allied to Arbacia, and belonged to the sane fimily, - a view also held by Lütken, from an inspection of Michelin's figures.

The details which I am able to give regarding Coelopleurus floridanus will, I think, leave no doubt of the correctness of the generic identification of Coclopleurus floridanus and Keraiaphorus Maillardi, and of their systematic position among Arbaciarlac. Fragments of the test, and a large number of pieces of larger spines show that the West India species must attain fully the size of the Bourbon species.

In the young specimens figured $(P l . I . f . \sigma, r)$, which are magnified four diameters, the actinostome is large, having already the peculiarly shaped lips of the actinal cuts of all Arbaciadae; though, as in the young of Arbacia, the cuts are as yet but mere indentations, and remain so in this gemus; there are two or three deep ambulacral pits between the ambitus and the actinostome. In these young specinens the ambulacral primaries are the only ones extending beyond the ambitus; the narrow poriferous zone forms continuous ares round the base of the primaries. In the interambulateral space the primaries extend from the actinostome, slightly beyond the ambitus, to the bottom of the peculiar, broad, bare, median interambulacral space, which shows as yet only rudiments (minute miliaries) of the marked angular ornamentation of the median part of the interambulaeral plates of the larger specimens.

The ambulacral zones are broader than the interambulacral ones, and are separated from the latter by a narrow vertical row of elosely packed secondary tubercles. Anal edge of genital ring raised; each genital plate carries in the centre near the anal edge a prominent secondary tuberele, of the same size as those of the vertieal row, separating the poriferous zone from the interambulacral spaces, surrounded by a pavement of flat miliaries. The ocular plates carry similar single tubereles on the outer extremity. Anal system elliptical; madreporic genital slightly raised, but not larger than the others.

The largest complete specimen dredged by the Hassler is figured, with all its spines of natural size, on $P l . I . f$. $\pi$. The long curved spines are Fig. 3. carried on the primary ambulacral tubereles; some of them equal three times the diameter of the test. The spines of the interambulacral area, adjoining the poriferous zones, are either rudimentary, attached to the tubercles, or else pointed, with serrate edges (Fig. 3), as they approach 
the ambitus. On the actinal side the spines of both areas are irlentical; they consist of a finely serrate base, above the milled ring, extending half the length of the spine; the upper part is flat, spathiform, with sharp edges; the flat portion of the spine having the amorphous, finely granular (Figs. 4, 5, 6 ) structure of the large spines already described in the Revision

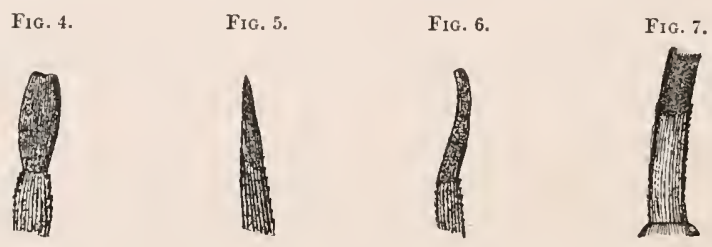

of the Echini. As the spines grow older the serrated collar loses its prominenec (Fig. $\%$ ), and the large ambulacral spines of the abactinal surface appear nniformly granular, with a delicate suture somewhat above the milled ring. The S-shaped curves, so prominent on the abactinal interambulacral spaces of the Bourhon species, are quite apparent in our largest specimens; the miliaries forming independent patelies or triangular figures, extending alternately from the median line of the plates towards the poriferons zone. The miliaries earry pedicellaria on long, stout stems, like those of Podocidaris, with a comparatively small head. The ambulacral suckers are pointed towards the abactinal pole, as in all Arbaciadae, and have prominent, welldeveloped suckers on the actinal side. The actinal membrane is bare, with the exception of ten large buccal plates, which carry clusters of small pedicellaris. The teeth do not differ from the teeth of the Bourbon species and of the Arbaciadae.

The anal and ocular plates carry small pedicellaria and minute rudimentary spines. The long collar of the base of the primary spines reminds us of a similar structure in Porocidaris, figured by Thomson* in his Depths of the Sea. The outer granular part of the spines of this genus is formed subsequently as a tip to the basal portion, without the usual cellular sheath which forms the longitudinal serrations of Echini spines. This gives us an explanation of the apparently aromalous strueture of the base of the older spines of these two genera, which appear as if they had been broken off and soldered again. This granular addition is the homologue of a similar tip, which is found in all Arbaciadae, and las been particularly well described by Desmoulins. It remains always as a flat, spathiform appendage in the shorter spines of

* Thomson, W., The Deptlis of the Sea, 1873, p. 102, f. 11. 
the actinal side of Coelopleurus (Figs. $4,5,6$ ), while it develops into the long, hooked, curved spines (Fig. $\tau$ ) of the ambulacral system on the abietinal sicle of the test, as well as on the lower interambulacral spines nearest the actinostome. In the Arlaciae this appendage remains a sort of cap only on the spines of the actinal side, and is not developed on the spines above the ambitus, as is the case also in most of the serrated interambulacral spines above the ambitus.

The anal system is covered by four anal plates of slightly unequal size; in larger specimens the anal edge of the plates carry small gramules and minute secondaries, while in smaller specimens the plates are smooth or very minutely chagriner. Fragnents of the test, dredged off the Barbadoes, show that this species must have attained al diameter of at least an inch and a quarter:

100 fathoms, off the Barbadoes.

\section{Echinus magellanicus}

! Eehinus magellanicus PunL, 1857, Wieg. Archiv.

$$
\text { Pl. III. f. } 5 \text {. }
$$

A large number of specimens were collected at different points through the Straits of Magellan. The denuded test figured on Pl. III.f. 5, shows the great similarity of this species to E. mierotuberculatus from the Meriterranean ; like it, the South Ameriean species does not appear to attain as large a size as the more northern E. miliaris.

Lat. $37^{\circ} 42^{\prime}$, Soulh ; Long. $56^{\circ} 20^{\prime}$, West.

Siraits of Magellan; Magdalena Islands; Eden IIarbor; Sandy Point; Shoal Bay. Lat. $49^{\circ} 40^{\prime}$, South; Long. $66^{\circ} 50^{\prime}$, West. 57 fathoms.

\section{Echinus margaritaceus}

! Echinus margaritaceus LAM., 1816, An.s. Vert.

$$
\text { Pl. II. f. } \theta ; \text { Pl. III.J. 4. }
$$

A figure of the large specimen described in the Revision of the Eehini (Part III. p. 493) is given on Pl. II.f. G. A good series of various sizes wals collected by the Hassler Expedition, at different points along the sonthern extremity of South Amerien. The changes due to growth are similar to those observed in E. norvegicus, to which this species is most elosely allied. A younger specimen is also figured in Pl. III.f. 4, showing satisfactorily that E. magellanicus camnot be the young of E. margaritaceus, as the latter has, when not more than half the size of the former, a larger number of primary interambulacral tubercles. 
The specimens colleeted at Juan Fernandez are all small, and are referred with some doubt to this species.

Juan Fernandez; Cape Dos Bahias (East Coast of Patagonia).

\section{ENCOPE. (Monopilora.)}

Monophora AGAss., 1817, in Des., Bull. Soc. Geol. Fr., IV. 287.

A number of almirably preserved specimens of this genus have enabled me to figure this interesting species, and to give some important details regarding its aflinities, and the correlation of ecrtain characters among Sentellidae, which will be of considerable systematic value.

The marginal limestone network connecting the actinal and abactinal floors extends about half-way from the edge to the actinostome ( $P l . I I I$. f. 3 ) ; it resembles the marginal supports of Encope, showing no radiating separations between the pillars, in the median ambulacral and interambulacral spaces, as in Mellita ; this feature Mellita has in eommon with Echinirachnins. The walls separating the cavity of the jaws from the alimentary canal are low ridges, corresponding in their course to the windings of the analogous broad walls of Encope. The jaws, or rather the fragments which were preserved, resembled the jaws of Encope; the auricles are slender, elongate. The marginal ambulacral indentations are reduced to mere re-entering angular sides ( $P l . I I I . f .2)$, resembling the anterior ambulacral indentations of some specimens of Encope Michelini (Pl. XII ${ }^{\circ} . f .4$, Rev. Ech.). The anbulacral furrows are broad, shallow (Pl. III. $f .1)$; the two main branches diverge towards the edge, where they send off thin marginal shoots, ramifying but once or twice; the main branches send off short, narrow, usually simple branches. As in all Eneopida the median ambulacral and interambulacral spaces on the actinal side are covered by elongate triangular bands of large sunken tubereles, largest nearest the actinostome in the interambulacra, and nearer the edge in the ambulacra; white on each side of the ambulacral furrows the tuberculation is minute and uniform. Posterior interambulaeral lumule with raised edges on the abactinal side. Tuberculation of abactinal surfice uniform. Five distant genital pores. Petals resembling those of Mellita, unifornly petaloid, somewhat open at extremity. The characters of this genus seem to show that we can consider Monophora only a subgenus of Encope, as well as Ravenellia of Liitken (non McCrady), which 
is intermediate between it and Encope proper, though in such forms as Encope Michelini and Encope grandis it is difficult to trace the precise limits of these subgenera.

\section{Monophora Darwinii}

Monophora Darwinii Desor, 1847, Bull. Soc. Géol. Fr., IV. p. 287.

\section{Pl. III.f. 1-s.}

At first glance, seen from above, this species would be taken for an Echinarachnius, with a posterior interaubulacral lunule; the actinal ambulacral cuts are reduced to slight angular indentations, giving the nearly circular outline of the test a lobed appearance. The apical system is somewhat eccentric posteriorly; the ambulacral petals short, extending but little beyond half-way to the edge of the test from the apex. The odd anterior petal is somewhat longer than the anterior pair ; they, in their turn, are longer than the posterior ones. The poriferous zones are broader than the median interporiferons space; the poriferons furrows distinet and closely crowded with pores. The vertical margin of the test is covered by two or three irregular rows of large tubercles, larger than any on the actinal surface. The edge of the lunule is raised on the abactinal side, where it is small, elliptical; on the actinal side it is larger, and connected by a shallow groove with the anal opening; the latter is placed about half-way between the edge of the test and the actinostome. The actinostome is, like the apical system, eccentric, posteriorly circular, with prominent buccal tubes.

San Mathias Bay (probably tertiary).

\section{PALEOPNEUSTES.}

Paleopneustes A. AG., 1873, Bull. M. C. Z., III. No. 8, p. 188.

One of the most interesting of the Spatangoid genera dredged by the Coast Survey Expeditions is undoubtedly Paleopneustes, the representative in onr days of Ananchytes, one of the most prominent and most common eretaceous genera, and resembling it in outline and general appearanee to such an extent, that the only species of this genus thus far obtained would, at first sight, readily pass for Ananchytes gibbosa. A closer examination of the denuded test shows that, unlike Ananchytes, the upper part of the lateral ambulacra is imperfectly petaloid. The abactinal system is like that of true Spatangoids, generally compact, and not elongate, - a structural feature which 
does not prevent its elose association with Ananchytes. We have already, in some eretaceous genera, Stenonia, * closely allied to Ananchytes and Ilolaster, a compact abactinal system. It has neither peripetalons nor anal and subanal fascioles. The actinal plastron is elongate, triangular; the tuberculation of its posterior extrenity passing into the tuberculation of the posterior interambulacral space roumi the anal system. Test ligh, conical; sharply defined ambitus; actinal surfice flat. Actinostome transverse, eccentric anteriorly; posterior lip very prominent. Anterior ambulacrum flush with the test, male up of pairs of minute pores in the central part of the plates, extending to the ambitus. The semipetaloid part of the lateral ambulacra very slightly sunken; poriferous zones very slightly diverging, composed, as in Asterostoma, of an inner circular pore and an outer comma-shaped pore. Anal system placed above the ambitus, in the truncated posterior extremity of the test. Tubereles perforate, cremulate, earrying, on the abactinal part of the test, straight, short spines, fincly striated, with serrate edges; they become somewhat curved towards the ambitus, and on the actinal surface are longer, eurved, spoon-shaped at the extremity, especially those of the actinal plastron. This genus shows even greater affinities to Asterostoma than to Ananchytes. It has the ambulacral system of that genus as figured by Cottean, $\dagger$ in his note on Asterostoma. The structure of the abactinal system is the same. But, as far as can be judged from Cotteau's descriptions and the figures of D'Orbigny, $\ddagger$ the structure of the actinal surface is very different in Asterostoma; the presence of actinal grooves is so unlike the structure of any other Spatangoids, that I have preferred establishing a new genus for this species, rather than place it in a genus with the anomalous and imperfectly known actinal structure of Asterostoma. The figures given by Dorbigny of the actinal surfice differ essentially from the descriptions of Cottean. Cottean says distinetly the nonth of Asterostoma is labiate, while D'Orbigny's excellent figures, on the contrary, show a Clypeastroid or a Cassiduloid actinostome.

\section{Paleopneustes cristatus}

I Paleopneustes cristatus A. AG., 1873, Bull. M. C. Z., III. No. 8, p. 188.

$$
\text { Pl. Il:f. } 1-s \text {. }
$$

Outline of test, seen in profile, regularly arched anteriorly; apical portion

* Jesor, Synopsis Echin. foss., Pl. X:YXIX. f. 10.

† Cotteat, Note sur le genre Asterostoma MÍm. Soc. Géol. de Fr., No. II. 2. Súr. IX, Pl. I, II.

‡ D'Onbigixr, Pal. f. Terr. Crét., Pl. 906, 907, 908. 
of the test somewhat conical; posterior extremity arching somewhat less from the apex to the anal system, which is placed in the truncated extremity, slightly coneave towards the anterior of the posterior interambulaeral space. The sides of the test rise nearly vertically from the ambitus, enrving slightly as far as the extremity of the petals, where the test slopes more rapidly to the apical system. Seen from above the outline is elliptieal, rounded anteriorly, with slightly angular sides; posterior interambulacrum somewhat pointed, rounded, projecting beyond the general outline. Aetinostome anterior, sumken, with test sloping rapidly towards it from the anterior extremity. Aetinal surface flat, with sharply rounded ambitus. Posterior lip of actinostome prominent; actinal plastron slightly sloping from the central line towards the bare, broad, posterior, lateral ambulacral avenues; the whole actinal surface, with the exception of the ambulacra, covered by large tubercles, uniformly seattered, and comparatively (to the abactinal surface) erowled with distant miliaries; in the intervening spaces the miliaries alone extend over the bare posterior ambulacral avenues, while in the lateral anterior ambulacra, close to the actinostome, adjoining the large actinal suckers, small secondary tubereles are found.

The imperfectly petaloid portion of the lateral ambulacra consists of a large interior round pore, with a large exterior comma-shaped pore. The interporiferous zone becomes gradually broader towards the extremity of the petals; it is smooth, and is flanked by the poriferous zone, which is as broad as the median spaec, and attains its greatest breadth quite near the apieal system. The petals of the lateral ambulacra extend about half-way to the ambitus; the posterior pair are somewhat the longest. Below the petals the poriferous zone consists of minute pairs of pores, placed in the centre of the plates, extending to the ambitus; they are larger on the actinal side, and form a very marked phyllode in the ambulaera round the actinostome. The petaloid portion of the lateral ambulacra is slightly sumken near the apical system, and becomes flush with the test at the extremity of the petals. The odd ambulacrum is flush with the test, and wholly composed of minute, distant pairs of pores, placed in the central part of the ambulacral plates, as in the lower part of the lateral ambulacra.

On the abactinal surface the tubereles are uniformly seattered, distant, arranged irregularly in short, curving lines, on the central part of the plates, leaving the edges of the plates bare, forming thus bare median interambulacral and ambulacral sutural spaces, as well as bare, horizontal sutural mar- 
gins; mimute distant miliaries are irregularly scattered between them, and extend over the whole test; the abactinal tubercles are larger and somewhat more crowded in the intermbulacral spaces adjoining the petaloid portion of the lateral ambulacra. In the odd ambulacrum these large tubercles are limited to the abactinal part of the interambulacrum, where they are elosely erowded together, and, carrying, as they do, larger spines, form a sort of tuft near the abactinal pole. The larger spines adjoining the petals protect them, somewhat as in other Spatangoids, by arehing over them. The remaining spines of the abactinal surface are finely serrated, short, straight, resembling at first sight the spines of the regular Echini (Fig. s). They stand out in all possible directions from the test, and have not a general trend, as is the ease in all Spatangoids. The spines of the actinal side are somewhat curved, much longer, spoon-shaped at the tip, finely striated, but not serrated (Fig. 2), except near the ambitus, where the spines become straighter and shorter. The spines of the actinal surface trend all in one direction. A transverse seetion of one of the actinal spines (Fig. 10) shows the general structure of Spatangoid spines. The large open cells of the central portion of the shaft, characteristic of these spines, are not a common feature among
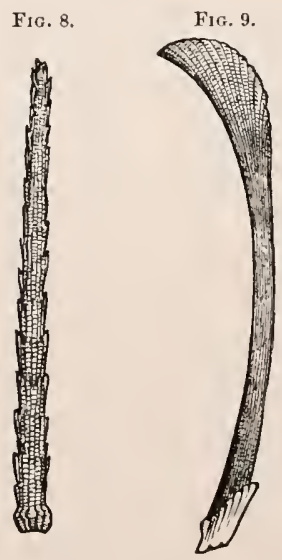

Fig. 10 .

FIG. 12.

IG. 11.
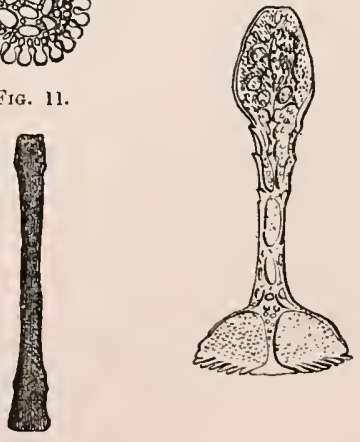

Spatangoids, where the central space is generally hollow ; these large cells reeall the structure of the central part of the spine in Dialematidae and in Arbaciadae. The miliaries carry minute silk-like spines of similar structure with the larger ones; and either large pedicellaria, with rather stont stems (Fig. 11) and large heads (Fig. 12), similar to those of Spatangus proper, or 
shorter-stemmed pedicellaria with a smaller head ; the latter occur over the whole of the actinal and abactinal part of the test; the former are found mainly in the broad, bare, posterior, actinal ambulacral avennes.

The anal system is curcular, covered by irregularly concentric plates, diminishing in size towards the anal opening; they carry secondary tubereles. Anal opening nearly central, slightly protruling. The ambulacral tubes of the petaloid portion of the ambulacra are lobed (Fig. 13). The tubes of the phyllodes resemble those of Echinocardium, terminating in club-shaped processes (Fig. 14), strengthened by simple, curved, limestone rods. In the base of the tubes the spicules are, as in all Spatangoids, most irregular in shape (Fig. 15). The details here given show the correctness of the views of D'Orbigny and Cottean regarding the affinities of Asterostoma. Agassiz, in the Catalogue Raisonné, leaves its position

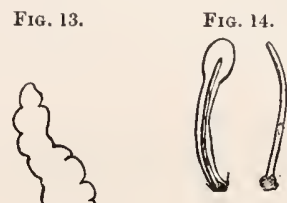

FIG. 15.

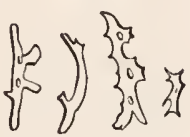
doubtful, though acknowledging the affinities with Ananchytes, and places it temporarily with the Cassidulidae. Desor, in his Synopsis, places the genus among the Galeritidae, near Pachyclypeus. The genus Asterostoma is known as a fossil from Cuba, and it is interesting that its nearest ally should have come from the Barbadoes.

100 fathoms, off Barbadoes.

\section{(SPATANGUS). Nacospatangus.}

Nacospatangus A. AG., 1873, Bull. M. C. Z., III. p. 189.

This subgenus is intermediate between Maretia and Micraster. The abactinal part of the anterior poriferous zone of the anterior lateral ambulacra is obliterated; what there is left of the anterior zone is reduced to simple pores, as in the extension of the zone beyond the petals towards the actinal surface in Spatangoids generally. Agassizia is the only Spatangoid genus in which the anterior zone is wanting, though in many Spatangoid genera- Echinocardium, Lovenia, Spatangus, Maretia - the abactinal part of the petals of the lateral ambulacra is more or less rudimentary or irregular. The lateral posterior ambulacra resemble those of Maretia. The anal extremity of the test is that of Spatangus proper. The tubercnlation of the test, as in Micraster, 
consists of uniform tubercles, slightly larger towards the ambitns, and towards the edge of the actinal part of the ambulacra. Distinct subanal fasciole, with rudimentary anal branches. General facies that of Nicraster, also of the high test species of Maretia and Spatangus. Ambulacra flush with the test; poriferous zones of the petals slightly sunken. Spines of the abactinal surface curved at the base, short, rather stout for a Spatangoid, of uniform length. On the abactinal surfice they inerease in length according to the prominence of the tubereulation.

\section{Nacospatangus gracilis}

! Nacospatangus gracilis A. AG., 1873, Bull. M. C. Z., III. P. 189.

$$
\text { Pl. II.f. } 3-5 \text {. }
$$

Test thin, seen from above elliptical, rounderl anteriorly, slightly angular laterally, tapering towarcls the posterior extremity, which is truncated. In profile the anterior extremity arches regnlarly towards the vertex, which is posterior, half-way between the apieal system am the nearly vertical anal extremity. The anal system is transversely elliptical, eovered by two onter concentric rows of larger plates, each earrying one or two minute secondary tuhercles, with smaller ones round the central anal opening. Nearly on the same vertical plane with the anal system, sloping slightly towards the actinostome, is situated the large subanal plastron. This terminates in a beak at the junction with the keel of the actimal plastron, and is edged with a distinct narrow fasciole, sending an indistinct rudimentary branch from the rounded anal extremity of the plastron, parallel with the anal system. The actimal plistron is narow, elongate, keeled, flanked by broad bare ambulacral avenues. The mouth is large, transrerse, with a prominent posterior lip. The tubereles of the actinal surfice are largest on the edges of the ambulacral avenues, diminishing in size towards the ambitus, where they gradually pass into the nearly uniform tubercles of the abactinal surface. The spines are silver-gray, rather stont, curved at the base; they cover thickly the whole abactimal surface; they are longer on the actimal side, according to the size of the tubereles, and largest on the edge of the ambulacral avenues. Miliaries and secondaries distant, irregularly scattered between the primaries; on the abretinal surface less numerons towards the ambitus. The apical system is anterior; three large genital openings placed close together; right anterior one wanting. The median interporiferons zone of the odd ambula- 
crum is thickly covered by secondaries and small miliaries. The anterior pair of petals, although shorter than the posterior, extends nearer the elge of the test.

In small specimens, not measuring more than $4.5^{\mathrm{mm}}$, the test is more eylindrical ; the ambulacra are not yet petaloid, but, as in young Spatangrus, the poriferons zones are diverging, composed of simple disconnected (fignred on Pl. Y If. f. 19, Rev. Ech.) pairs of pores; the abactinal part of the anterior zone of the anterior lateril ambulacra is already obliterated. The posterior patir of petals are first formed, by the spreading of the zones, due to the increase in wilth of the interporiferons space. This occurs while the pores are still simple, and somewhat later in specimens about a third $\left(6^{\mathrm{mur}}\right)$ the length of the one figured ; the pores of the petals separate and become conjugated, and form the petaloid portion of the ambulacra.

Off Juan Fernandez; 65 fathoms.

\section{Lovenia cordiformis}

! Lovenia cordiformis LüтK. MS., 1872, in A. AG, Bull. M. C. Z., III.

A broken specimen of this species was presented to the IIassler Expedition by Mrs. William Knapp of San Diego; it enables me to arld a few points to the imperfect description given in the Revision of the Echini. This species is, when compared with L. elongata, remarkable for its shallow and narrow anterior ambulacral groove, the elongate internal fasciole, the large size and proximity of the genital openings, but more especially for the narrow field of large secondary tubereles tlanking the apieal part of the odd ambulacrmm between it and the internal fasciole. The internal ponehes of the tribereles in the lateral interambulacra are much smaller and more closely packed than in specimens of the same size of L. elongatia. This species is more closely allied to L. elongata than to L. subcarinatin, to judge from the fragments of the posterior extremity in my possession.

San Diego ; California.

\section{Agassizia excentrica}

I Agassizia excentrica A. AG., 1869, Bull. M. C. Z., I. p. 276.

On Pl. XIV.f. 9-12 of the Revision of the Echini, I identified as the young of Agassizia a small Spatangoid; this was done with comsiderable hesitation, on account of the extreme flatness of the test, differing from 
the earlier stages known of other Spatangoids, when the test is more or less cylindrical. Quite a gool series of specimens of $A$ gassizia was dredged at Barbadoes, and in Lat. $37^{\circ}$, South ; Long. $56^{\circ}$, W est. The smallest speeimens were nearly as small as the presumed Agassizia of $I \%$. XIY., but agreed so entirely, except in size, with the larger specimens of Agassizia figured on $I \% . X I^{f} \cdot f \cdot 2,24$, Rev. Ech., that I am convinced the figure of the presumed Agassizia ( $P$. XIV. $f .9-12$ ) is the young of sone unknown Spatangoid.

In the smallest specimen the course of the fascioles was illentical with that of the older specimens; the outline of the test from above and in profile did not differ materially from that of the larger specimens; the test was somewhat less gibbous, and the posterior lateral ambulacra shorter, scarcely a quarter the length of the lateral anterior ambulacra. As in young Brissopsis the suekers of the odd ambulacrum, within the fasciole, early attain a very large size

Off Barbadoes, 100 fathoms. Lat. $37^{\circ} 42^{\prime}$, South ; Long. $56^{\circ} 20^{\prime}$, W'st. 44 fatboms.

\section{Agassizia scrobiculata}

! Agassizia scrobiculata VAL., 1846, Voyage Vénus.

Fragments of this species from Juan Fernandez in 220 fathoms. From the same spot imperfect specimens of a speeies of Brissopsis, remarkable for its elongated, narrow anal fisciole, which is very distinct and continuons from the subanal plastron to the peripetalons fisciole, thus differing strikingly from the anal fisciole of Brissopsis lyrifera.

\section{Hemiaster Philippii}

! Abatus Philippii LovÉn MS

I Hemiaster Philipüi A. AG., 1873, Bull. M C'. Z., III. No. 8, p. 189.

$$
\text { I'l. IV.f. 4-8. }
$$

I owe to Professor Lovén a specimen of this species, collected by Kinberg off La Plata. It was not includer in the Synonyny of the Revision, thinking Professor Irovén would soon describe it with other material he had in liand at the time of ny visit to Stockholun. Although Lovén only possessed a few quite young specimens, intermediate between the stages of $P l . I V . f . \tau, s$, yet, with his usual acumen, he correctly distinguished this species from its close ally, Ifemiaster australis.

A remarkably fine series of Hemiaster Philippii was collected by the 
Hassler Expedition on the Patagonian coast. It is extremely interesting, as it is the only Spatangoid, with rleeply sunken ambulacra, of which we know thus far anything of its development. The figures given on $I ' l . I V \cdot f \cdot q_{-}-8$ are all natural size, and show the changes the lateral ambulacra undergo as they pass from Fig. $s$ to Fig. $\%$, and from Fig. 6 to Fig. 4. When the specimens reach the size of Fig. 7 the ehange from eomparatively shallow lateral ambulacra to the deep ambulacra of Fig. 6 takes place without a great increase in the size of the test. The anterior ambulacra, eventually the most concave (Fig. 4), are the first to slow marked signs of depressions, and in slightly oller specimens than Fig. $y$ or Fig. 6 they are already deeply sunken, while the posterior lateral ambulacra are comparatively shallow. In most of the specimens examined I have found large, globular, short-stemmed pedicellarix situated in the sunken ambulacral petals, nsually the anterior pair, as mentioned by Philippi. Owing to the comparatively long spines of the edge of the petals, the sunken ambulacra are completely liidden by a sereen of spines. The changes of outline of the test are very limited, after the specimens have attained the size figured on $P l . I V . f . s$. The outline of the test is somewhat more angular and gibloous, seen from above, and perhaps less conical and somewhat more flattened at the apical system. Thre number of genital pores is variable, as we find two or three quite indifferently; the posterior pair of genital openings is always present; if a third exists it is the right anterior one, usually, but sometimes the left. In the youngest specimen figured the outline of the peripetalous faseiole is nearly the same as in the oldest specimen examined (Fig. 4), though its breadth becomes greater with advancing age. The odd anterior ambulacrum increases but little in depth and breadth with increasing size.

The color of the spines becomes somewhat darker in older specimens; they are in small specimens (Figs. 7,8 ) of a dirty yellow in alcohol.

The changes traced in this species will do much towards simplifying the aftinities of the many fossil speeies of Hemiaster and allied genera, which have frequently heen distinguished on very slight grounds, - the range of the changes shown to be possible in one species being far greater than distinetions which have served as generic features among allied fossil Spatangoids.

Hemiaster Philippii is distinguished from A. australis by its short posterior lateral ambulacral petals and its narrow peripetalous fasciole. Judging from the analogy of this species, $H$. australis and $H$. cavemosus may turn ont to 
be different stages of growth; H. australis corresponding to the younger stages of II. cavernosus, with its deeply sunken lateral ambulacra. Unfortumately sufficient material is not available to settle this question, as the species of IIemiaster from South America are extremely rare in the collections I have examined. Very small speeimens of II. Philippii are quite eylindrical (.75 mm. in length $)$; they go through changes of form very similar to those described in the growth of lirisopsis up to the youngest stages figured here, when the gradual sinking of the ambulacral petals comnences.

Lat. $37^{\circ} 42^{\prime}$, South; Long. $56^{\circ} 20^{\prime}$, West. 44 fathoms.

Lat $51^{\circ} 26^{\prime}$, South ; Long. $68^{\circ} 5^{\prime}$, West. 55 fathoms.

Off Cape Dus Bahias (East Coast Patagonia). 55 fathoms.

\section{Hemiaster cavernosus}

! Tripylus cavernosus Pril., 1845, Wieg. Archiv.

: Hemiester cavernosus A. Ag., 1872, Rev. Leh., PI. I. p. 132.

One large speeimen collected at Port Gallant.

\section{Tripylus excavatus}

! Tripylus excavatus Puil., 1845, Wieg. Arch.

With the sonthermmost specimens of Agassizia excentrica were colleeted a couple of small Spatangoids, which I am unable to rletermine satisfictorily. They resemble, in general outline and appearance, Agassizia, but without having the characteristic structure of the anterior lateral ambulacra of that genus; the course of the peripetaluns and lateral fiseioles is the same, as well as the general proportions of the ambulateral petals.

The changes undergone during growth in Ifemiaster Philippii, which have been deseribed above, seem to point to the probability of these small Spatangoids being the young of Tripylus excavatus. They have all the structural features of the genus, except the deeply sunken lateral ambulacra. The largest specimen, measuring about $7^{\text {mum }}$ long. diam., differed from the sualler one by having slightly longer posterior lateral petaloid ambulacra, already slightly depressed; while in the younger specimen the lateral ambulacia were thush with the test, as in Agassizia, and in the young of II. Philippii. It seems probable, therefore, that in genera with depressed or deeply sunken petals the young have, in their earlier stages, petaloil ambulacra flush with the test. In Schizaster canaliferus the lateral posterior ambulacra are but slightly sunken, even in the largest speeimens, while the anterior anbulaera 
are deeply concave. The separation, therefore, of Sehizaster and allied genera as a separate fimily from the Brissina, as has frequently been proposed, on account of the structure of the sunken petals, is not warranted, as this feature is evidently of very secondary importance. So that it seems even doubtful whether the genus Tripylus, as I have hinted in the Revision of the Echini, should be distinguished from Schizaster proper, and whether Schizaster, Tripylus, Hemiaster, Brissopsis, should not be considered as subgenera of one genus. At any rate, the relationship of such apparently widely separated forms as Schizaster, Linthia, Tripylus, Hemiaster, Faorina, and Rhynobrissus is very elose.

Lat. $377^{\circ} 42^{\prime}$, South; Long. $56^{\circ} 20^{\prime}$, W'est. 


\section{EXPLANATION OF THE PLATES.}

\section{PL $\Lambda$ TE I.}

1, 2. Astropyga pulvinata, two thirds natural size.

3, 4. Arbacia Dufresuii, natural size.

$5-7$. Coelopleurus floridanus, -5 , natural size ; 6,7 , four times natural size.

\section{I' L A T E I I.}

1, 2. Asthenosoma hystrix, two thirls natural size.

3-5. Nacospatangus gracilis, natural size, $17^{\mathrm{mm}}$.

6. Echinus margaritaceus, natural size.

\section{P L $\Lambda$ T E I I I.}

1-3. Monophora Darwinii, natural size.

4. Echinus margaritaceus, natural size.

5. Echinus magellanicus, natural size.

\section{PL $\Lambda$ T E I V.}

1-3. Paleopneustes cristatus, two thirls natural size.

4-8. Hemiaster Philippii, natural size. 

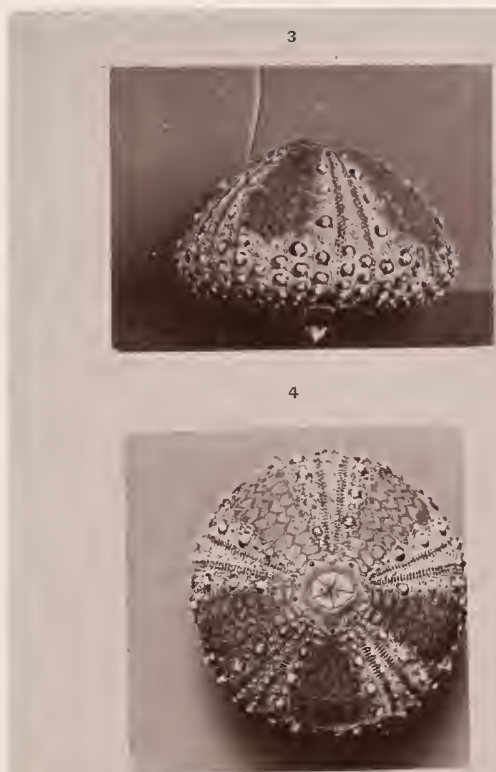

5
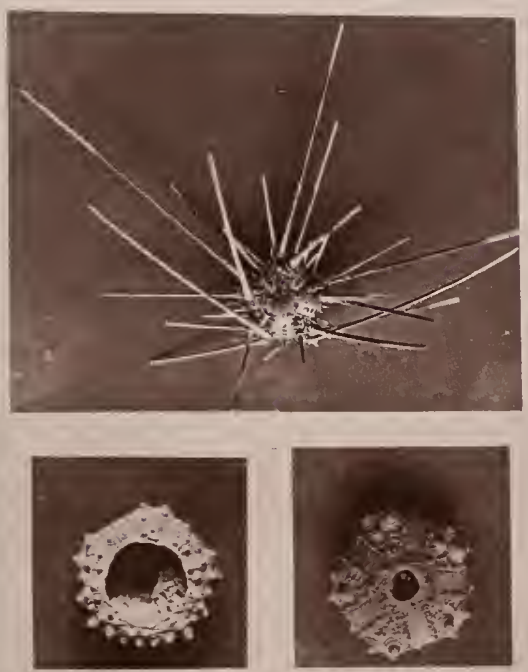

6

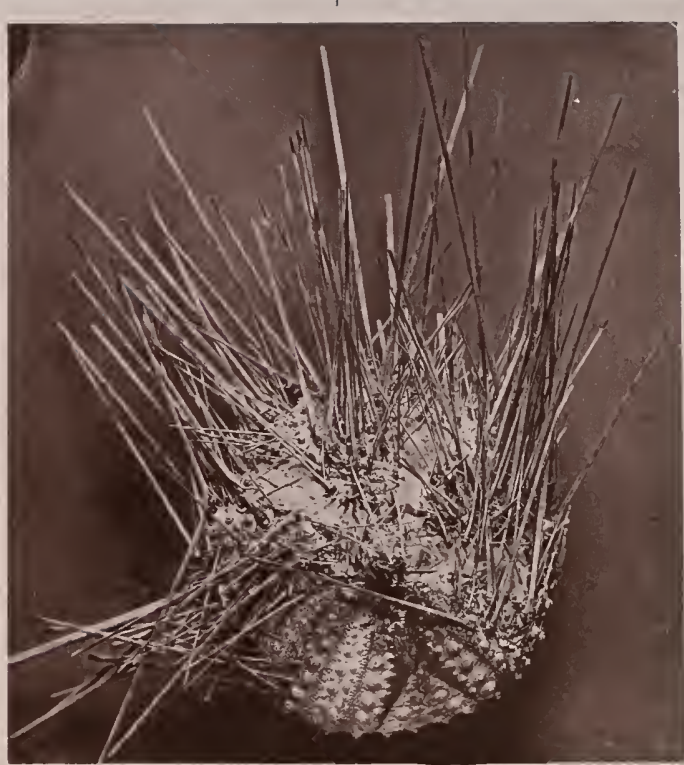

2

j).

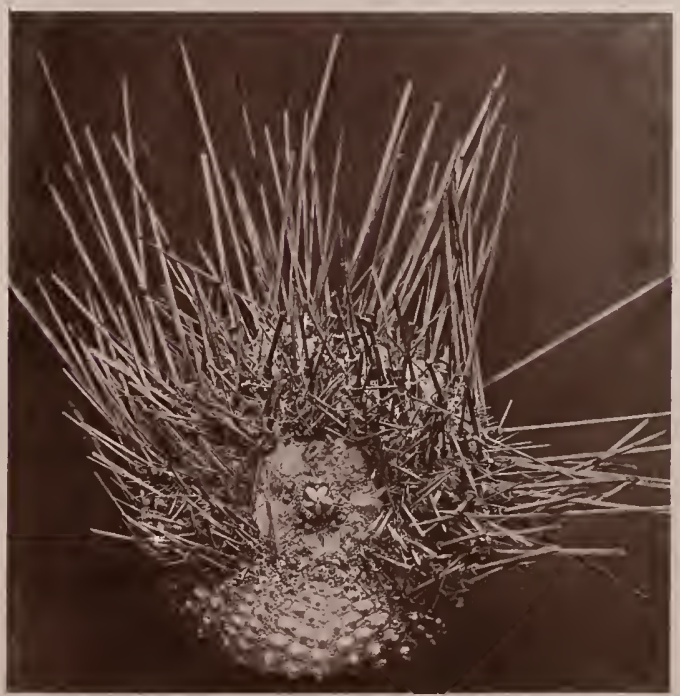

Heliotype. 


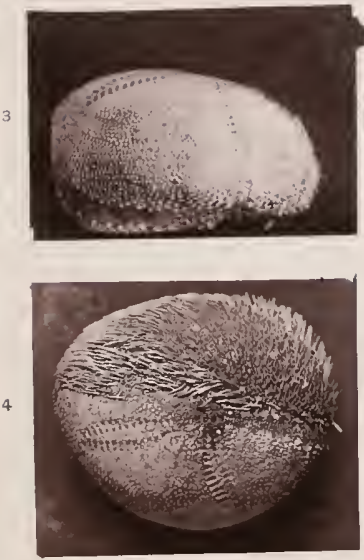

5
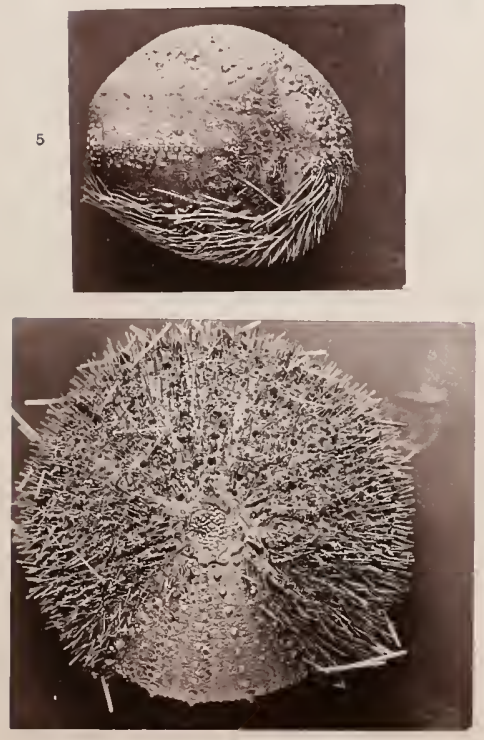

A. SONREL, Phetog.

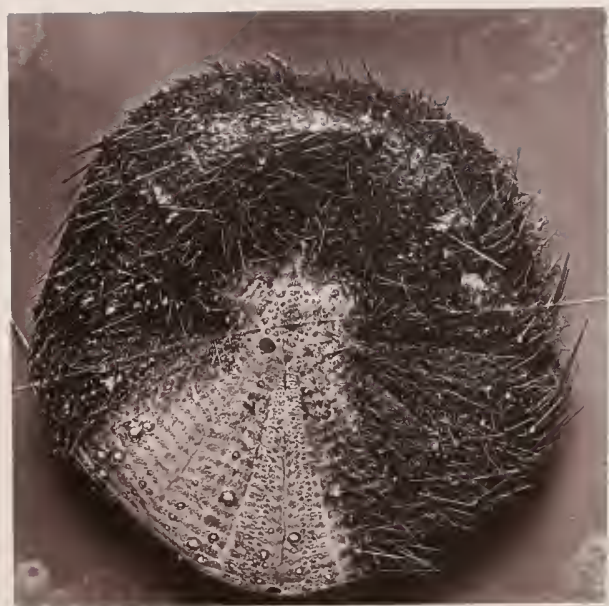

2

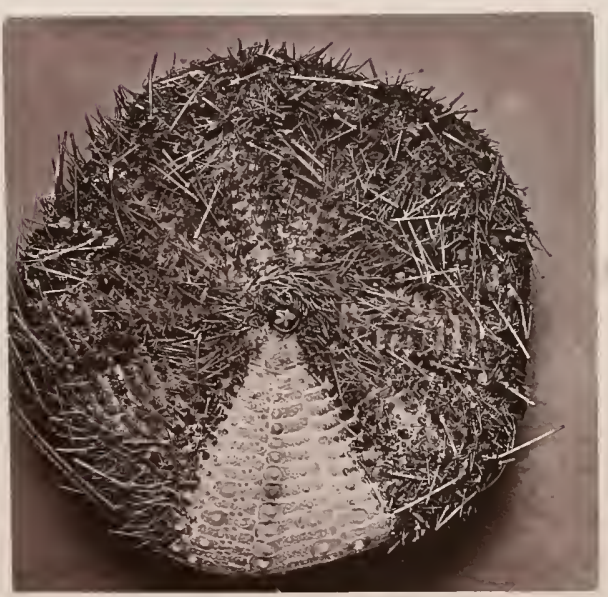

Fieliolype. 


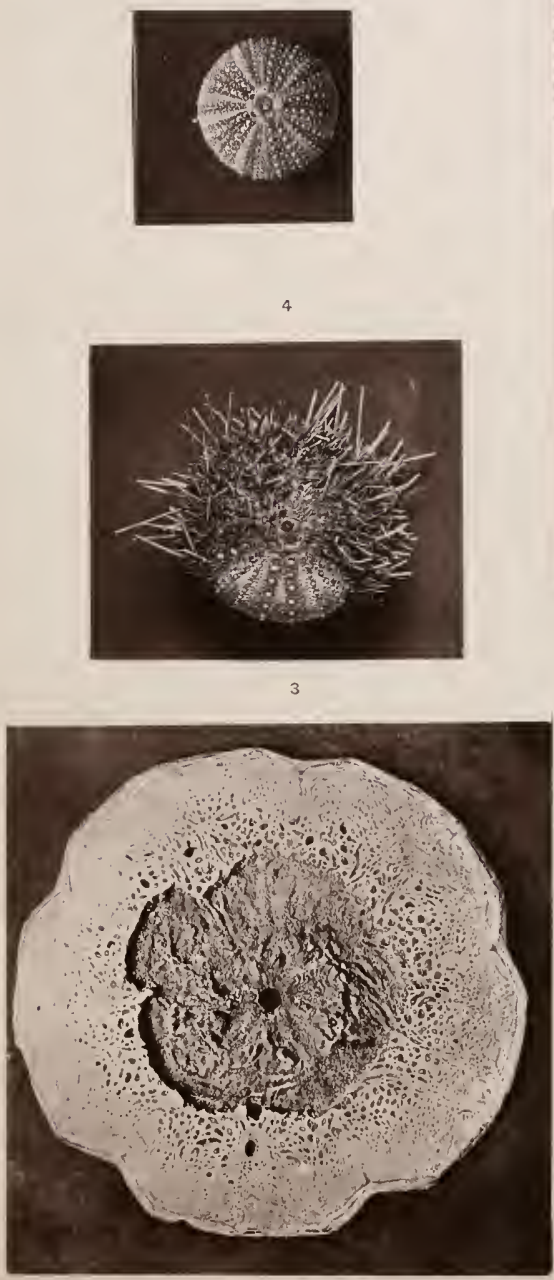

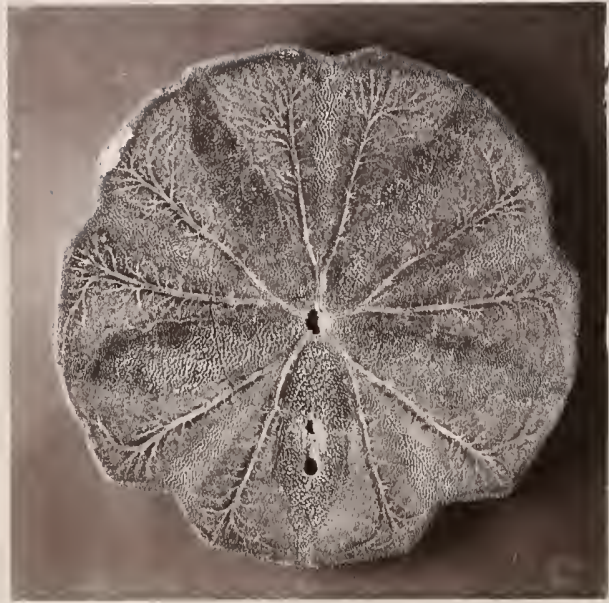

2

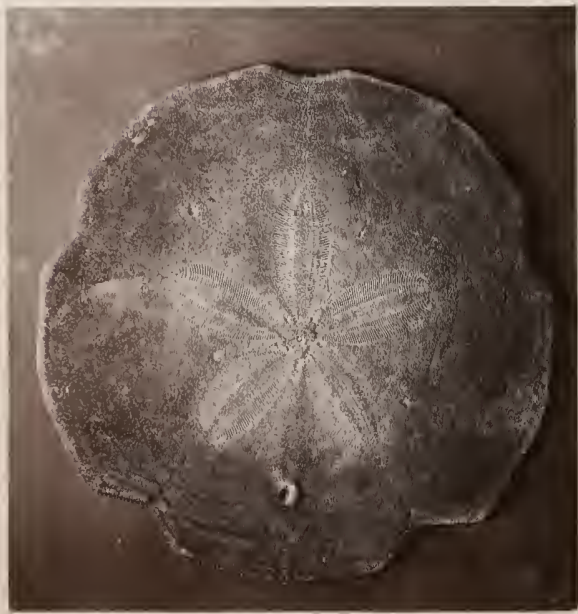




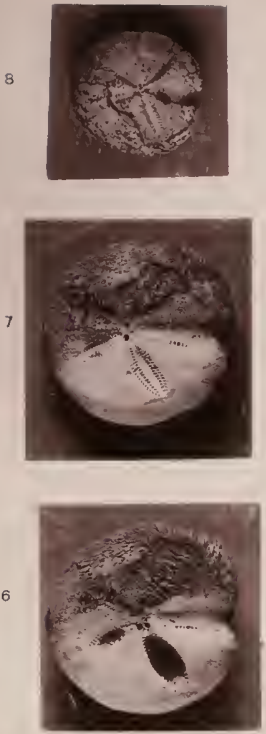

4

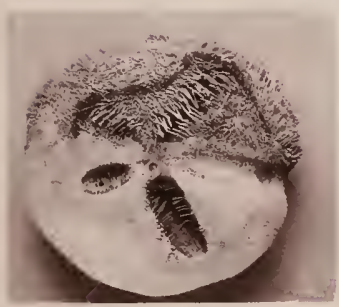

6

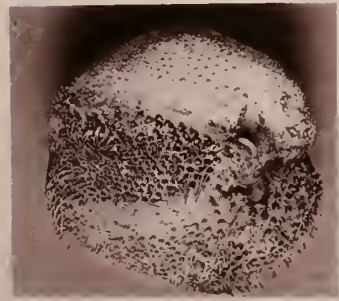

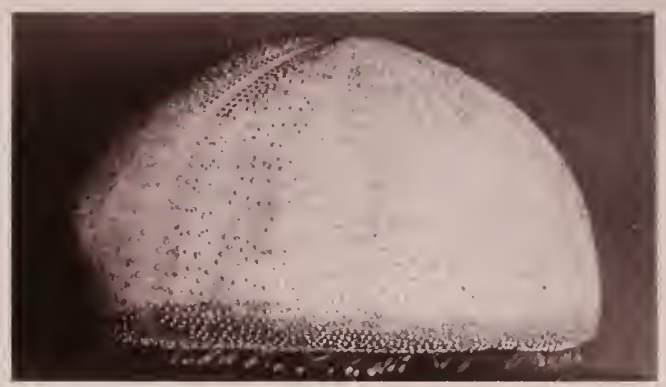

2
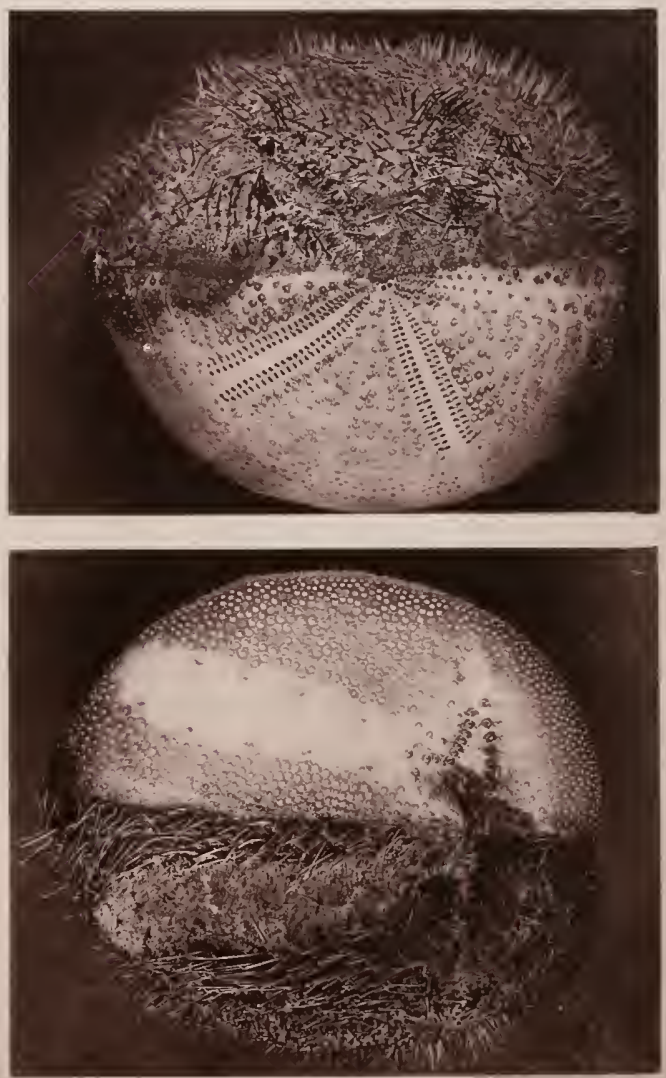



\title{
ZOÖLOGICAL RESULTS
}

UF

\section{THE IISSLER EXPEDITION.}

PUBLISIED BY PERMISSION OF PROF. B. PEIRCE, SUP'T OF THE U. S. COAST SURVEY.

\section{CRINOIDS AND-CORALS.}

\author{
BY L. F. JE POURTALÈS.
}





\section{ON A NEW SPECIES OF RIIZOCRINUS FROI BARBADOS.}

During the expedition of the U. S. steamer Hassler, several rich dredgings were obtained in depths varying from 80 to 120 fathoms, on the western coast of the island of Barbados, a few miles north of Bridgetown. The bottom was chiefly limestone sand, with rocky patehes, and very rich in deepsea corals, echinoderms, ete. It is a well-known locality for Pentacrinus asterias and Mulleri, and the second specimen of Holopus Rangii D'Orb. known to science, in the possession of Governor Rawson of Barbarlos, was brought up on a fishermau's hook in the same vicinity. We had not the luck to find either of these, though numerous joints of the stem of Pentacrinus were contained in the sand, but, in compensation, several living specimens of a Rhizocrinus, which were at first supposed to be large specimens of Rhizocrinns lofotensis Sars. A closer examination has proved them to be specifically distinct, and I take pleasure in dedicating the species to Governor Rawson W. Rawson, who was present at their capture, and whose hospitality rendered our short stay at Barbados so pleasant an epoch in the history of our voyage.

\section{Rhizocrinus Rawsonii Potrs.}

\section{Pl. V.f.1.}

Larger than R. lofotensis. The stem composed of joints proportionally shorter and more cylindrical than in that species, being seldom as much as two of their diameters in length, generally much less; the articulations are less elongated. The double articular excavation is larger and deeper (Fig. s). One specimen only was obtained with the root portion; it has the appearance of having been partly attached to a solid body by enlarged surfaces, and to have had very few radicular cirrhi (Fig. 2). This solid attachment to the bottom would explain why most of the specimens were broken off, whilst R. lofotensis, being generally planted in sand and fixed by ramifying rootlets, is easily brought up entire. 
The cup is proportionally more elongated than in the other species. It is composed of five rather long basals and the rather short first radials (Fig. 4). These ten pieces are solidly connected, but the joints are always plainly visible with a lens of moderate power, as they are also in R. lofotensis. The second radial is short and nearly square (Figs. 4, 5$)$. The third is largest and somewhat broader at its distal end. The four first brachials are equal in size to the radials, scuare, broad, flattened ont at the sides, and apparently united in pairs by syzygial joints (F'ig. $\gamma$ ). They contribute with the radials in forming the supports of the visceral cavity; the peristome being on the same level with and attached to the distal end of the fourth brachial (Figs. 1, $\gamma$ ), whilst in R. lofotensis it is fastened to the third radial. There is in no part of the arm a sudden narrowing down, as in the first brachial of R. lofotensis represented in Fig. 8 . The first pinnule arises from the fourth brachial. The arm-joints are very short, broader than long, every other joint being a syzygium. They are not as deeply emarginated for the insertion of the pimules as in the other species (Fig. 7 ).

There are from fourteen to twenty-two pinnules (Figs. $9-12)$ a side on each arm, the two first joints of which are considerably larger than the following, which decrease regularly in size to the tip; the lateral scales are much smaller than in the other species, where they are largest in the middle of the pinnule, thus giving it a long lanceolate appearance (Fig. 1.3).

The month is central, somewhat elongated in a direction at right angles with the diameter passing through the anus. The angles of the mouth are provided with hard lanceolate papilla, as in the species described by Sars. The anus is large, more oval than round, and somewhat bulging without being tubular (Fig. 14).

The largest specimen obtained measures $17 \mathrm{c.m}$. in height without the arms, and was originally longer, since the root is wanting. The dianeter of the stem is 1.5 to $2.0 \mathrm{~mm}$. It is composed of sixty-three joints.

The color is whitish and the surface clean. The skin I mentioned in the description of R. lofotensis (under the name of Bourgueticrinus Hotessieri) in No. 7 of the Bulletin of the Museum of Comparative Zoölogy, I have since found on closer examination to be a parasitic growth of a hydroid polyp.

I have mentioned above that the solid part of the cup or calice is formed by the union of the basals and first radials. Sars, in his description of Rhizocrinus lofotensis, strangely enough considers the lower portion as formed by an enlarged joint of the stem, in the same manner as in some of the fossil 
Apiocrinida. But in these the basal pieces are always visible on the outside, forming a ring between the enlarged joint and the first radials. In the young Comatula, when still attached to a stem, the formation of the cup is almost identical with that of Rhizocrinus. To render the proof still more conclusive, I forced a needle through the central hole of the calice of a Rhizocrinus lofotensis until it split. The fractures followed the joints between contiguous basals and between the latter and the first radials.

I copy from Professor Agassiz's note-book some observations he made upon the species described above, while specimens of it were kept alive on deck:-

"The next haul gave us a Crinoid very much like the Rhizocrinus lofotensis, but prolably different. We hat the Crinoid alive for ten or twelve hours. When contracted the pinules are pressed against the arms, and the arms themselves shut against one another, so that the whole looks like a brush male up of a few long coarse twines. When the animal opens, the arms at first separate without bending outside, so that the whole looks like an inverted pentapod; but gradually the tip of the arms hends ontward as the arms diverge more and more, and when' fully expanded the crown has the appearance of a lily of the Lilium Martagon type, in which each petal is curved upon itself, the pimmles of the arms sprearling laterally more and more as the crowu is more fully open. I luave not been able to detect any motion in the stem tracealle to contraction, though there is no stiffness in its bearing. When disturbed, the pinnules of the arms first contract, the arms straighten themselves out, and the whole gradually and slowly eloses up. It was a very impressive sight for me to watch the movements of this creature, for it told not of its own way only, but at the same time afforded a glimpse into the countless ages of the past, when these Crinoids, so rare and so rarely seen nowadays, formed a prominent feature of the animal kinglon. I could see, without great effort of the imagination, the shoal of Lockport teeming witl the many genera of Crinoids, which the geologists of New York bave rescuel from that prolific silurian deposit, or recall the formation of my native country, in the hillsiles of which, also among fossils indicating shoal water-beds, other Crinoids abound, resembling still more closely those we find in these waters. And now the question may be asked, What is the meaning of the occurrence of these animals in deep waters at the present day, when in former ages similar types inhabited shallow seas? Of the fact there can be no donbt; for it is not difficult to advance satisfactory evidence of the shoal-like character of the silurian deposits of the State of New York: their horizontal position, combined with the gradual recession of the higher beds in a sontherly direction, leaves no doubt upon this point ; and in the case of the Jurassic formation alluded to above, their combination with fossils common upon coral reefs and their presence in athols of that period are satisfactory proofs of my assertion. What does it then mean when we find the Pentacrinus and Rhizocrinus of the West Indies in deep waters only? It seems to me there is but one explanation for the fact, and that in the 
progress of the eartli's growth we must look to snch a displacement of the conditions favorable to the maintenance of certain lower types, as may recall most fully tle adaptations of former ages; and it was in this sense I alluded, in my first letter to the Superintendent of the United States Coast Survey, to the probability of our finding in deeper waters representatives of earlier geological types. If my explanation is correct, my antieipation is also fully sustained. But do the leep waters of the present condition of our globe really approximate the conditions for the development of animal life of the shoaler seas of jast geological ages? I think they lo so; at least they come as near to it as anything can in the present orler of things njon earth; since depth in the ocean alone ean place animals under conditions similar to those produced by the high pressure which the heavy atmosphere of earlier perious afforded."

Conceming the geographical distribution of this species we know, of course, nothing yet. All the specimens from Florida in the Museum of Comparative Zoilogy belong to R. lofotensis, which, from what we know from various explorations, inhabits a large portion of the North Atlantic. It is worthy of remank that all the Florida specimens dredged by me are regularly fivearmed. It is well known that a large proportion of those obtained on the coast of Norway by Sars were either four or six armed.

The fossil from Guadaloupe, on which D'Orbigny has founded his species of Bourgueticrinus Hotessieri, consists of a fragment of stem composed of six cylindrical joints. If they originally belonged to a Rhizocrinus, they could be only the joints immediately helow the eup, which are the ones most recently formed. But in our Rhizocrinus a series of six joints of that shape are not formed in that situation; they become rapidly elongated and swelled out in the middle as we follow the stem downwards. Another difference is that the central hole is never as large as in D'Orbigny's figure.

Among the older fossil Crinoids, the nearest approach to Rhizocrinus can be found in Belemnocrinus, White, from the upper Burlington Limestone, Iowa. (Proc. Boston Nat. Hist. Soc., Vol. IX. p. 13.) I have had the opportunity to examine several specimens of $B$. typus and one of B. Whitei, in the rich collection made by Mr. Wachsmuth and lately acquired by the Museum of Comparative Zoülogy. The former species has a calicle resembling that of Rhizocrinus very closely; the second differs only by being more obese. I am satisfied that the five short basal pieces figured by $\mathrm{Mr}$. White have no existence, and am inclined to think he has mistaken for them the upper joint of the stem which is somewhat indented in its upper edge to fit the base of the calicle. Noreover, that articulation can be seen plainly in one or two 
specimens to be cremulated like any other of the stem articulations. Granting, then, the absence of those pieces and using the nomenclature I lave adopted for the Rhizocrinus, the five basal pieces of Belemnocrinus are formed precisely as in the former. The first radials, alternating with the basals, are larger in Belemnocrinus, and are movable, whilst they are fixed in Rhizocrinus. 'The next three joints are equal, and are properly brachials, and are followed by an axial forming the bifurcation for the ten arms. The stem has no resemblance to that of Rhizocrinus, being round or obscurely pentagonal, and the articulations crenulated. 


\section{EXPLANATION OF TIE PLATE.}

1. Rhizocrinus Rawsonil, without rooteportion of stem.

2. Stem of another specimen, with rooteportion.

3. Articulating surface of a joint of the stem.

4. Caliele, showing basals and first and second radials.

5. Uper surface of ealicle, with sccond radials.

6. Same, after removal of second radials.

7. Two arms, between them the peristome.

8. Arm of Rhizocrinus lofotensis.

9. Base of pinnule of $\mathbf{R}$. Rawsonit.

10. Pinnule of the same, dorsal view.

11. Same with base, more magnified.

12. Same, lateral view,

13. Pinnule of $\mathbf{R}$. lofotensis, lateral vlew.

14. Mouth and anus of R. Rawsonii. 
Hassler Expedition.

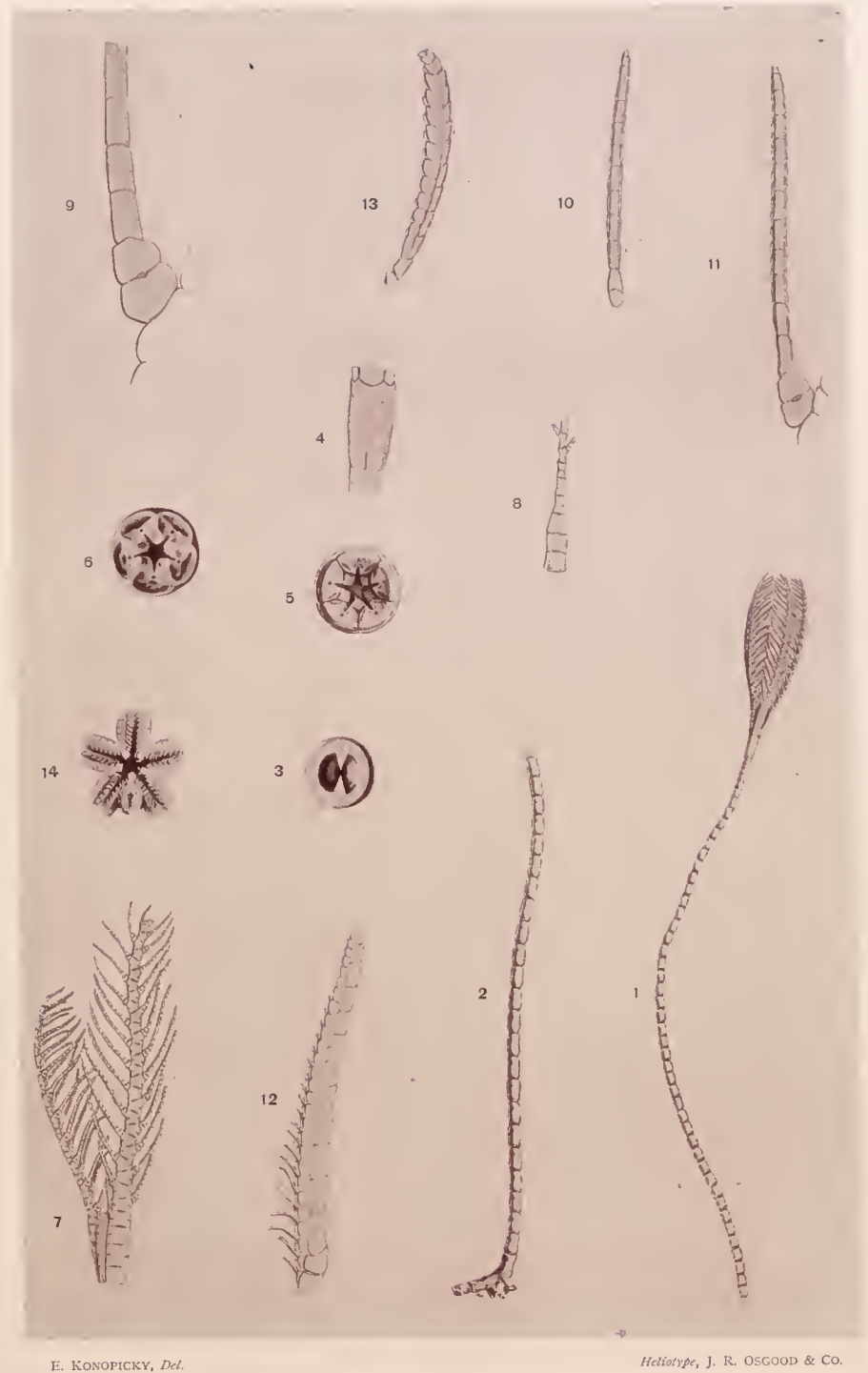





\section{DEEP-SEA CORALS.}

The deep-sea corals collected during the voyage of the United States steamer Hassler from Boston to San Francisco are not as nmmerous as were expected, varions causes having combined in rendering deep-sea drerlging rather unsuceessful. The only rich locality discovered was off the islund of Barbados, a few miles north of Bridgetown, in depths varying from 80 to 120 fathoms. A few corals of interest were also obtained off the coast of Brazil and off the island of Juan Fermandez.

The opportunity is taken in this paper to make some remarks on the deepsea corals dredged by the late Dr. W. Stimpson, during the last months of his life, in the waters of Florida, Cuba, and Yucatan, in the United States Coast Survey steamers Biblo and Bache.

\section{Family TURBINOLID仺 M.-Edw. \& H.}

CARYOPHYLLIA STOKES.

\section{Caryophyllia berteriana Decн.}

$$
\text { Pl. VI. figs. 1, 2. }
$$

About one hundred and twenty specimens of this species were dredged at Barbados in 100 fathoms. There is less variety of form in this than in any other species examined, and the development of the fifth cycle in two halfsystems at one end of the longitudinal axis manifests itself at an early age. There are, therefore, always fourteen pali, whilst $C$. formosa has never more than twelve. The fourth cycle is never incomplete as stated by M.Edwards and Haime. The specimen deseribed as C. berteriance in the Illustrated Catalogue of the Musemm of Comparative Zoölogy, No. IV., from the coast of Florida, I have now couvinced myself is only a variety of $C$. formosa 
with more exsert septa. Among the Barbados specimens there are a few with young ones growing from the wall which might readily be assigned to the genus Coenocyathus.

\section{Caryophyllia antillarum N. sp.}

$$
\text { Pl. TI. figs. 3, \&. }
$$

Corallum conical, with contracted base; costre granulated, distinet as firr down as the peduncle, flat and separated by fine linear ridges. Calicle cirenlar, or very slightly elliptical. Septa rather thick, moderately exsert, subequal, less densely granulated than in C. betteriana; the fourth cycle undeveloped in some of the systems, so as to give the gencral appearance of ten half-systems of three cycles, with ten pali. Columella papillar, of the type of $C$. cylindracea, not much developed. Height $2 \mathrm{~cm}$., diameter $12 \mathrm{~mm}$. It belongs to the same division of Caryophyllia as C. cylindracen, but differs from the latter by its thin pali, very unlike the thick pillar-like ones of the fossil species, - a character of which the European specimens described by Dr. Duncam seem all to partake more or less.

Barbados, 100 fathoms.

\section{BATHYCYATHUS M.-EDw. \& II.}

\section{Bathycyathus indicus M.-Eow. \& $\mathrm{H}$.}

A few specimens were dredged in 65 fathoms off the island of Juan Fernandez; being immature, they agree as well with the description of $B$. chilensis as with this one. It wonk not be surprising if the two species ultimately proved to be mere varieties of one and the same.

\section{Bathyeyathus maculatus x. sp.}

Pl. TI. figs. 5,6 .

Corallum attacherl by a large base, almost cylindrical when young, conical when old. Costa flat, distinct to the base, granulated. Fossa deep. Calicle subelliptical, the border nearly in one plane. Septa in six systems and five cycles. The primaries and secondaries subequal and somewhat exsert, spotted with brown. Twelve thin pali. Columella deep-seated and variable, composed in some cases of a large number of rather thick pillars, in others it 
might be called almost lamellar, the pillars being reduced to two or three flattened ones.

The size when full grown is about $2 \mathrm{~cm}$. high, and $18 \mathrm{~mm}$. in the greater riameter, the smaller being $14 \mathrm{~mm}$.

Off the Abrolhos, Brazil, in 30 fathoms.

\section{TROCHOCYATHUS M.-EDw, \& H.}

\section{Trochocyathus Rawsonii v. sp.}

\section{Pl. TI. figs. $7,8,9,10$.}

Corallum attached by a more or less expanded base, generally becoming very small in old specinens, short-conical, or cupshaped; without epitheca. Costre well marked, granulated. Calicle circular. Fossa moderately deep. Septa thin, slightly exsert, rounded, with surall sharp granules. Four cycles and sometimes a few septa of the fifth. Pali slender, sometimes lobed in front of the septa of the three first cycles, distant from the centre in proportion to the age of the cycle. Columella small, composed of five or six slender points loosely connected with one another.

Height S-10 mm., diameter $10-17 \mathrm{~mm}$. Dredger in 100 fathoms off Barbados, and also by Dr. Stimpson in the same depth on the west coast of Florida. The Florida specimens are generally more cupshaped and have a much smaller base of attachment than those from Barbados. They are also of a somewhat larger size at an average.

\section{DELTOCYATIIUS M.-EDW. \& H.}

\section{Deltocyathus Agassizii Puveт. \\ J'ar. calcar. Pl. TI. fig. 11.}

A considerable number of fine specimens, living and dead, were obtained off Barbados in 100 fathoms. All but one specimen belong to the wellmarked variety with spines on the primary costre, which 1 should not hesitate to consider as specifically distinct but for a few specimens which show intermediate characters. All the Babados specimens have the spines remarkably developed, an abnormal one having as many as three on each primary costa. Fresh specimens are prettily colored of a purplish brown, darkest on the secondary septa and next on the tertiary ones. The primary ones with the 
spines are either entirely white or only slightly colored. The pali and columella are generally white. but if somewhat colored the primary parts are darkest. One specimen is perfectly white with dark spines.

A few specimens were dredged by Dr. Stimpson in $413-424$ fithoms in the straits of Yucatan, and off the west coast of Florida in 100 fathoms; all of the spineless variety. He found again, as I had before, the two varieties off Havana in 270 fathoms.

Several broken specimens which have continued to live and modified their shape slightly quite agree with the fossils on which Philippi has based his genus Eemesus.

\section{SCHIZOCTATHUS N. G.}

Corallum simple, withont epitheca or costa; no columella; pali in front of the last cycle, united in front of the penultimate; propagating by internal gemmation.

\section{Schizocyathus fissilis N. sP.}

\section{Pl. IT. figs. 12, 13 .}

Corallum long, conical, almost cylindrical, smooth, marked outside by lines corresponding to the primary septa and by rows of dots corresponding to the interseptal chambers; the secondary and tertiary septa show no mark outside. Calicle circular, wall thin, fossa moderately deep. Septa not exsert, very little granulated, in six systems and three cycles. Primary septa almost rudimentary, secondary ones largest, those of the third cycle intimately united with a sort of pali which also unite completely in front of the secondary septa; the interior of the coral is thus divided into a number of chambers entirely separated from ench other, consisting of the interseptal chambers between the secondary and tertiary septa, sometimes united in pairs in front of the secondaries, but more commonly entirely separated by the union of the secondaries with the symphysis of the pali. Another eavity is the central star-shaped one representing the space which would be filled up by the primary septa if fully developed. All these cavities are, however, extremely narrow.

The propagation is carried out by budding inside the calicle, generally on the secondary septa. By the growth of the bud the parent is split along the lines marking the primary septa, and a strip comprising one or rarely two 
systems remains permanently attached to the new individual. Height 6 or $7 \mathrm{~mm}$., diameter $3 \mathrm{~mm}$ :

Barbados, 100 fathoms; not rare.

THECOCYATHUS M.-EDW. \& H.

Thecocyathus cylindraceus Potrr.

Off Barbados in 100 fathoms one specimen only was obtained. A dead specimen of a Thecocyathus, probably of that species, was dredged in 35 fathoms off Cape Frio, Brazil.

\section{SPHENOTROCIUS M.-EDW. \& H.}

\section{Sphenotrochus auritus N. SP.}

Pl. IT. figs. 14,15 .

Corallum wedge-shaped, with broad and thin base, having in the middle a small knob containing a grain of sand, and on each side a flat protuberance somewhat resembling that of Platytrochus, pointing downward, so that the base has a three-pointed appearance in perfectly formed specimens. In old specimens the outline becomes more irregular. The costre radiate on the sides from the central protuberance in the shape of a fan; they are formed by rows of flat tubercles or interrupted ridges, at first simple, then double, and finally treble or even quadruple near the calicle, ending by giving the outer edge of the septa a very crispate appearance. The angles of the base are covered with similar tubercles or granules irregularly. arranged or forming obscure lines diverging from the costie. Septa thick, with firlled edges and thickly covered with sharp granules, in six systems of three cycles. The lamellar columella is granulated like the septa. Height $9 \mathrm{~mm}$., breadth of base 4-5 mm., greater cliameter of calicle $7-\$$ mm., smaller diameter $4 \mathrm{~mm}$.

Several specimens, all dead, but perfect, were obtained off Cape Frio, Brazil, in 35 fathoms, sandy bottom.

A few specimens of a Sphenotrochus were dredged in 12-1S fathoms on the coast of Brazil in lat. $11^{\circ} 49^{\prime} \mathrm{S}$. which may belong to another species, or be the young of the above. They are much smaller, regularly conical and tlattened, but without lateral expansions, and the costa are formed of flat pavement-like tubercles. They are all somewhat worn. 


\section{PARACYATHUS M.-EDW. \& II. \\ Paracyathus De Filippii Iver. \& Мrсн.}

Paracyathus confertus Pourt.

The Paracyathus described by Duchassaing and Michelotti under the above name is undoubtedly a young one not fully developed, as the figure certainly shows. Having frequently found specimens answering as nearly to their figure and description as a comparison is possible, associated with the larger ones to which I have given the name of confertus, I suspect them to be one and the same.

The characters are very variable, the type figured in my "Deep-Sea Corals," Plate VI., Figs. 11, 12, 13, passing into another with deeply sunk columella, the papilla of which are partly twisted like those of a Caryophyllia or Trochocyathus, well-defined pali rising much higher, more exsert septa, and a more regular shape. This latter type is the most common at Barbados, the other in Florida. The great variability of these forms inclines me to believe that $P$. Algassizii Dunc. can scarcely be separated specifically from the West Indian form.

\section{DESMOPHYLLUM Eirkg.}

\section{Desmophyllum Cailleti Ducн. \& Miсн.}

This species appears to be common off Barbados in 100 fathoms. I have become convinced, by the examination of a series of specimens of different ages, that the coral deseribed hy me under the name of Galaxea ebumer (III. Cat. Mus. Comp. Zoöl., No. IV.) is only a young Desmophyllum, but of a species with thicker septa than $D$. Crilleti.

\section{FLABELLUM ILESON. \\ Flabellum braziliense N. sp.}

Pl. TI. figs. $16,1 \%$.

Corallum pedicellate, conical (greatest angle about $65^{\circ}$ ), compressed with rounded angles; costre prominent; fossa deep; calicle long, elliptical, diameters as 10 to 21 ; septa not exsert; five cycles, primaries, secondaries, and tertiaries nearly equal. A rudimentary lamellar columella. Height $16 \mathrm{~mm}$., 
greater diameter $18 \mathrm{~mm}$. One dead specimen dredged in 40 fathoms on the coast of Brazil, in lat. $11^{\circ} 49^{\prime} \mathrm{S}$.

The only Flabellum deseribed from the South Atlantic is F. Thouarsii M.-Elw. \& H., from the Falkland Islands, which has the coste much less developed.

\section{RHIZOTROCHUS M.-EDw. \& H.}

\section{Rhizotrochus tulipa x. sp.}

$$
\text { Pl. VT. figs. 18, } 19 .
$$

Corallum conical, pedunculated, coste barely convex; calicle subelliptical, fossa deep; septa thin, somewhat exsert, with very small tubercles in lines, the primaries and secondaries uniting deep down to form a false columella. The eolor of the wall is white, septa and coste a reddish-brown.

This species is closely allied to Rhizotrochus fragilis, but differs from it by its exsert septa, which in the latter never reach over the wall. It is also less open, and the septa are thinner and smoother. The root processes are the same. Rhizotrochus fragilis is generally white, rarely colored, and uniformly thin.

Off Barbados in 100 fathoms.

\section{Family TROCHOSMILID咂 IM.-Edw. \& H.}

CCENOSMILIA, N. G.

This genus is formed to receive the Parasmilia propagating by gemnation, and thus becoming compound. Single eorallites are typical Paramilie. I follow herein the example of Milne-Edwards and IIaime, though on a former occasion I have departed from it.

\section{Cœnosmilia arbuscula x. sp.}

$$
\text { 1\%. III. fig. } 1 \text {. }
$$

Corallum forming rather irregular clusters, though the rule appears to be that two corallites grow from the wall of the parent on opposite sides at a very open angle. The simple corallites are regularly conical. Coste better 
marked near the calicle than the base, finely serrate. Septa somewhat exsert, rounded, granulated, in four cycles not equally developed in all the systems. Calicle suboval, deep. Columella spongy, well developed. Endotheca not very abundant.

Barbados, 100 fathoms.

LOPHOSMILIA MI.-EDW. \& H.

Lophosmilia rotundifolia II.-Evw. \& $\mathrm{H}$.

Pl. VII. figs. 2, 3.

A fine coral dredged in Barbados agrees in every essential particular with the description of the above species, except in the columella, which is considerably thicker than in the figure of M.-Edwards and Haime, so that it scarcely deserves the name of lamellar, still it is much elongated and obscurely trilobed, so that it may be simply a variety. Duchassaing, in lis Revue des Zoophytes et des Spongiaires des Antilles, 1870, asserts that this species is only a young and still simple corallite of a compound genus which he has named Oxysmilia rotundifolic. The specimen in question is undonbtedly adult, and shows no signs of gemmation.

\section{Family STYLOPHORID压 M.-Edw. \& H.}

On re-examining the subject, it seems to me preferable to retain the generic name of Axohelia, which I had joined to Madracis, for the species with compact coenenchyma, and the latter name for those in which it remains cellular.

AXOHELIA M.-EDw. \& H.

Axohelia (Stylophora) dumetosa Ducr.

Pl. VIII. fig. 1.

To Duchassaing's description onght to be added that there are always ten equal septa, hence it is no Stylophora. The colmmella is pointed, and is hirsute as well as the septa. The branches are $S$ to $10 \mathrm{~cm}$. high, slender, 6 to $8 \mathrm{~mm}$. in diameter at the base. Color white with purple polyps.

Barbados, 100 fathoms. The Museum possesses also a specimen from St. Thomas, presented by Dr. Duchassaing, but without label. 
Fragments of an Axohelia were dredged off the coast of Brazil, in lat. $11^{\circ} 49^{\prime}$ S., 12 fathoms, which belong probably to this species also.

There are in the Museum specimens of three other species of Axohelia from the West Indies, one of which is very different from any described.* The two others are referred provisionally, the one to Axohelia myriaster M.Edw. \& H., Plate VIII. Fig. 3; the other to Axohelia mirabilis (Stylopteora mirabilis Duch. \& Mich.), Plate VIII. Fig. 4. The former is from IIavana, the second from Guadaloupe. Comparisons with type specimens are absolutely necessary to permit the names to be attached to them with certainty.

MADRACIS M.-EDW. \& H.

Madracis decactis VeRRILL.

Astreca decactis Lrman.

Stylophore incrustans DUCH. \& MICH.

Reusisin lamellosa Ducir. \& Micri.

Barbados, 100 fathoms. I have never found it in deep water in Florida, but only in depths less than 17 fathoms.

Madracis asperula M.-EDw. \& H.

Coast of Brazil in lat. $11^{\circ} 49^{\prime}$ S., 40 fithoms.

\section{Family ASTR止ID君 M.-Edw. \& H.}

\section{ANTILLIA DUNCAN.}

Reuss considers Cyathopleyllia From. as synonymons with Antillia, which is probably true, and gives preference to the former name. It is, however, an improper name, not differing enough from Cyathophyllum, and Antillia has besides the advantage of priority.

* Axohelia Schrammii n. sp. Plate VIII. Fig. 2. Slenderly branched, subflabellate, faintly striated; stria flat and broad, much interrupted and anastomosed, very rare small spines near the calicles of the ends of branches. Calicles prominent, somewhat less than one diameter apart; ten stout, smooth, very exsert septa; columella massive, tlat, somctimes with rudiments of a knob in the centre. The free part of the septa is $1 \mathrm{~mm}$. high. Guadaloupe. Received from M. Schramm. 


\section{Antillia explanata v. sp.}

$$
\text { Pl. VII. figs. 4, 5, } 6 \text {. }
$$

Corallum horizontally flattened, with almost horizontal base having a small area of attachment in the centre. Epitheea complete, wrinkled, concealing all trace of coste. Endotheca abundant and vesicular. Calicle oblong, somewhat irregular, shallow. Septa in five cycles with a few of the sixth; systems not readily distinguished, as the primaries, secondaries, and tertiaries are nearly equal. The septa are thin, ormamented with rows of very small, sharp tubercles; their border is divider in numerous branching spines, which in the younger septa anastomose so as to form a delicate network. Columelia well developed, formed of numerous twisted and tangled processes. Greatest diameter $4 \mathrm{~cm}$., lesser $3 \mathrm{~cm}$.; height a little over $1 \mathrm{~cm}$.

Barbados, 75 fathoms.

This is the first specimen of this extinet genus found living. Seen from above it is indistinguishable from a Lithophyllia, but its lower surface with its epitheea and small point of attachment immediately reveals the difference.

CLADOCORACE开 ML-EDW. \& H.

CLADOCORA MI.-EDW. \& H.

Cladocora patriarca v. SP.

Pl. VII. fig. \%.

Corallum forming from a parent corallite from which numerous younger ones grow at a very open angre, and remain smaller than the primitive one. Coste well marked, but not prominent, rather smooth. Fossa not as deep as usual in this genus. Septa very little serrated, scarcely exsert, in six unequal systems, the fourth eyele being developed in a few half-systems only. Pali much more developed than in most other species of this genus; pointed, fronting the septa of all but the last cycle, unequally distant from the eentre. Columella well developed, papillar.

Height $4-4.5 \mathrm{~cm}$; diameter of calicle $4-5 \mathrm{~mm}$. Depth of fossa $1 \mathrm{~mm}$. or less.

Off Cape Frio, Brazil, in 35 fathoms. 


\section{Family STYLASTERID咂 Gray. STYIASTER GraY. Stylaster punctatus Pơrr. Pl. I'll. figs. $s, 9$.}

(Fig. 9 is the typical specimen from the Straits of Florida.)

A slender variety of this species was dredged rather abundantly off Barbados in 100 fithoms. It differs from the typieal specimen by its more slender branches, and the color, which is orange-pink, whilst the other is purple.

\section{DIS'TICHOPORA LANK.}

\section{Distichopora barbadensis N. SP.}

\section{Pl. VII. fig. 10.}

Small, not much ramified, branches almost eylindrical, compressed at the end. Coenenchyina rather rough. Calicles not in a furrow, except slightly at the end of the branches. Interseptal pores tuberculated and in two nearly equal rows. Color pink with whitish tips.

Rather abundant in 100 fathoms, off Barbados.

Plate VII. fig. 11 represents Distichopora cervina Pourt. (Illust. Cat. Mus. Comp. Zoöl., No. IV., p. 39, note.)

\section{Family EUPSAMMID框 M.-Edw. \& H. \\ BALANOPHYLLIA SEarles Wood. Balanophyllia floridana Pourt.

$$
\text { Pl. Ir. fig. 20. }
$$

'Two small specimens dredgred off Barbados in 100 fathoms appear to belong to this species, thongh differing slightly in some particulars from the Florida form.

\section{Family FUNGID开 Dana. \\ FUNGIA LAMK. \\ Fungia symmetrica Pourt.}

Barbados, 100 fathoms. 
DIASERIS M.-EDW. \& H.

Diaseris crispa P'nст.

Barbados, 100 fathoms.

\section{MYCEDILII OKEN. \\ Mycedium cailleti Ducr. \& Micr. \\ Pl. IX figs. 1, 2.}

Barbados, 100 fathoms. A dead specimen.

\section{Order RUGOSA M.-Enw. \& H.}

It must remain as yet an open question if the arrangement of the septa in four systems instead of six is a criterion of the order of Rugosa. It is not unusual among the Stylina, which cannot well be placed here. For the present the two following genera are kept under this head.

\section{GUYNIA Duncan.}

\section{Guynia annulata Drxe.}

Pl. IX. figs. 3,4 .

The Barbados specimens differ very slightly from Dr. Duncan's figures in having the costre much less apparent. The attachment of one of the septa to the columella seems to be more the exception than the rule, at least I never find it in well-developed specimens with free calicle.

Barbados, 100 fathoms, rather abundant. A dozen specimens were foumd attached to a stone three inches in diameter.

\section{DUNCANIA N. G.}

Corallum attached, cylindrical, covered with a thick wrinkled epitheca rising over the border of the calicle. Interseptal ehambers filling up solidly from the bottom, a multiple pillared colmmella. Sometimes paliform lobes.

Differ's from Haplophyllia Pourt. (non Aplophyllia D’Orb.) by the formation of the columella. From 'Thecocyathus, with which it might be confounded by the general appearance, it is easily distinguished by its very different epitheca, and by the arrangement of the septa, which show no definite systems and no derivation from a primary hexameral division. 


\section{Duncania barbadensis $\mathrm{N}$. SP. \\ Pl. IX. figs. 5, 6, \% .}

Corallum cylindrical, obliquely attached, covered with a thick wrinkled epitheca, which rises above the margin of the calicle, and sends out folds on one side, which fasten to the body on which the coral grows. No coste discernible. Fossa circular, not deep. Septa not projecting above the edge formed by the epitheca, and leaving a concave border between their onter edge and the epitheca; rounded, rather thick, entire, with granulated surfaces. There are no distinct systems; the normal number of septa appears to be twenty, though there are sometimes one or two more or less; alternate ones are slightly smaller, and have one or two, sometimes three, paliform lobes little different from the columella.* Between these twenty principal septa which appear to belong to two cycles, there are rudimentary ones of a third, which mostly remain in the condition of flat ridges against the wall. Columella formed by a dense cluster of pillars, varying from ten to twenty in number. The interseptal chambers are not very deep, the whole interior of the coral being filled up solidly for nearly two thirds of the height; a vertical section shows no trace of separate tabule or dissepiments in the solid mass. All the specimens have a very oblique plane of attachment, so that, resting on a horizontal surface, the calicle stands at an angle of about $60^{\circ}$. The position of the longer diameter of the mouth of the polyp bears no constant relation to the inclination of the base.

The polyp is deep flesh-colored, and conformed exactly as in Iaplophyllia; the tentacles are about 25 or 30 in number, conical with inflated tips. The sphincter closing over the retracted tentacles is considerably above the mouth, and when contracted forms between the disk and mouth a well-rlefined prebuccal cavity, as it is called by Duchassaing.

Height $20-25 \mathrm{~mm}$., diameter $10-11 \mathrm{~mm}$. Several specimens were obtained in 100 fathoms off Barbados.

\footnotetext{
* The number of twenty septa is frequently found in the Staurida and Cyathaxonidx, where there are four systems with unequally developer cycles.
} 


\section{Suborder AN'TIPATHRAIA .-EDw. \& H.}

\section{Antipathes (Cirrhipathes) Desbonnii Decr. \& M Iсн.}

Our specimens are 50 to $55 \mathrm{~cm}$. long, but not much more than $1 \mathrm{~mm}$. in diameter at the base; densely covered with small spines. The polyps are of the type with long tentacles, are confined to one side of the stem, and seem to be alternately large and small.

Barbados, 100 fathoms.

\section{Antipathes (Arachnopathes) columnaris Ducusss.}

$$
\text { Pl. IX. fig. s. }
$$

The singular growth of this species deserves a few words in addition to Dr. Duchassaing's description. The stem is simple, the branchlets in verticils close together, themselves verticillate and occasionally biverticillate, coalescing oceasionally. Branchlets spinous, not nodose, the spines triangular and compressed, small. The central reticulate column mentioned by Duchassaing is hollow, and the habitation of an anuelid which appears to compel the corallum to form an abnormal growth of that shape. We see a similar action of parasitic annelids in some true corals, such as Lophohelia, Stylaster, Allopora, and others. Every one of the speeimens dredged was affeeted in that way, the annelid being still in place in most eases. The total height is 9 to $10 \mathrm{~cm}$. The polyps could not be observed.

Barbados, 100 fathoms.

\section{Antipathes humilis Pours.}

Pl. IX. fig. 9 .

A variety of this species was dredged off Barbados. It differs from the typical form from Cuba by its more simple and regular mode of branching. The short stem throws off on each side, at different heights, a simple branch forming a short curve and then growing parallel to the main stem. From the base of that branch auother sets off in the same mamer and in the same plane, and so on, so that the whole resembles certain fruit-trees trained on a wall. The Cuba specimens branch according to the same plan, but do not adhere to it so regularly. 


\section{Antipathes abietina N. sP.}

\section{IP. IX. fig. 10 .}

Stem simple, or emitting a few simple branches from the base, stiff, ereet, hirsute, beset with short, simple pimmules on all sides, not verticillate. This is the principal difference from A. filix, which is pinnate. Pinnules nodose, beset with cylindrical spines. Polyps of the type with short tentacles, surrounded by longer spines than those on the rest of the pinnule. Height $10 \mathrm{~cm}$. Pinnules about $1 \mathrm{~cm}$. long.

Every specimen has one or two worm-tubes attached to the stem, as in A. filix (see Bull. Mus. Comp. Zoöl., No. VI.).

Barbados, 100 fathoms.

\section{Antipathes lenta Pount.}

Barbados, 100 fathoms.

\section{Antipathes Fernandezii N. sP.}

Main stem unknown. Branchlets pinnate, with alternate and rather long pinnules. Densely hirsute with short spines disposed in longitudinal rows. Spines somewhat compressed and hooked upwards near the tip. Polyps elongated, with short tentacles, rather crowded on upper part of pinnules.

Ofl Juan Fermandez, in 65 and 220 fathoms.

The works of Milne-Edwards and Haime, Reuss, Duncan, Seguenza, and others, give us the means of making a comparison between the living IVest Indian coral fauma, both littoral and deep-water, and the fauna of the European tertiary formations. The resemblance between the two is a very striking one, as can be seen at a glance in the following table, where the genera common to both are enumerated, the living ones being separated according to their habitat in the littoral or the deep-sea zone. In a few cases the nearest allied genus has been taken as the representative of the extinct one. 


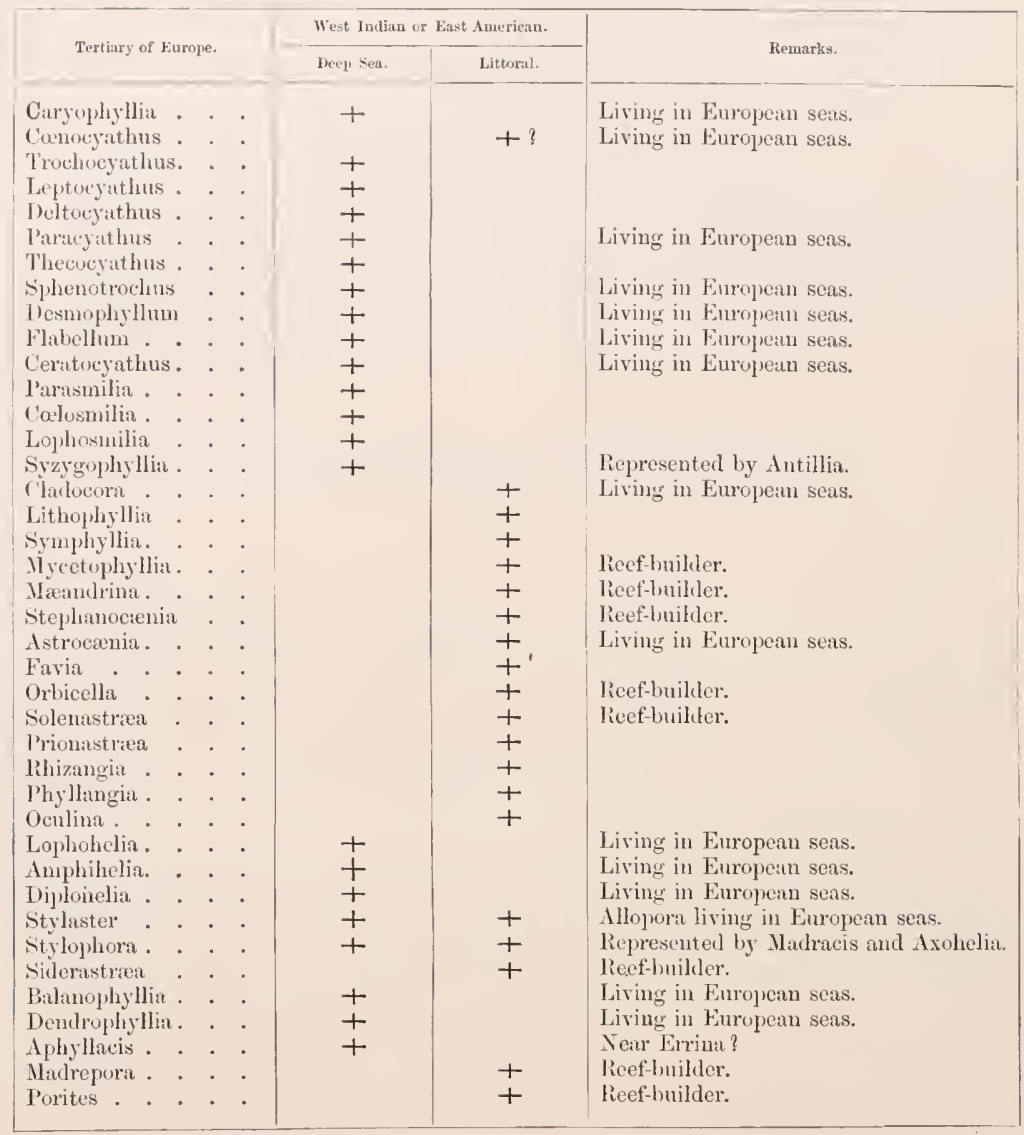

In comparing the tertiary fauna of the West Indies and the living of the same region, we find the list of genera common to both much smaller than the precenling one, as the following table, compilerl from Dr. Duncan's papers, will show. A few additions have been made, based on the examination of fossils collected by Mr. Gabb in San Domingo :-

Caryophyllia.

Paracyathus.

Trochocyathus.

Flabellum.

Madracis.
Ensmilia.

Trochosmilia.

Parasmilia.

Dichocenia.

Euphyllia.
Lithophyllia.

Antilliat.

Manicina.

Colpophyllia.

Stephanocænia. 


$\begin{array}{lll}\text { Astroeenia. } & \text { Orbieella. } & \text { Stylophora. } \\ \text { Caloria. } & \text { Cyphastrae. } & \text { Siderastraa. } \\ \text { Diploria. } & \text { Goniastraa. } & \text { Agaricia. } \\ \text { Máandrina. } & \text { Solenastrea. } & \text { Porites. } \\ \text { Favia. } & \text { Plesiastraa. } & \end{array}$

It will be noticed that there are less deep-sen genera common to the tertiary and living faune of the West Indies than there are common to the European tertiary and the living West Indian ones. This might be thought to be due to smaller changes of level in the latter region than in Europe. But if we assune, as we can with great probability, that the West Indian extinct genera belonging to the fumilies of Turbinolide and Parasmilida, which are quite numerous, were deep-sea corals, this reasoning fails, and we are led to the conclusion that there has really been a great ehange in the West Indian deep-sea fama; or, in other words, that the tertiary deep-sea fama of Europe hats, as it were, migrated westward and maintained itself, whilst the greater part of the cotemporaneous forms of the West Indian deep sea have become extinct.

Cambridge, February, 1871. 


\section{EXPLANATION OF THE PLATES.}

\section{PLA'TE YI.}

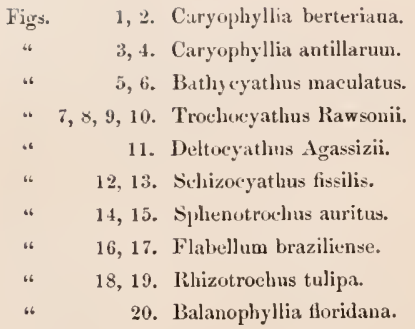

\section{PLATE VII.}

Fig. 1. Canosmilia arbuscula.

" 2, 3. Lophosmilia rotundifolia.

“ 4, 5, 6. Antillia explanata.

" 7. Cladocora patriarca.
Figs. 8, 9. Stylaster punctatus.

"10. Distichopora harbadensis.

"11. Distichopora cervina.

\section{PLATE VIII.}

Fig. 1. Axohelia dumetosa.

" 2. Axohelia Silurammi.

" 3. Axohelia myriaster.

4. Axohelia mirabilis.

\section{PIATE IX.}

Figs. 1, 2. Mycedium Cailleti.

" 3, 4. Guynia annulata.

" 5, 6, 7. Huneania barbadensis.

4. 8. Antipathes columnaris.

" 9. Antipathes humilis.

"10. Antipathes abietina. 

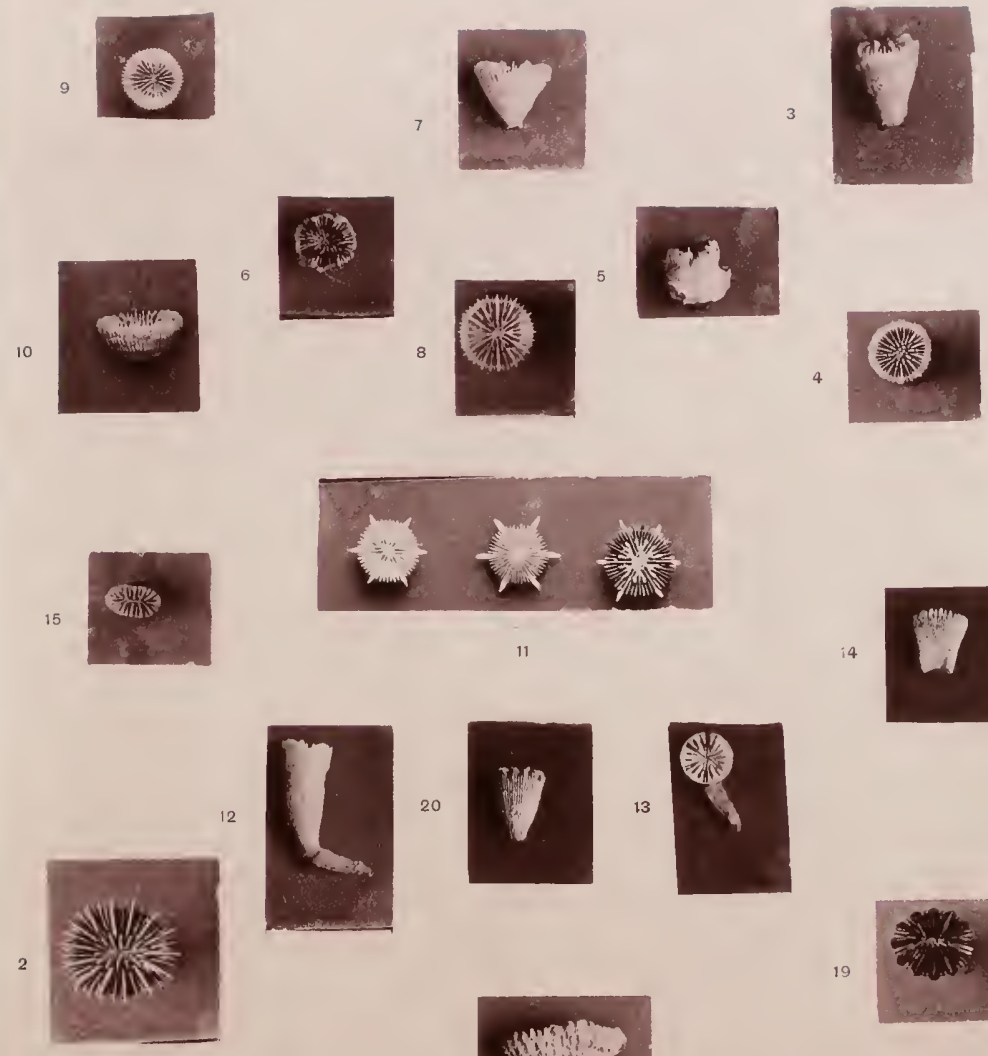

13
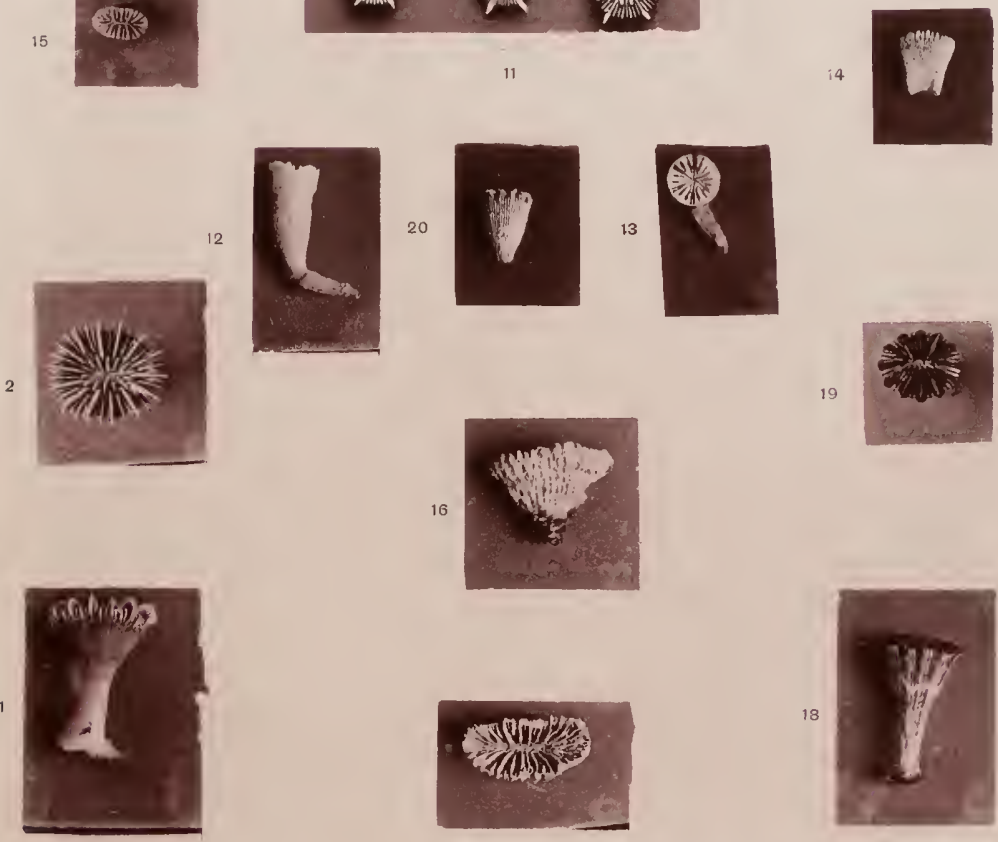

19
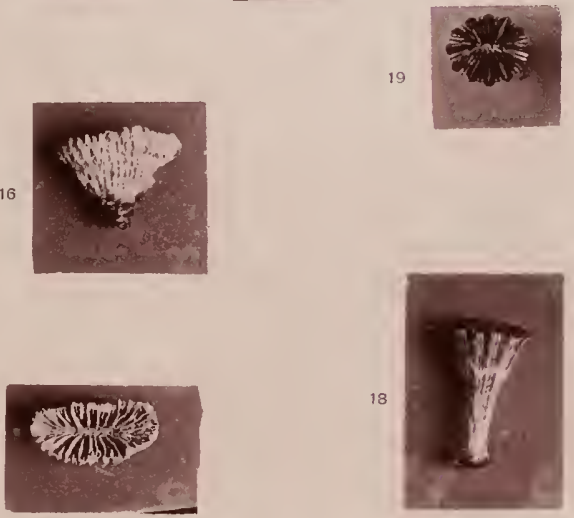

17 

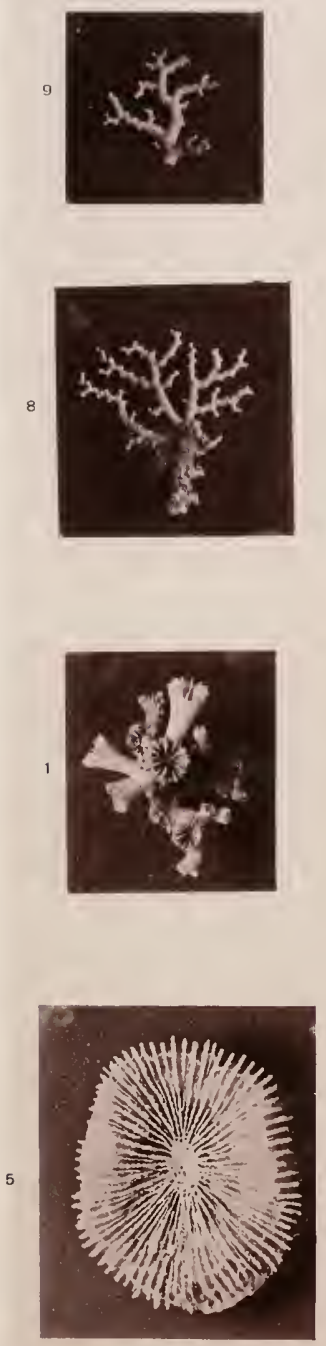
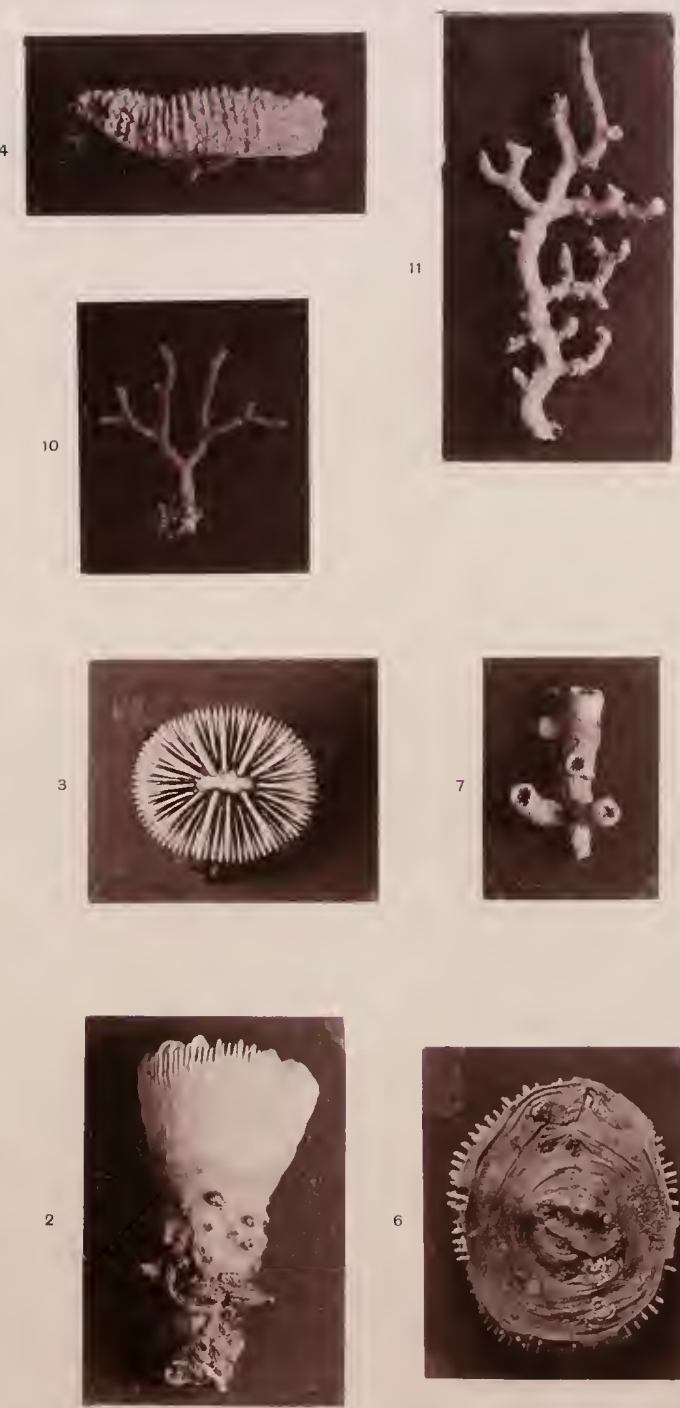


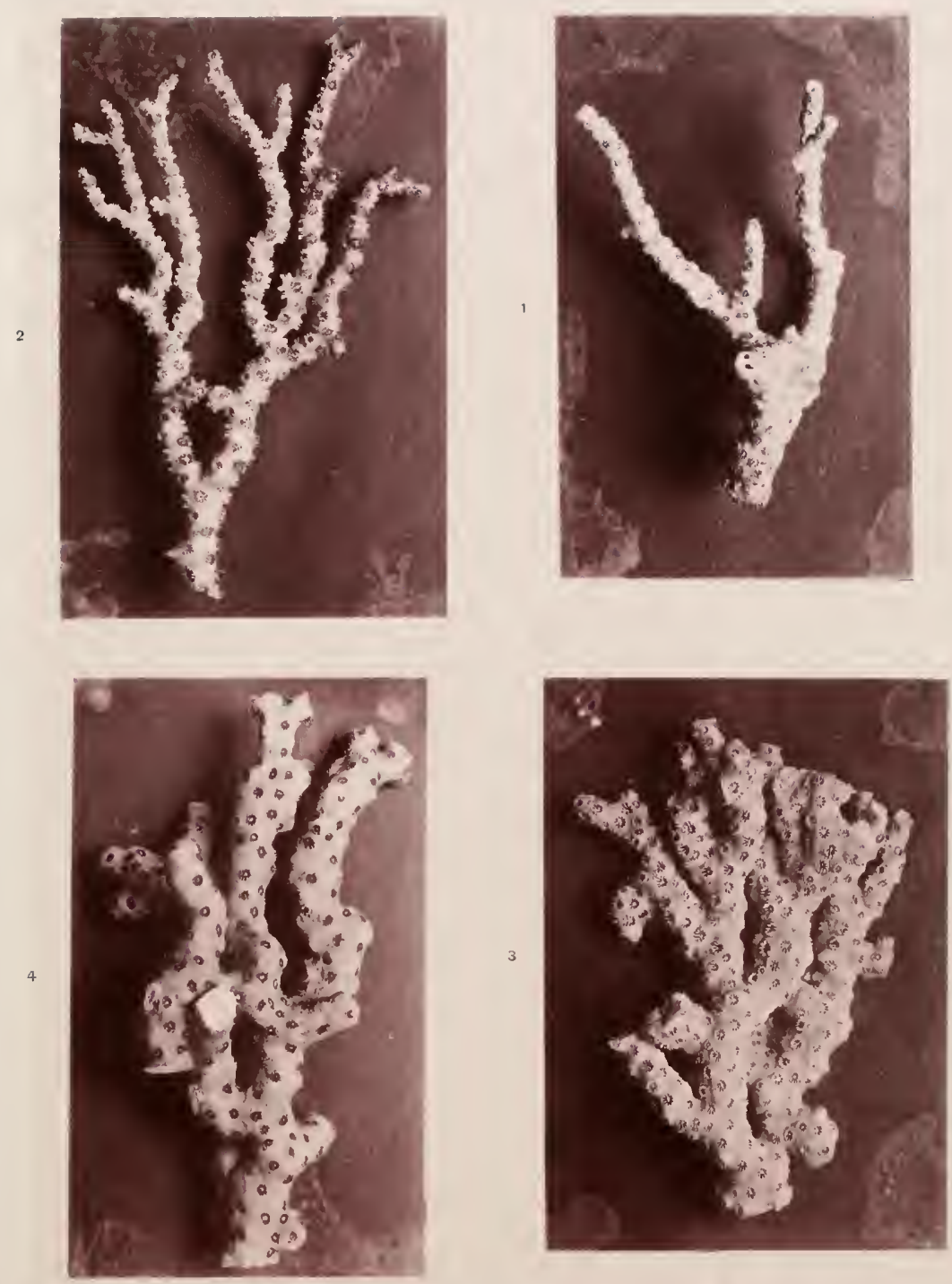


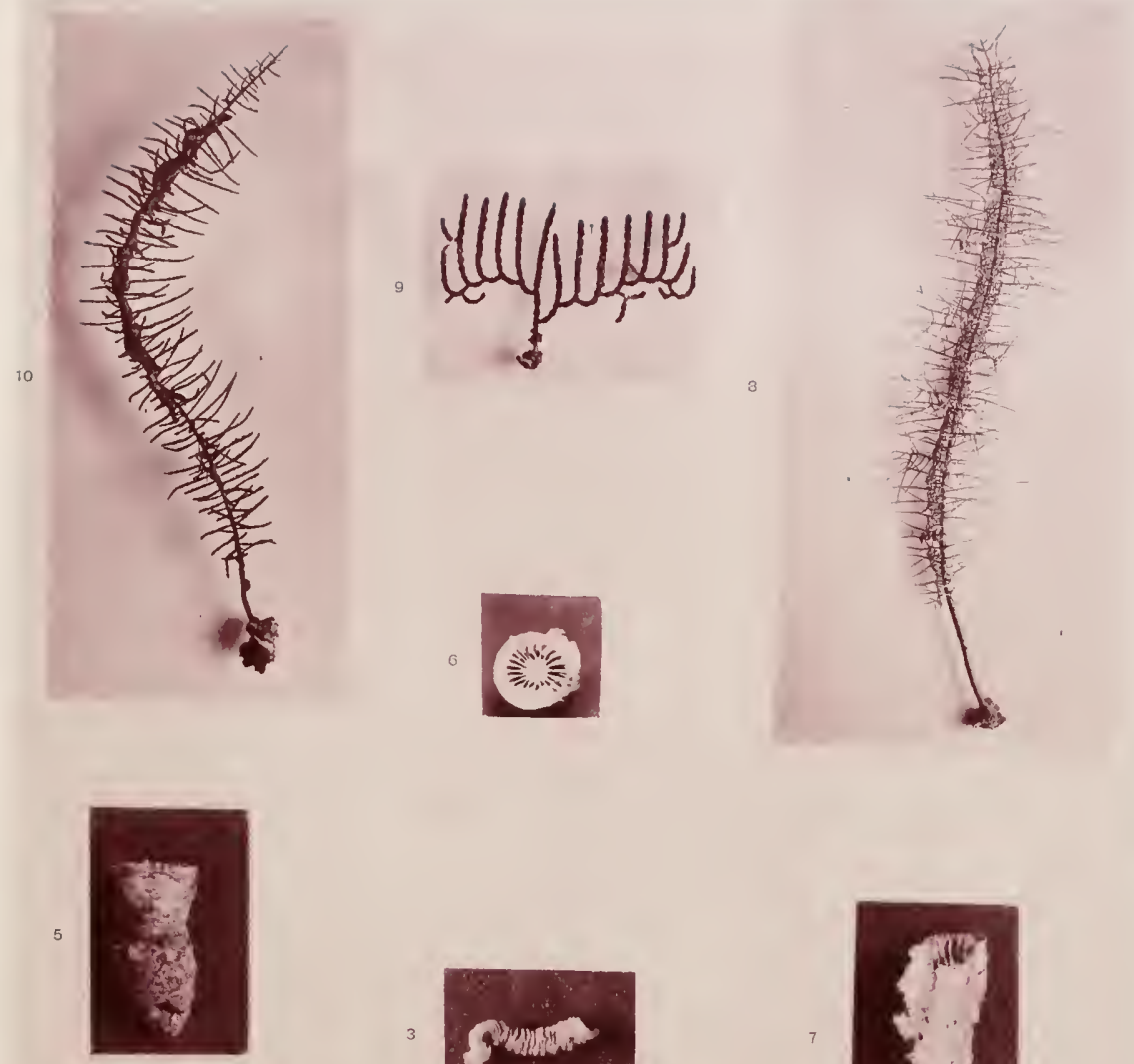

3
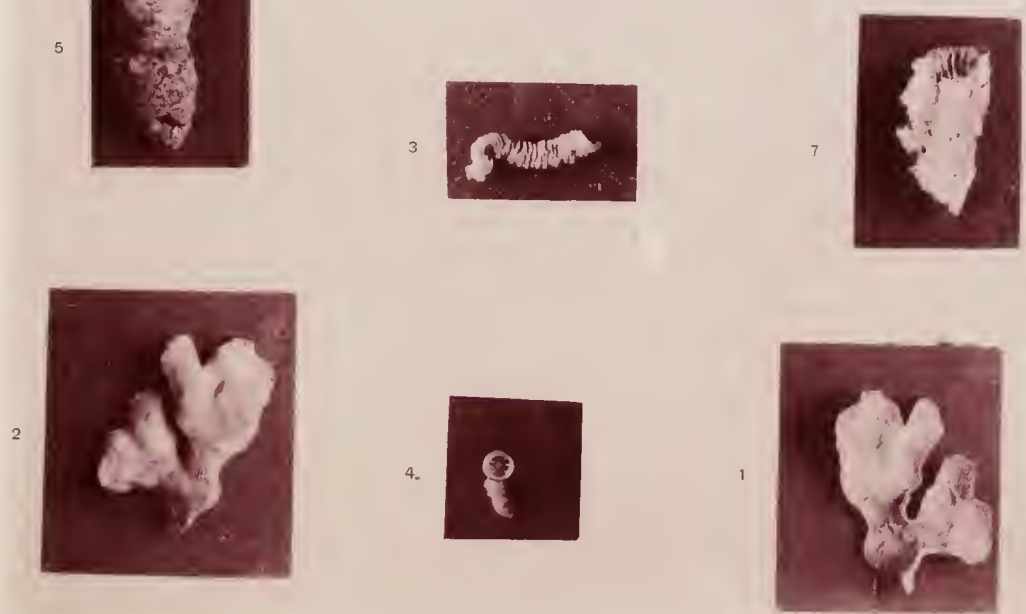

A SONREL, Prootog. 

Tasster tíx.

I\% X
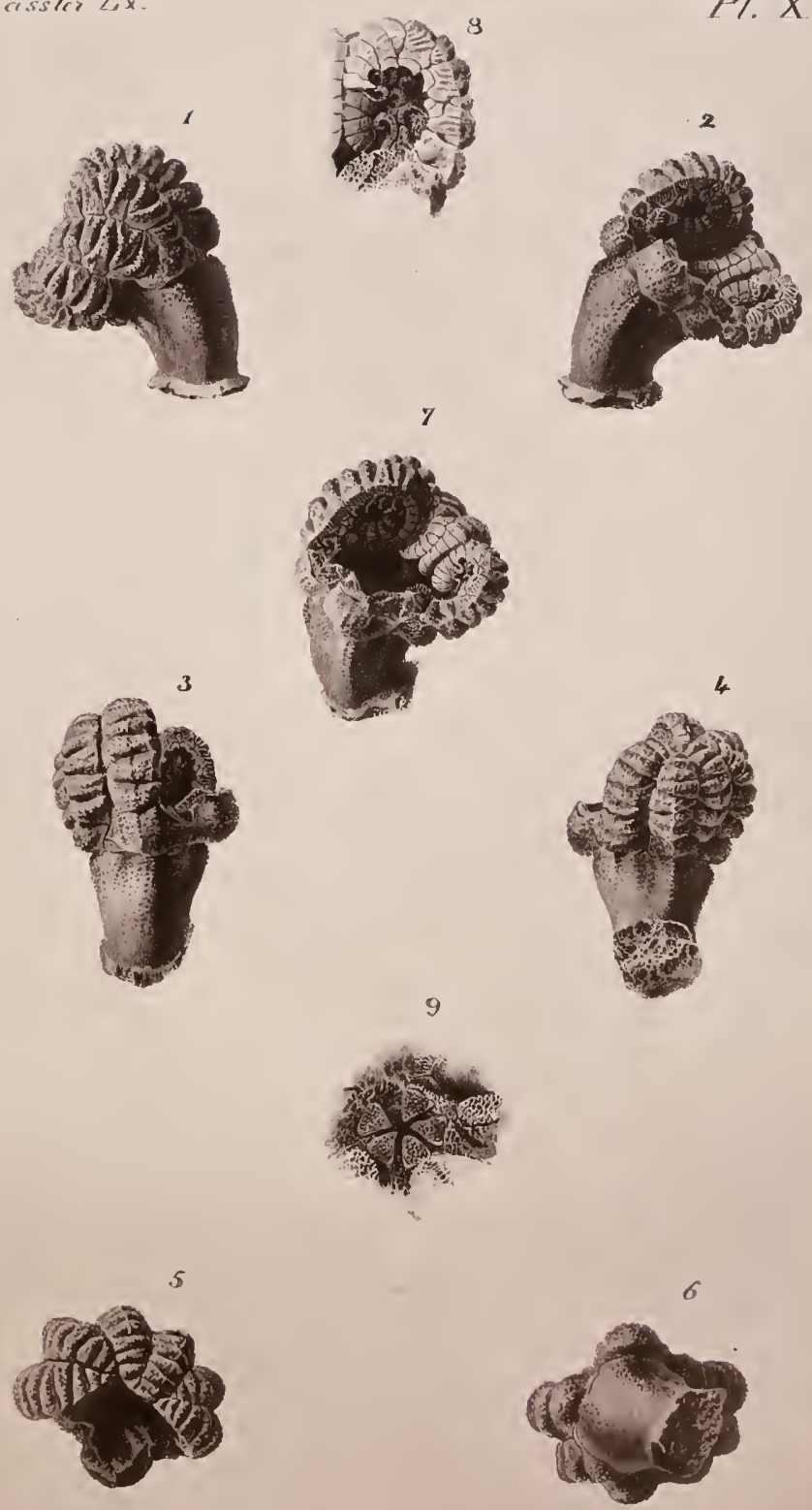

E: Knempoictyly Hel 



\section{ILLUSTRATED CATALOGUE}

OF THE

\section{MUSEUII OF COMPARATIVE ZOÖLOGY, \\ AT HARVARD COLLEGE.}

No. VIII.

70ÖLOGICAL RESULTS OF THE HASSLER EXPEDITION,

PUBLISHED BY PERMISSIUN OF THE NLPERINTENDENT OF TIE U. S. COAST SURVEY.

\section{II.}

\section{OPIIURIDA A ND ASTROPIYTIDE,}

INCLUDING THOSE DREDGED BY THE LATE DR. WLLLIANI STIMPSOY.

BY TIIEODORE LIIAN.

WITH FIVE PLATES AND FIVE FIGURES PRINTED IN THE TEXT.

UNIVERSITY PRESS, CAMBRIDGE, WELCH, BIGELOW, \& CO.

1875. 



\title{
LIST OF TIIE OPIIIURIDE AND ASTROPIIYTID E
}

\section{Collected by the Hassler Expedition and by Dr. William Stimpson.}

\author{
Abbreviations. - H. E., Hassler Expedition; W. S., William Stimpson.
}

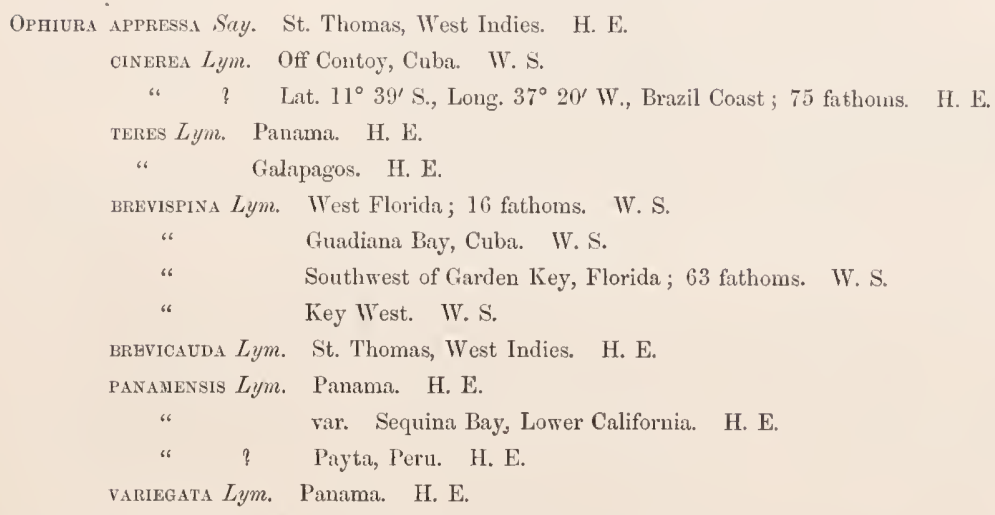

Ophopepale goesiana $L j$. Barbitoes; 100 fathoms. H. E.

Ophiolepis paucispina M. \& T. St. Thomas, West Indies. H. E.

elegans Ltk. Off Charlotte's Harbor, Florida; $13-30$ fathoms. W. S.

" St. Thomas. H. E. - Key West; 81 fathoms. W. S.

" Guadiana Bay, Cuba. W. S.

Ophiozona impressa Lym. St. Thomas, West Indies. H. E.

PACIFICA. Panama. H. E.

Nives sp. nov. Barbadoes; 100 fathoms. H. E. - Cape S. Antonio, Cuba ; $42+$

fathoms. W. S.

Ophoceramis albiba Lym. Off Rio La Plata; $19-44$ fathoms. H. E. - East Argentina ; 34 fathoms. H. E. - Rio Janeiro Harbor. H. E. - Barbadoes, 100 fathoms. H. E.

URHIOCERAMIS JaNUARII Lym. Brazil? H. E.

“ Off Bahia, Brazil ; 40 faths. Cape Frio, Brazil ; 35 faths. H. E.

" Barhadoes; 100 fathoms. H. E.

“ San Mlatias Bay, East Patagonia. H. E. 
Dphioplocus Esmarki Lym. Five miles south of Santa Barbara, California ; 22 fathoms. II. E. Ophiogliphi Lyani $L j n$. Lat. $51^{\circ} 26^{\prime} \mathrm{S}$., Long. $68^{\circ} 5^{\prime} \mathrm{W}$.; 55 fathoms. H. E.

Ophoglypha acervata Lym. Barbadoes; 100 fathoms. H. E.

" Off Sand Key, Florika ; I2S fathoms. W. S. - South of Sombrero K., Florida; 11 fathoms. W. S.

“ West eoast of Florida; 42 fathoms. W. S. - Lat. $21^{\circ} 14^{\prime}$ X.; I00 fathoms. W. S.'

Lütkexi Lym. Fire miles sonth of Santa Barbara ; 22 fathoms. H. E.

Ophiomusium acuferum sp. nov. West of Florida; 42 fathoms. W. S. - Barbadoes; 100 fathoms. H. E.

testuno sp. nor. Barbadoes; 100 fathoms. H. E.

Ophiocoms eтнiops Ltk: Galapagos. H. E.-Panama. II. E.

punila Ltk. St. Thomas, West Indies. H. E.

echinata Agus. St. Thomas, West Indies. H. E.

Rirse1 Ltk." St. Thomas, West Indies. H. E.

PAPILLOSA sp. nov. Off Santa Barbara ; 22 fathoms. H. E.

Ophiophouis Cary Lym. South of Santa Barbara, California ; 22 fathoms. H. E.

Ophiacantha pentacrinus $t t k$. Off Sand Key, Florila; $i t$ fathoms. W. S.

stellata sp. nov. Barbadoes; 100 fathoms.

Hinsuta sp. nov. Sombrero Key, Florida; 240 fathoms. W. S. - Barbadues; 100 fathoms. H. E.

marsupialis sp. nov. Juan Fernandez; 240 fathoms. H. E.

Ophiomitra valida Lym. Barbadues; 100 faths. H. E. - Sand Key, Fla.; 128 faths. IV. S. CERvicornis sp. nov. Off Contoy, Cuba? W. S.

Ophomyces frutectosus Lym. West Florida; 100 faths. W.S. - Batrbaloes; 100 faths. H. E.

Ophiactis Mülleri Ltk. St. Thomas. H. E. - Key West. W. S. [var. quinqueradia]. Off the Abrolhos; 30 fathoms. H. E. - Southwest of Garden Key; 8- 15 fathoms. W. S.

yosilus $L y m$. Off Sombrero Key, Florida; 240 fathoms. W. S.

Mageldaxica $L j$. S Sandy Point, Pat. H. E. - Gulf of Sin Matias, Santa Magdalena,

H. E. - Puerto Bueno, Eden Harbor, Pat. H. E. - Conner Cove, Pat.; 14 fathoms. H. E, - Southeast coast of South America near Bahia Blanca; 14 fathoms. H. E.

Kroveri Ltk. Pisco Bay, Peru. H. E.- Talcahuano Bay, Chili. H. E.

Ophionereis reticulata Ltk. liey West. W. S. - Rio Janeiro Harbor. H. E. - Off Cape Frio, Brazil. H. E. - St. Thomas. H. E.

annulata Ltk; Panama; 35 fathoms. H. E. - Panama. H. E. - Jaures 1sland,

Galapagos. H. E.

Amphidra grandisquama Lym. Off Sombrero; 240 fathoms. W. S. - Southwest of Sand Key ; $13+$ fathoms. W. S.

Stimpsonil Ltk: Off Cape Frio, Brazil ; 35 fathoms. H. E.

texera Ltk. Off Cape Frio, Brazil ; 35 fathoms. H. E.

Duplicata sp. nov. Barbadoes; 100 fathoms. Brazil. H. E. 
Amphivra barbare sp. nov. Sunta Barbara, California; 22 fathoms. II. E.

flexuosa? Lin. Barbadoes; 100 fathoms. H. E. - Key Biseayne, Fla. Dr. Palmer. CHiLExsis? Let: Chili. H. E.

Eugenizi $L j$. East Putagonia. Lat. $51^{\circ} 26^{\prime} \mathrm{S}$, Long. $68^{\circ} 5^{\prime} \mathrm{W}$; 55 fathoms. H. E.

“ var.? Northeast Patagonia. Lat. $40^{\circ} 22^{\prime} \mathrm{S}$., Long. $60^{\circ} 35^{\prime} \mathrm{W}$.; 30 fathoms. H. E.

REPExs sp. nov. West eoast of Florida; 14 fathoms. IV. S.

Axomala sp. nov. Juan Fernandez; 220 fathoms. H. E.

Magellanics ? $\mathrm{Ljn}$. Northeast of l'atagonia ; Lat. $41^{\circ} 40^{\prime} \mathrm{S}$., Long. $63^{\circ} 13^{\prime} \mathrm{W}$.; 30 fathoms. H. E.

squausa Surs. Talcahnano Bay, Chili. H. E.

Ophocnida scabriuscula Llym. var. Sumbrero Key, Fla. W. S.

olivacea Lym. Off Florida Reefs; $100-120$ fathoms. Wr. S. - Sombrero Key;

74 fiths. W. S.-Lat. $35^{\circ}$ S., Long. $50^{\circ} 15^{\prime}$ W.; 70 faths. H. E.

filogranea sp. nov. Cedar Kiey, Florida. Dr. Palmer.

Ophostigma isacanthum Lth. Off Cape Frio, Brazil ; 35 fathoms. H. E. -- Inside Sombrero.

Key. W. S. - West Florida ; $13-20$ fathoms. Sonthwest of

Garden Key; 63 fathons. W. S. - Key West, Flurida. W. S.

Ophiopsila Rinsei Ltk: Key West, Florida. W. S.

Opinoplax Lungmani gen. et sp. 110v. liarbadoes; 100 fathoms. H. E.

Ophothrix magifica Lym. Payta, Peru. H. E.

" var. (ralapagos. H. E.

Suensonil Ltk: Barbadoes; 100 fathoms.

spiculata LuChate. Magdalena Bay, Cal. H. E. - Panama. H. E.

violaces M. \& T. Aspinwall; Rio Janeiro Harbor. H. E. - Near Bahia, Brazil;

Lat. $11^{\circ} 49^{\prime} \mathrm{S}$, Long. $37^{\circ} 27^{\prime}$ W. H. E. - Off Cape Frio, Brazil; 35 fathoms. Barbudoes; 100 faths. H. E. - St.

Thomas. H. E. - West coast of Florida? Guadima Bay,

Cuba. W. S. - Key West. W. S. - Off Charlotte's Harbor,

Florida; 11-50 fathoms. W. S. - Sombrero; 54 fathoms.

W. S. - Mugeres Island, Yucatan. W. S.

Orstedil Ltk. Key West. W. S. - St. Thomas. H. E.

Ophiopuragues Wurdemani Lym. var.? Off Sombrero Key, Florida; 47 fathoms. W. S.

Ophioscolex Stmpsosi sp. nov. Sombrero Key, llorida; 240 fathoms. W. S.

Ophiomya flaccida Ltk. West Florida; 50 fathoms. Wr. S. - Near Bahia, Brazil. H. E.

Astrophyton Krebsil Lth. Barbadoes. H. E. Gov. Ratrson.

Astrophiton Pourtalesi sp. nov. Off East Patagonia, Lat. $44^{\circ} 52^{\prime}$ S., Long. $64^{\circ} 10^{\prime} \mathrm{W}$, Lat. $51^{\circ} 26^{\prime}$ S., Long. $68^{\circ} 5^{\prime} \mathrm{W}$.; 55 fathoms. H. E. spinosum sp. nov. Panama. Mr. Landsberg.

Astrotoma Agassizir gen. et sp. nov. Straits of Mrgellan, Pacifio side; 135 fathoms. H. E.

Astroschema tenue sp. nov. 100 fathoms. Barbadoes. H. E.

oligactes Ltk: 100 fathoms Barbadoes. H. E. 
Astrocxidis isidis Lym. Barbadoes? H. E.

Astroporpa anvelata $L t k$. Barbadoes; 100 futhoms. H. E.

Astrogonphus vallates Lym. Sombrero Key, Florida; 128 fathoms. W. S. - Off Sand Key;

270 fathoms. W. S.

Ophiocreas udubricus Lym. Off Sand Key; $75-128$ fathoms. W. S.

The above list of seventy-six species, whereof nineteen are new, may be called a remarkable one. It embraces depths from the littoral zone to 424 fathoms, the greatest number of interesting things having been brought $1 p$ in 100 fathoms, off the Barbadoes. Thence came the simplearmed Astrophytons, thus far chiefly characteristic of the West Indies, though exploration may find others elsewhere, since already we have an Astroschema from the Great Ocean, Astrotom from the Straits of Magellan, and Astronyx from North Europe. The West-Indian fauna is extended to Patagonia by Ophioceramis Jamuarii. That of extreme Sonth America shows a resemblance to the northern, since Ophiactis magellanica, Ol hioglypha Lymani, and Astropleyton Pourtalesii are comparable to $O$. Brtlii, O. citiuta, and A. Linckii of the opposite zone. Other species, however, such as Astrotoma Agassizii and the Amphinere do not hear out this resemblance. From Chili comes an Amphiura not to be distinguished from A. squamuta of the northern seas. The genus $O$ phioscolex, thus far known from polar waters only, finds a representative in the West Indies. In my generic distinctions, especially those which centre about $O_{1}$ hiucenthu, I desire not to be held strictly accountable: the classification nceds a revision which we have not yet materials to warrant. 


\title{
DESCRIPTIONS OF NEW GENERA AND SPECIES.
}

\section{Ophiomusium acuferum sp. nov.}

\author{
Plate 1. f. $1-5$.
}

Special Marks. - A supplementary arm-spine on the upper surface of the side arm-plate. A few large grains on the back of the disk. The margin of the interbrachial space formed by a swelled plate having a deep indentation.

Description of an Indiridual. - Diameter of disk, $7^{\mathrm{mm}}$. Width of arm without spines, $2^{\text {mm. }}$. Length of arm about $15^{\mathrm{mm}}$. Mouth-papillæ four on each side, and one diamond-shaped, at the apex of the jaw ; all forming a continuous line, as is usual in the genus. The mouth-frames and jaws seen from the side (Fig. 4) have a humpy, shapeless look, and bear at their apex a sinall jawplate which carries two or three small spiniform teeth. Mlouth-shields large, five-sided, with a long acute angle within, whereof a part is bounded by the inmer ends of the genital openings ; length to breadth, $1.4: 1.3$. Side mouthshields long triangular, with variously curved sides; they scarcely meet within, and are partly separated from the inonth-shield by the inner ends of the genital openings. There are only two under arm-plates of conspicuous size: these are the second and third, which are pentagonal, with an angle inward, and lateral and inmer lateral sides re-enteringly curved; length to breadth (3d plate), $.8: .8$. Beyond, the under arm-plates are ninute triangular scales just at the angle of junction of the side arm-plates. These last are thick, swollen, meeting broadly above and below, and composing the alnost entire covering of the arm on the part beyond the disk. Near the tip of the arm (Fig. 3) there is neither upper nor under plate, and the joints are elongated and larger at their outer end. Upper arm-plates minute, triangular, with an angle inward; length to breadth, on joints near the disk, .4 : .7. Disk covered with plates, of which some are unusually thick and swollen; the central space inside the radial shields is set with flat angular plates, 
many of them rudely hexagonal, and each bearing usually from one to four large grains. Almost the entire margin of each interbrachial space is occupied by a thick swollen plate having a depression in its border; it descends to the lower surface, where it joins the mouth-shield; the covering of the lower interbrachial space is completed by two massive genital scales which run from the mouth-shield to join the onter corners of the radial shields, which are so large and swollen as to resemble the halves of an egg. They touch at their middle point, but diverge both outward and inward. Within they are separated by a large disk-plate, and withont by a triangular button which rests on the top of the arm; length to breadth, 1.8:1.4. Arm-spines two, cylindrical, tapering, about $.4^{\mathrm{mm}}$ long. Besides these there is on the upper surfice of the side arm-plate a supplementary spine somewhat longer than the others. Tentacle-scales are only on the second and third plates; they are circular, and situated at the inner corners. The tentacles are slender, pointed, and smooth (Fig. $\tilde{z}$ ).

Color, in alcohol, white.

Hassler Expedition; Barbadoes, 100 fathoms. Dr. William Stimpson; West Florida, 42 fathoms.

This species agrees with $O$. vutidum Ljn. as to its under arm-plates, but differs in having supplementary arm-spines, only two regular arm-spines, and grains on the disk.

Opliomusimm represents the maximum development of external plates, and the minimum of internal skeleton. The figure shows how poorly formed are the mouth-frames, jaws, and jaw-plate; and the arm-bones are still more insignificant. Instead of the strong disks found in genera witl delicate skins, such as Ophiomyxa and Ophiura, there are only weak bones, which, in profile, are pinched in the middle like an hour-glass.

\section{Ophiomusium testudo sp. nov.}

$$
\text { Pl. I. } f .6-8 \text {. }
$$

Special Mrarks. - Two or three minute arm-spines. No under arm-plates beyoud the third.

Description of an Individual. - Diameter of disk, $5.5^{\mathrm{mm}}$. Wilth of arm, without spines, $1.8^{\mathrm{mm}}$, close to disk. Length of arm, 12.5 ${ }^{\mathrm{mm}}$. Mouth-papillie four on each side, and one diamond-shaped, at the apex of the jaws, all forming a closely soldered line. Mouth-shields longer than broad, pentangular, with a 
short angle within, at the corners of which begin the genital openings; length to breadth, 1.1:.7. Side mouth-shields large, long triangular, wide without, and with straight sides, touching by their narrow ends within. There are only two under aru-plates besides the first at the corner of the mouth-slit. They are pentagonal, with an angle inward, and the lateral sides re-enteringly curved; length to breadth, .7: .7. Beyond the third there are no under arm-plates at all. Sirle arm-plates thick, and composing the entire covering of the arm beyond the disk, excepting the small upper arm-plate. Upper arm-plates very small, diamond shape, with an angle without and within; length to breadth, .4:.5. Disk rather high and angular, covered by closely soldered swollen plates, having decided grooves between them; the upper margin is occupied by two large rounded plates, one above the other, touching the radial shield on either side; the central space within the radial shields is covered by a large pentagonal primary plate surrounded by two irregular concentric rows of smaller and rounder plates. The interbrachial space below is covered by five pieces besides the mouth-shield, to wit, three lumpy plates, arranged in a triangle just outside the mouth-shield, and two wide solid genital scales, which start at the inner corner of the genital openings and touch the radial shields with their outer ends. Radial shields roughly triangular, not much swollen, touching without, separated within by a small wedge-scale and a large round plate; length to breadth, 1.3 : 1.2. Arm-spines very small, rounded, blunt; two or three in number, and set in a notch low down on the outer edge of the side arm-plate (Fig. S). Tentaclescales only on the second and third plates; they are circular, and situated at the inner corners.

Color, in alcohol, white, clouded with pale brown.

Hassler Expedition, one specimen; Barbadoes, 100 fathoms.

It differs from O. validum $\mathrm{Ljn}$. in wanting rudimentary under arm-plates, and from $O$. Lymani $W$. Thoms. in fewer and shorter arm-spines; from both these species it differs in the smaller radial shields, higher disk, and more swollen disk-plates, which besides are differently arl'anged.

\section{Ophiozona nivea sp. nov.}

Outline figures, 85,86 .

Speeial Mtarks. - Primary plates forming a conspicuous rosette in centre of disk. A radiating line of plates in each upper interbrachial space. Lower arm-plates hexagonal. 
Description of an Indiritual. - Diameter of disk, $9^{\mathrm{mm}}$. Width of arm without spines, $3^{\mathrm{mm}}$. Length of arm, $32^{\mathrm{mm}}$. Nouth-papilla thirteen to each

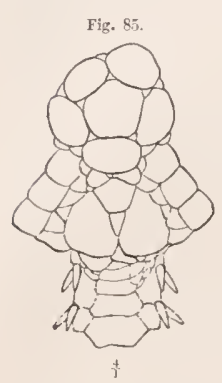
angle, all similar, blunt, rounded, spiniform; the outer ones largest, and all standing on the jaws, except the onter one on either side, which touches the side mouth-shield. Mouthshields longer than broad, oval with a peak inward; length to breadth, 1.5: 1. Side mouth-shields meeting within, strongly bent outwards. Under arm-plates hexagonal, with an angle towards each side; lateral sides re-enteringly curved; length to breadth, $1: 1.2$. Sile arm-plates not prominent, and not meeting either above or below. Upper arm-plates rudely hexagonal, wider than long; length to

breadth, $1: 2$. The first two or three are small, and more or less distorted by the encroachment of irregular supplementary scales or plates. Disk

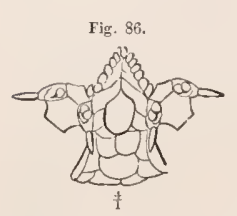
covered with large plates, whereof a portion only are surrounded by smaller ones. On the back and in the centre a conspicuous rosette of the six large primary plates, partly separated by some minute ones; from these radiate single lines of plates in each interbrachial space, separated by smaller ones from the radial shields. The interbrachial spaces below are covered by large imbricated plates and wide genital scales. Radial shields wide, triangular, strongly diverging, touching by their outer ends; separated by a wedge of a large and a small scale; length to breadth, 2.1 : 1.8. Arm-spines four, short, rounded, tapering, of about equal lengths, $1.2^{\mathrm{mm}}$. Tentacle-scales rounded, standing close together on the side armplate; and outside them is a lip or little ridge.

Color, in alcohol, white.

Hassler Expedition; Barbadoes, 100 fathoms. Dr. William Stimpson; Cape San Antonio, Cuba, 424 fathoms.

\section{Ophioceramis albida.}

Amphipholis albida, Lunngman. Ophiuroidea Viventia, 314.

Pl. III. f. $29-31$.

Many specimens which agree with the descriptions and with my notes on the originals at Stockholm were bronght from moderate depths in the neighborhood of Rio La Plata. As Ljungman has suggested, the species comes under Ophiocramis. 


\section{Ophiocoma papillosa sp. nov.}

Special Narks. - Numerons (twenty or thirty) tooth-papille. One or two scale-like spines overlapping the base of each upper arm-spine.

Description of an Indiridunl. - Diameter of disk, $10^{\mathrm{mm}}$. Length of arm, $45^{\mathrm{mm}}$. Mouth-papillae small, four on each side. Tooth-papillie from twenty-two to thirty, crowded, those in centre smallest. Teeth four. Month-shields and arm-plates similar to those of 0 . Alexandri, except that the upper arm-plates are not so regular nor so wide. Disk closely, finely, and evenly granulated, with about seven grains in the length of a $\mathrm{mm}$; ; below, the granulation is less close. Arm-spines four, smooth, tapering, rather slender; lengths, 2, 2, 1.5, 1.3. Besides these, there are usually two scale-like spines overlapping each other and the base of the upper arm-spine. One large tentacle-scale. Tentacles, in alcohol, purple and set with many papillæ, while those of 0 . Alexandir are nearly or quite smooth.

Color, in alcohol, pale brown.

Hassler Expedition; Santa Barbara, California, 22 fathoms. A young one from the same locality had a disk of $4^{\mathrm{mm}}$. It had already fifteen tooth-papilla, while the large specimens of 0 . Alexandri have only nine; and there were to be seen the supplementary scale-like arm-spines.

0 . papillosa belongs with 0 . pumila, $O$. Valencice, and O. Alcxandri, in the division of Ophiocoma having flat arms, one tentacle-scale, and a light structure.

\section{Ophiacantha stellata sp. nov.}

Pl. II. f. $16-18$.

Spccial Marks. - Disk beset above with minute stumps, each with a crown of four or five thorns. A strong stricture between the joints of the arm. Upper arm-spines long and needle-like.

Deseription of an Indiridual. - Diameter of disk, 3.5 $5^{\mathrm{mm}}$. Width of arm without spines, $1.1^{\mathrm{mm}}$. Length of arm, $26^{\mathrm{mm}}$. Mouth-papillie seven, stout, spiniform, not set close together, all similar in form, but the odd one under the teeth larger; those on each side stand on the jaws. Month-shields very wide diamond-shape, with a rounded angle without, and an acute one on either side; length to breadth, .5:1. Side mouth-shields narrow, their outer side curved, meeting within. The first under arm-plate at the corner of the mouth-slit is hexagonal; the second triangular with an angle inward, bonnded without by a curve, and on the sides by re-entering curves; the third plate, 
and those beyond it, squarish, with a slight peak within and the sides re-enteringly curver. Side arm-plates very large, widely meeting above and below; their outer portion rises in a thick ridge, to earry the arm-spines, which gives a knotterl look to the arm (Fig. 18). Upper arm-plates small, triangular, with an acute angle inward; the onter margin curved; the laterals re-enteringly eurved; length to breadth, .5: $: 5$. The onter part of each plate is bent downward. Disk strongly contracted in the interbrachial spaces, giving to it a star shape. Above, elosely set with minute stumps, each bearing a crown of four or five thorns and sitting on a thin round diskseale which is not readily seen. There are about six stumps in the length of a mm. Below, the interbrachial space is naked, or has but few stumps. Radial shields only visible at their outer ends, as two narrow swellings lying in contact. Arm-spines seven, the upper very long; all of them slender, glassy, and with a few sharp thorns. The joints within the disk have four short, very jagged spines; the longest one $.6^{\mathrm{mm}}$ long. Beyond the disk the two upper spines attain a length of $1.8^{\mathrm{mm}}$. Tentacle-seales long and narrow; one to each of the tentacles, which are small and slender.

Color, in alcohol, yellowish-brown.

Hassler Experition : Barbadoes, 100 fathoms.

\section{Ophiacantha hirsuta sp. nov.}

$$
\text { Pl. II. f. } 21-23 \text {. }
$$

Special Murks. - Jaws elongated, and bearing about seven spine-like papillie on each side, besides one larger under the teeth. Disk beset above with short fine spines. Arm-spines serrated. Two large tentacle-seales. Radial shields covered except their outer ends.

Description of an Individual. - Diameter of disk, $6^{\mathrm{mm}}$. Width of arm withont spines, $1.6^{\mathrm{mm}}$. Mouth-papillwe seven or eight on each sicie and one under the teetlı; the lateral ones are spiniform, the outer ones longest, and all mounted on the jaws, which are prolonged in an acute angle; the papilla under the teeth is broader and diamond-shaped. Mouth-shields wider than long, rounled diamond-shape; length to breadth, .6:.9. Side mouth-shields narrow, slightly widened without, meeting within. Under arm-plates wider than long, bounded by a very obtuse angle within, a gentle curve without, and reentering curves on the sides; length to breadth within the disk, $.5: .7$. The first plate, at the corner of the mouth-slit, has each margin curled downwarl, 
so as to make a sort of sheath to the mouth-tentacles. Side arm-plates large, meeting above, and nearly below, and having a narrow, prominent ridge for arm-spines. Upper arm-plates small, irregular diamond-shape, with a rounderl angle without and within, and an acute angle on each side; on the median line a hump or ridge; length to breadth, $6: \overline{6}$. Disk finely scaled below, about six scales in the length of a mm., and with a short thin spine here and there; above, the scaling is not apparent. and the surface is pretty closely beset with short slender spines about $.5^{\mathrm{mm}}$ long. Radial shields covered, their outer ends only being marked by swellings. Arm-spines usually six, near disk, the second and third longest; flattened, somewhat glassy, with the edges strongly serrated, especially those of the lowest spine; lengths to that of an under arm-plate (near the disk) .7, 1.3, 1.2, 1, .8, .6 :.6. 'Tentacle-scales two, large, pointed oval, lying side by side. The tentacles, especially those of the month, are thick and smooth.

Color pale greenish, in alcohol.

Dr. William Stimpson; off Sombrero Key, Florida, 240 fathoms. Hassler Expedition; Barbadoes, 100 fathoms.

\section{Ophiacantha marsupialis sp. nor.}

Pl. I. f. $9,10$.

Speciul Wurks. - Upper arm-plates diamond shape; side arm-plates meeting above; small oval raclial shields; a few stout, short thorns on the disk.

Descrigtion of an Individual. - Diameter of disk, $3.7^{\mathrm{mm}}$. Width of arm without spines, $.9^{\mathrm{mm}}$. Length of arm, $10^{\mathrm{mm}}$. Nouth-papilla eleven to each mouthangle; thin, spiniform ; of these two on either side are much longer than the rest and stand on the broad and conspicuous jaws, just inside the monthshields; the rest are much smaller, and make a clump at the inner point of the angle, some standing on the jaws and some on the jaw-plate. Mouthshields wide diamond-shape; length to lreadth, $.4: 5$. Sile mouth-shields narrow, of about uniform width; not extending beyond the mouth-shields; meeting within. Under arm-plates narrow, longer than broad, curved without, re-enteringly curved on the sides, and presenting a rounded angle within; length to breadth within the disk, $.4: 2$. The first plate, instead of being rudimentary, differs little in size and shape from the rest. Side armplates meeting fully above and nearly below. Upper arm-plates diamond-shape, with one of the angles rounded and directed ontward; length to breadth, 
.4:4. Disk soft and smooth; naked below; but thin imbricated seales may be distinguished above. There are some scattered spines, which are pointer, a little rough, and not over.$^{\text {mm }}$ long. Radial shields not conspicuons, oval; touching at their outer points, but separated within by a scale. Arm-spines three, slender, rounded, tapering; the upper one the longest, $.6^{\mathrm{mm}}$. One tentacle-scale, which is small, spiniform, and placed on the side arm-plate. The tentacles are smooth and rather thick.

Color, in alcohol, pale greenish-gray.

Hassler Expeclition; Juan Fernandez, 240 fathoms.

The genus Ophiacentha, as now limited, contains species which vary extremely from the type O. setosa. Indeed, there is no genus in which the admitted species are so varied in their detail of structure. O. marsunialis may be placed in it as properly as some other species already there; and that, too, despite the fact that the mouth-parts and under surface in general recall, to a certain extent, Ophioscolex. The interlurachial pouches had large young ones in them, whose arms protruded through the genital openings.

\section{Ophiomitra cervicornis sp. nov.}

Il. II. f. 19,20 .

Spccial Marks. - Ten mouth-papilla, whereof three are on each side of the jaws; two at the apex, under the teeth; and two on the under surface of the jaws on each side of the median line. One tentacle-seale, having the form of a small toothed plate.

Description of an Indiridual. - Diameter of disk, $S^{\text {mun. }}$. Width of arm without spines, 2.5 $5^{\mathrm{mm}}$. Length of arm about $42^{\mathrm{mm}}$. Nouth-papille ten, all blunt, stout, spiniform, except the outer one on each side, which is rounded like a very thick scale: there are three on each side of the jaws; two at the apex, under the teeth; and two on the under surface of the jaws just inside the junction of the side mouth-shields. Moutl-shields diamond-shape; length to brealth, $1: 1.2$. Side mouth-shields short, straight, of nearly equal width. meeting within. Under arm-plates hexagonal, with the lateral angle cut off; where the tentacle comes out; length to brealth, $.8: 1$. The first plate, at the corner of the mouth-slit, has its sides bent downwards, making a sort of sheath for the mouth-tentacle. Side arm-plates stout, meeting above, but not below, having a prominent ridge for the arm-spines. Upper arm-plates triangular, with an angle inward and the outer side curved; length to 
breadth, $. S: 1$. Disk corered with somewhat thin and irregular scales, beset with a few thorny stumps. Above, the scales are somewhat elongated, two or three in the length of a mm.; below, they are smaller and rounded. The upper disk has a few coarse stumps or short thick spines, the longest about $.6^{\mathrm{mm}}$, with strong thorns; the interbrachial spaces below have fewer and shorter stumps. Radial shielels large, of an irregular four or five-sided shape, meeting at their onter ends, but separated within by a broad scale. Their outer ends bear three thorny stumps. Arm-spines eight or nine, the three uppermost longest, stout, somewhat flattened, coarsely scrrated; lengths to that of an under arm-plate $3,2.8,2.8,2.5,2,2,1.5,1.5,1$ :.8. One tentaclescale to each pore, which on the second and third plate has the shape of a toothed crescent; on the plates beyond, it is a thick scale with a toothed edge.

Color, in alcohol, pale yellowish, with brown spots in radial shields and brown bands on arms.

Dr. William Stimpson; probably from deep water on the coast of Cuba.

\section{Amphiura anomala sp. nor.}

\section{Pl. III. f. $26-28$}

Special Dlarks. - Sometimes two and sometimes three mouth-papilla on each side, of which the immermost is stoutest and is under the teeth; scaling of disk rather coarse; radial shields smatl and wholly separated.

Description of an Tulivitual. - Diameter of disk, 6.5 $5^{\mathrm{mm}}$. Wilth of arm without spines, $1.3^{\mathrm{mm}}$. Length of arm about $39^{\mathrm{mm}}$. Mouth-papilla either three or two on a side: of these one is stout, blunt, and rounded, and stands beside its fellow at the point of the mouth-frames under the teeth; the second is short, spiniform, and sits on the inner part of the side month-shield; there may or may not be a third intermediate one, also spiniform. Besides these the spiniform tentacle-scale of the first mouth-tentacle may be seen. Mouth-shields longer than broad, rounded diamond-shape; length to breadth, $.8: .7$. Side month-shields stout, triangular, with re-entering sides; not quite meeting within. Under arm-plates longer than broar, rectangular, with lateral sides slightly re-entering; length to breadth, .5:.4. Side arm-plates wide, but not prominent, nearly meeting alsove. Upper arm-plates not covering the surface of the arm, rounded, with a peak inward. Disk rather thick, and rising well off the arms; the scaling is coarse, thickened, and rather irregular, with- 
ont conspicuous primary plates; usually about four scales in the length of a mm., and even fewer on the under surface. Radial shields small, irregular oval, slightly diverging, separated by a wedge of four scales in a line and one or two smaller ones on the sides; length to breadth, $1: 5$. Arm-spines, near disk, six, rounded, tapering, sharp, increasing in length from the npper to the under one, whose lengths to that of an under arm-plate are .7, .9:.5. Tentacle-scales two, minute, and standing at right angles. Tentacles, especially those of the mouth, thick and eross-wrinkled.

Color, in alcohol, nearly white.

In young specimens the lower disk-seales are feeble.

IIassler Expedition; Juan Fernandez, 220 fathoms.

I have been of the opinion that Ijungman's genus Amplipholis was not sufficiently grounded, differing from Amphimen only in having three or four month-papillie on a side, instead of two with a space between them. The present species comes in as a comnecting form; and a glance at Plate $\mathrm{V}$. will show that the variety in number, shape, and position of mouth-papille in the genus Ampliura, ineluding Ampliphlolis, is considerable.

\section{Amphiura squamata SARs.}

I am not able to distinguish a specimen from Chili from the $A$. squamatu of Fonth and North Europe, or of North America. Already (Bull. Mus. C. Z., III. 335) I have called attention to the possible identity of species nearly allied to this and coming from distant localities. Ijungman endeavors to distinguish these species by the number of upright scales along the margin of the disk in each interbrachial space; but I satisfied myself, by counting those of many specimens, that this number varies. Thus, thirteen specimens from Spezia, having disks from $1.2^{\mathrm{mm}}$ to $2.5^{\mathrm{mm}}$, had from five to eight interbrachial scales, and the number wis not always in proportion to the size of the specimen. Two specimens from the Adriatic, with disks of $2.2^{\mathrm{mm}}$. and $2.8^{\mathrm{mm}}$, had eight, nime, or ten scales. Two from Naples, having disks of $2.2^{\mathrm{mm}}$. and 3. $\mathrm{S}^{\mathrm{mm}}$, had eight, nine, eleven, or twelve scales. This Chilian specimen, with a disk of $2.5^{\mathrm{mm}}$, had nine interbrachial scales.

Hassler Expedition ; Taleahuano Bay. 


\section{Amphiura Barbaræ sp. nov.}

$$
\text { Pl. III. f. } 32-34 \text {. }
$$

Special Mfarks. - Three sharp arm-spines. Under arm-plates with a notch without. Side mouth-shields narrow and bent and nearly meeting on the arm.

Deseription of an Individual. - Diameter of disk, $4^{\mathrm{mm}}$. Width of arm without spines, . $S^{\mathrm{mm}}$. Length of arm, $26^{\mathrm{mm}}$. Mouth-papilles six to each mouthangle, of which the two innermost run npward towards the teeth, under which they stand; the two on each side are stout, flat, with rounded edges; the outermost one stands partly on the prominent mouth-frame and partly on the side mouth-shield. Mouth-shields small, rounded diamond-shape; length to breadth, .4 :.3. Side mouth-shields narrow and much bent; meeting within, and nearly reaching the median line of the arms without. Under arm-plates squarish, with rounded corners; an obtuse angle within, and a re-entering curve without; length to breadth, .3 : .3. Side arm-plates rather weak; nearly meeting below, but widely separated above. Upper armplates much wider than long, pointed oval; length to breadth, .3: .7. Disk beset with fine thin delicate scales, which are much smaller on the interbrachial spaces below. Only the central primary plate is conspicuous by its larger size. Above there are six or seven scales in the length of a mm.; below, about sixteen. Radial shields large, pointed pear-seed shape, closely joined, or partly separated by a very narrow lime of scales; length to breadth, 1 :.4. Arm-spines three, sharp, rather slender, rounded, tapering; lowest one longest; lengths to that of lower arm-plate .4, .4, .6 :.3. Tentacle-scales two, small, wider than long; set at right angles, one on the under, the other on the side arm-plate. Tentacles large and thick.

Color, pale straw, in alcohol.

Hassler Expedition; Santa Barbara, California, 22 fathoms.

$\mathrm{t}$ bears some resemblance to the descriptions of $A$. Chilensis, but the radial shields are joined, and the three arm-spines are sharp and rather long.

\section{Amphiura flexuosa? Lus.}

Ljungman. Ophiuroidea Viventia, p. 319. Brazil.

$$
\text { Pl. III. f. } 35-87 ; \text { Pl. V. f. } 68 \text {. }
$$

This corresponds to Ljungman's description and to my notes on his origi- 
nals at Stockholm, except, 1st, the outer month-papilla can scarcely be called "spiniform"; $2 d$, the peculiar microscopic beak at the end of the third and fourth arm-spines is not mentioned by him, but might easily have escaped notice.

Hassler Expedition; one small specimen, Barbadoes, 100 fathoms. Also several larger specimens (disk, $6.5^{\mathrm{mm} .}$; arm, $45^{\mathrm{mm}}$ ), by Dr. Palmer, from Bay of Biseayne, Florida. Its general appearance is that of Ophiopsila Riisei.

\section{Amphiura repens sp. nov.}

$$
\text { Pl. III. f. } 38-40 \text {. }
$$

Spreial Marlis. - Disk naked below, finely sealed above, and without conspicuous primary plates. Three blunt arm-spines. One tentacle-scale.

Deseription of an Indiridual. - Dianeter of disk, $4.5^{\mathrm{mm}}$. Wilth of arm, without spines, $.7^{\mathrm{mm}}$. Arms long. Mouth-papilla small, rounded, flat, scale-like; three on each side of the narrow, prominent mouth-frames; the innermost one touching the inner part of the side mouth-shield. Mouth-shields rounded heart-shape, having a slight peak without; length to breadth, .3: .3. Side mouth-shields triangular, with re-entering sides; they do not meet within. Under arm-plates pentagonal, with somewhat rounded corners and an angle inward; length to breadth, .3 : .3. Side arm-plates weak, narrow, not prominent; nearly or quite meeting above and below. Upper arm-plates wider than long, with a strong curve within, and a gentle one without; length to breadth, .3:.6. Disk flat and delicate, covered above with a fine, thin scaling; about fourteen seales in the length of a mm., among which the primary plates are not conspicuous; below, the interbrachial space, except next the margin, is naked. Radial shields long and narrow, joined for their entire length, except their sharp inmer points, which are separated by a single scale; length to breadth .8 :.2. At their onter ends are two little radial seales, making a small notch in the margin of the disk. Arm-spines three, short, romded, blunt, nearly of equal lengths, the upper one stoutest; about as long as an under arm-plate. Tentacle-seale one, sitting on the side arm-plate.

Color yellowish in alcohol, with a faint stripe along the upper side of the arm.

Dr. William Stimpson; west coast of Florida ; 14 fathoms.

The back of the disk and arms is like A. levis, which is from the Philip- 
pines, and which has four mouth-papillæ on a side and two tentacle-scales. It also resembles A. pulchella, but differs from it by being naked below and having no prominent primary plates.

\section{Amphiura magellanica? LJN.}

Luungmax. Ophimroidea Viventia, 320.

The specimens agree well with the description, except that, 1st, the upper arm-plates are rather rounderl fan-shape than "oval"; and, $2 d$, the armspines are but feebly "thorny." The originals, at Stockholm, are in poor preservation; they stand near $A$. capensis, as do also these specimens, which, however, differ from it in having longer and more slender arm-spines. The largest had a disk $7^{\mathrm{mm}}$. in diameter, and arms four or five times as long; there were seven slender tapering arm-spines, increasing in length from above downward. Small radial-shields wholly separated by a row of scales. One tentacle-scale. One mouth-papilla on either side, besides the thick pair just under the teeth. The species is viviparous.

Hassler Expedition ; Lat. $41^{\circ} 40^{\prime}$ S., Long. $63^{\circ} 13^{\prime}$ W., N. E. Patagonia, 30 fathoms.

Amphiura duplicata sp. nov.

\section{Pl. $Y . f . r s$. Outline $8 \%$.}

Speciul Marlis. - First (rudimentary) under arm-plate transversely divided in two. Radial shields separated by a wedge of scales and only touching at their outer ends.

Description of an Indiridual. - Diameter of disk, $4^{\mathrm{mm}}$. Width of arm without spines, $1.1^{\mathrm{mm}}$. Length of arm, $20^{\mathrm{mm}}$. Mouth-papilla, seven ; three on each side, which are stout, blunt, spiniform, and all on the mouth-frames, and one under and similar in shape to the teeth. Mouth-shields short, heart-shape, with an angle inward; length to breadth, $.8: .8$. Side mouth-shields long, narrow, slightly curved, wider without than within, where they meet. Under arm-plates; the first is transversely divided, the inner half reaching into the

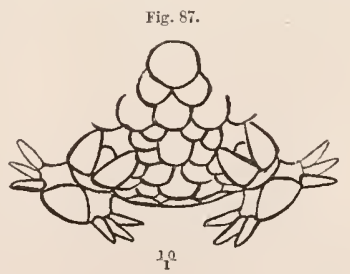
mouth-slit, while the outer joins the side mouth-shields on each side. Second plate hatchet-shaped, with an angle within, strongly re-entering curves on 
either side, and a curve without, where it is widest; length to breadth, $.8: .9$. Side arm-plates robust, and nearly or quite meeting above and below. Upper arm-plates broader than long, bounded by a strong eurve within, and by a gentle one without; length to breadth, .5 :.7. Disk covered with large, but not swollen scales, whereof the central primary one is conspicuous, having a diameter of $.6^{\mathrm{mm}}$. In a line between it and the inner ends of the radial shields there are only three seales. Radial shields pearseed shape, diverging inward and touching only at their outer extremities; separated by a wedge of two or three seales; length to breadth, $.7: 3$. Armspines, near disk, four; stout, rounded, tapering, blunt, of nearly equal length, which to that of an under arm-plate is $.5: .7$. Tentacle-seales two, small, rounded, placed at right angles, one on the under, the other on the side arm-plate.

Color, in aleohol, nearly white.

Hassler Expedition; Barbadoes, 100 fathoms. Brazil ?

\section{Amphiura chilensis? Lтк.}

Ophiolepis chilensis, MüLl. and Trosci. Wieg. Archiv. IX. 120.

$$
\text { Pl. V. f. } \pi \text {. }
$$

A speeimen from Taleahuano Bay, Chili, agrees well with the description and with my notes on the original at Berlin, except that the arms of this specimen are shorter, and the tentacle-seales larger. The description of Müller and Trosehel says one tentacle-seale, but the specimen in the Berlin Museum has two.

\section{Ophiocnida filogranea sp. nov.}

\section{Outline figures 88,89 .}

Special Marks. - Close set granules along margin and on a part of interbrachial spaces of disk. Radial shields very wide and short, and joined along their whole length. Three mouth-papillie on each side, the innermost one stoutest. Arms long and slender.

Description of an Individual. - Diameter of disk, $7^{\mathrm{mm}}$. Width of arm without spines, $1.1^{\mathrm{mm}}$. Length of arm, $72^{\mathrm{mm}}$. Mouth-papillie six to each mouthangle; the innermost two are largest, run upwards to the teeth, and are rounded; the next on either side is smaller and spiniform, and the outermost is flat with a curved edge. Mouth-shields small, longer than broad, five-sided, 
with an angle inward; length to breadth, .7 :.5. Side mouth-shields very narrow, eurved, of equal wilth, and meeting within. Under arm-plates small, squarish, with rounded corners; length to brearlth, .5:.5. Sirie arm-plates narrow and feeble, meeting neither above nor below. Upper arm-plates large, wider than long, oval, overlapping; length to breadth, .5 : 1 . Disk covered above with not very regular imbricated scales; five or six in the
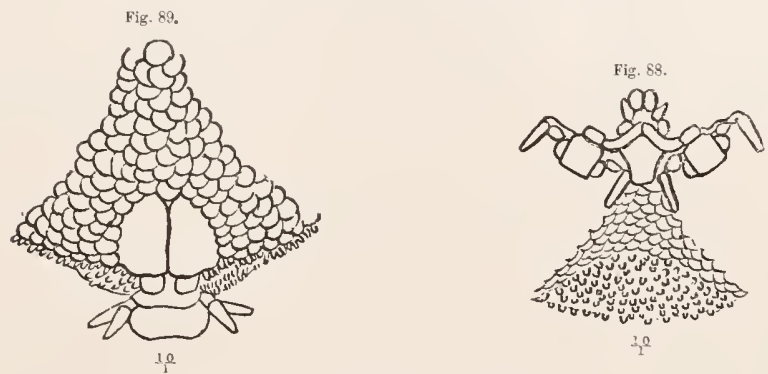

length of a mm. Among them, the primary plates may be distinguished by their larger size; the scaling below is much finer and more delicate; six or eight scales in the length of a mm. The margin of the disk and the outer portion of each interbrachial space is closely beset with granules. Radial shields wide, joined for their whole length, which to the breadth is $1.1: .7$; each has a small, squarish radial scale just over the arm. Arm-spines three, short, rounded, tapering; of about equal lengths, .6 $6^{\mathrm{mm} .}$ Tentacle-scales two, at right angles to each other.

Color, in alcohol, greenish-gray.

Dr. E. Palmer ; Cedar Keys, Florida.

This species has very much the general babit and appearance of Hemipholis cordifera. It perhaps stands nearest to Ophiocnida (Ophiophragmus Ljn.) Lnemi, but the month-papillae of this last are bead-like and nearly equal; and there are many other differences.

\section{Ophiophragmus Wurdemani VAR.?}

A specimen by Dr. Stimpson, from Sombrero Key, 47 fathoms, had the disk-scaling flatter and coarser and the mouth-papillie somewhat more beadlike than in the type. It is probably a variety. 


\section{OPHIOPLAX gen. nov.}

Teeth; no tooth-papillæ; numerous mouth-papillæ. Scaling of disk beset with gramulation. Arms long and rather stiff. Arm-spines few and smooth, arranged on the ridges of the side arm-plates. One very large tentacle-scale on the side arm-plate, and others, minute, on the under arm-plate. Two long genital openings in each interbrachial space.

The genus stands near Ophiocnida, but is distinguished by the numerous month-papilla arranged as in Ophiura, and by the singular tentacle-seales.

\section{Ophioplax Ljungmani sp. nov.}

\section{Pl. II. f. 24,25 .}

Special Marks. - Interbrachial spaces below and margin of disk minutely granulated; upper surface finely scaled, and with small, separated radialshields. One large and three minute tentacle-scales. Arus pretty long and rather stiff.

Description of an Individual. - Diameter of disk, $6^{\mathrm{mm}}$. Width of arm withont spines, $1.7^{\mathrm{mm}}$. Length of arm, $60^{\mathrm{mm}}$. Mouth-papilla five on each side, and one under and similar in form to the teeth. The papillæ are flat and crowded; the one next the outermost much wider than the others. Mouthshields small, egg-shape, with the point inward; length to breadth .8 : .7. Side mouth-shields very small and narrow; joining the side arm-plates with their outer ends; not meeting within. Under arm-plates rather wider than long, with a curve without, an obtuse angle within, and re-entering curves on the sides; length to breadth, $.7: .8$. Side arm-plates nearly meeting below, but well separated above. Upper arm-plates much wider without than within; the outer side curved; the lateral sides straight and sloping towards the median line; length to brealth, $.7: 1.4$. Disk finely scaled above, six scales in the length of a mm., where they are finest. The margin and under surface covered by a minute granulation, about sixteen grains in the length of a $\mathrm{mm}$. Radial shields small, irregularly oval, widely separated by three or four parallel lines of seales; length to breadth, 1:.4. Arm-spines three, of nearly equal lengths; slender, rounded, smooth, tapering; the longest,

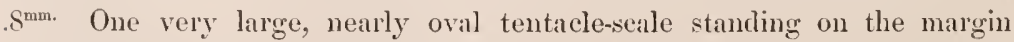
of the side alm-plite; and three minute ones arranged along the lateral side of the under arm-plate. The tentacles are smooth and moderately stout. 
Color, in alcohol, yellow brown.

Hassler Expedition; Barbadoes, 100 fathoms.

\section{Ophioscolex Stimpsonii sp. nov.}

Pl. I. f. $11-15$.

Special Marks. - Upper arm covered by a thin transparent skin, through which appear the upper surfaces of the arm-bones. Each tentacle furmished with a flap of skin standing outside of it. Lower surface and upper disk covered by thick skin.

Description of an Tulividual. - Diameter of disk, $7^{\mathrm{mm}}$. Width of arm without spines, $1.4^{\mathrm{mm}}$. Length of arm, $31^{\mathrm{mm} .}$ Mouth-papilla spiniform, blunt, somewhat rongh, imbedded in and nearly covered by the skin. There are nine to each mouth-angle, whereof one stands under the teeth. Besides these there may be seen, on each side, the spiniform tentacle-scale of the first pair of month-tentacles. Mouth-shields broad, oval, much obscured by the skin; length to breadth, .6: 1 . Side mouth-shields very small; not meeting within, nearly buried by the skin. Under arm-plates not visible except on drying or removing the skin, when they appear as small shield-shaped bodies, with an angle within, the sides re-enteringly curved and a strong noteh withont. In the same way may be distinguished the side arm-plates, which meet below, but stop above at the level of the upper surface of the arm (Fig. 13). At the tip of the arm the under arm-plate is nearly circular, and is set, like a werlge, between the outer ends of the elongated side armplates (Fig. 15). There are no upper arm-plates at all, and the arm-bones are to be seen through the thin skin, both at the base of the arm (Fig. 12) and at its tip (Fig. 14). Disk covered above and below with a thick but tender skin, there being neither scales nor radial shields visible. Arm-spines, outside the disk, three; short, slender, a little rough; the lowest one longest, namely, $.7^{\text {mm }}$ long. Tentacle-seales are represented by narrow pointed flaps of skin. one standing ontside of and close to each tentacle.

Color, in alcohol, gray brown.

Dr. William Stimpson; off Sombrero Key, 240 fathous.

It will be seen that this species does not agree with all the characters of Ophioscolex. Its unter arm-plates (nearly as in Ophiomyxa) and the flaps to the tentacles are features of difference. The type Ophioscolex glaciulis, which seems to have a naked thick-skinned disk, is really covered by thin, fine, 
regularly imbricated scales. Under the skin may be found the radial shields, which are perhaps smaller than in any other species among Ophiuridce. There are no upper arm-plates, nor do the side arm-plates meet above: a want which is not found even in Ophimnyxa, whose upper arm-plates are divided in several pieces, after the analogy of Oplioplocus, and are covered ly a thick skin.

\section{ASTROTOMA* gen. nov.}

Disk and arms granulated. Radial ribs low and narrow, running to centre of disk. Arms simple, and traversed by ammular ridges bearing microscopic spines. Tentacle-spines stout, erect, standing by all the pores except those (lose to the montl. No mouth-papille. Teeth and tooth-papillis similar and spiniform, arranged in a clump at the inner point of the mouth-angle. Two genital openings lying at the outer corners of each interbrachial space.

This simple-armed Astrophyton resembles Astromy $x$ in its dentition, while in the covering of the disk and arms and in the tentacle-spines it is between Astroscheme $(P l . I V . f .57,58)$ and Astrogomplus.

\section{Astrotoma Agassizii sp. nor.}

$$
\text { Pl. IV. f. } 52-56 \text {. }
$$

Speciul Marks. - Radial ribs slightly marked. Disk finely granulated; the under side of arms and surface round mouth more coarsely granulated. Tentacle-spines three or four; short, thick, slightly flattened, standing erect. Upper surfice of arm with low annular rilges which bear microscopic spines. One madreporic shield.

Description of an Intividual. - Diameter of disk, $20^{\mathrm{mm}}$. Width of arm without spines, $4^{\mathrm{mm}}$. Length of arm about $13 \mathrm{~S}^{\mathrm{mm}}$. Tooth-papilla and teeth represented by a clump of more than a dozen short, stont, sharp spines, like those of Astrophyton, and arranged at the inner apex of the mouth-angle, which has no spines near its outer corners. Arms cleanly rounded above; flattened below, where they are covered by a smooth granulation extending to the mouth region, which is separated from the interbrachial spaces by lines of coarser grains connecting the bases of the arms at the point where they blend in the disk. The arched upper surface of the arm is divided into 
joints by ammular ridges of granules bearing mieroseopie spines. Close to the tip of the arm, each joint has a ridge of two ammular rows of grains (Fig. 56), and each grain carries a mieroseopie spine. These two rows of spines interlock like the teeth of saws, and are folded flat to the arm. Between the ridges are depressions which are coverer by three amnular rows of grains. The madreporic plate lies in the mouth region inside the line of coarse grains connecting the bases of the arms; it is oval and surrounded by a setting of coarse granules. Disk ronghly circular, with ten slightly re-entering eurves at the brachial and interbrachial margins. Radial ribs feebly marked and ruming quite to the centre; they are more coarsely granulated than the rest of the upper surface (whose granulation makes a sort of network pattern), and have four or five grains in the length of a mm. Interbrachial spaces below distinguished from the mouth region by their smoothuess and their minute granulation. Tentacle-spines short, stout, blunt, slightly flattened, standing erect; there are none by the first pore, two by the second, and three or four by those beyond; their bases are surrounded by a little ridge of granulation, ontside which is the pore through which protrudes the small, short, smooth tentacle (Fig. 54). Close to the tip of the arm there are two spines to each pore; and here they are comparatively much larger, are eovered with skin and hooked at the end; at their base are two microscopie spines similar to those on the ridges of the arm (Fig. 56). The very tip of the arm is divided into joints, but, as yet, has no grains or minute spines; there is, however, a stout eurved tentacle-spine to each pore (Fig. 55). The genital openings are short, and lie at the outer corners of the interbrachial spaces.

Color, in alcohol, nearly white.

Hassler Expedition; Straits of Magellam, at the jumetion of Smythe's Channel, on the Pacific side; one specimen from 135 fathoms. 


\section{Table of the simple-armed Astrophytons.}

Teeth, tooth-papilla and mouth-papillie represented by a elump of snooth, rounderl, tapering spines, chielly at inner angle of jaws.

Teeth, tooth-papille, and month-papille all spiniform, but arranged somewhat as among Ophinrans, on the point of the jaws and along the lower edges of the mouthslits.

True teeth as among Ophiuridie. No tooth-papillie or mouth-papilla.
Genital openings at outer eorners of interbrachial spaces, and parallel to the arns, Skin granulate. Numerous peglike tentaele-spines . . . . . . . . . . . .

Genital openings at inner angle of interbrachial space. Skin (naked and soft. Thorny, hooked tentacle-spines . . . .

Genital openings near outer corners of interhraehial space and parallel to arms. Skin granulate and beset with stump's or spines. Arns prolonged into the lisk as strong ridges occupying most of its upper surface. Numerous tentachespines with thorny ends . . . . . . . . . . . .

Genital openings near onter corner of interbrachial space and parallel to arns. Skin granulate and beset with stumps or spines. Disk rising distinet from the arms. Numerous tentacle-spines with thoruy ends . . . . . . . . .

Genital openings vertical and at inner angle of interbrachial spaee. Skin naked and soft, a few (usually two) tentaclespines to each pore . . . . . . . . . . . . . .

Genital openings vertical ankl at inner angle of iuterbrachial space. Skin granulate. A few (usually two) tentacle-slines

to each pore . . . . . . . . . . . . . . Astroschema.
Astrotoma.

Astronyx.

Astroporpa.

Astrogomphus.

\section{Ophiocreas.}

\section{Table of the species of Astroschema.}

\begin{tabular}{|c|c|c|c|c|c|}
\hline & A. oligactes. & A. tenue. & A. læve. & A. Steenstrupii. & A. sulcatum. \\
\hline Tentaele-spincs & $\begin{array}{l}\text { Two, rounded taj- } \\
\text { ering, to each pore. } \\
\text { Towards middle of } \\
\text { arm, the one next } \\
\text { median line is } \\
\text { nuch longer and } \\
\text { stouter, and thorny } \\
\text { at the tip, but not } \\
\text { club-shaje. }\end{array}$ & $\begin{array}{l}\text { One small and } \\
\text { spiniform on each } \\
\text { of first two pairs of } \\
\text { pores; beyond that, } \\
\text { two to each pore. } \\
\text { Towards midlule of } \\
\text { arm, the larger one } \\
\text { isshort, club-shape, } \\
1 \text { mm. long, and } \\
\text { slightly thorny. }\end{array}$ & $\begin{array}{l}\text { None on first } \\
\text { pair, or two pairs } \\
\text { of pores ; a single } \\
\text { flat one till the sth } \\
\text { pore, where hegins } \\
\text { a small adlitional } \\
\text { one, at midule of } \\
\text { arm, alout as in } \\
\text { A. oligactes. (?) }\end{array}$ & $\begin{array}{l}\text { None on first } \\
\text { pair of pores; on } \\
\text { all beyond two } \\
\text { short and thick } \\
\text { ones. }\end{array}$ & $\begin{array}{l}\text { None on first } \\
\text { two pairs; then a } \\
\text { single small one; } \\
\text { farther ont, two. } \\
\text { Near midule of arm } \\
\text { the larger spine is } \\
\text { long, bent elub- } \\
\text { shape, audstrongly } \\
\text { thorny at the end. }\end{array}$ \\
\hline Diameter of disk & \begin{tabular}{l|l}
$8^{\mathrm{mm}}$. & $5^{\mathrm{mm}}$.
\end{tabular} & $6 \mathrm{~mm}$. & $7.5^{\mathrm{mm} .}$ & $7^{\mathrm{mm}}$ & $5^{\mathrm{mm}}$ \\
\hline Length of arm . & $140^{\mathrm{mm} .} \quad 53^{\mathrm{mm}}$ & $200^{\mathrm{mm}}$. & \begin{tabular}{l|l}
$135^{\mathrm{mm}}$ & $93^{\mathrm{mm}}$.
\end{tabular} & $\begin{array}{l}\text { About as in } A \text {. } \\
\text { oligactes. }\end{array}$ & \\
\hline Width of arm & \begin{tabular}{l|l}
$2.5^{\mathrm{mm} .}$ & $1.8^{\mathrm{mm} .}$
\end{tabular} & $1.5^{\mathrm{mm} .}$ & $3.5 \mathrm{~mm}$. & $2.5^{\mathrm{mm}}$ & \\
\hline $\begin{array}{l}\text { Grains on upper } \\
\text { surface of arm }\end{array}$ & 4 or 5 ; pointed & 8 or 9 ; smooth & 9 to 15 ; smootl & $\begin{array}{l}\text { Grains not close, } \\
\text { but set in lines. }\end{array}$ & $\begin{array}{l}\text { Abont } 9 \text { to } 15 \text {; } \\
\text { smooth. }\end{array}$ \\
\hline Disk & $\begin{array}{l}\text { Radial ribs wide, } \\
\text { not frominent; } \\
\text { margin of disk } \\
\text { angular; surfaee } \\
\text { rough, with sharp } \\
\text { grains. }\end{array}$ & $\begin{array}{l}\text { Radial ribs nar- } \\
\text { row and not [rom } \\
\text { inent ; margin of } \\
\text { disk angular; sur- } \\
\text { face smooth, with } \\
\text { small grains. }\end{array}$ & $\begin{array}{l}\text { Radial ribs wide } \\
\text { and arehed, ocen- } \\
\text { fying the whole up } \\
\text { - persurface; the ma- } \\
\text { gin with } 10 \text { curves. } \\
\text { Granulation fine } \\
\text { and smooth. }\end{array}$ & $\begin{array}{l}\text { Radial ribs and } \\
\text { margin as in } A \text {. } \\
\text { lace. Granulation } \\
\text { arrunged in more } \\
\text { or less concentric } \\
\text { lines. }\end{array}$ & $\begin{array}{l}\text { Radial ribs nar- } \\
\text { row and not run- } \\
\text { ning to the centre. } \\
\text { Granulation fine. }\end{array}$ \\
\hline
\end{tabular}




\section{Astroschema tenue sp. nov.}

Special Marks. - Arms slender, and in length more than thirty times the diameter of the disk. Radial ribs narrow and ruming to the centre. Disk and arms smoothly gramulated.

Description of an Individual. - Diameter of disk, $6^{\mathrm{mm}}$. Length of arm, $200^{\mathrm{mm}}$. Width of arm near base, $1.5^{\mathrm{mm}}$. Teeth wider than long, with a curved cutting edge. The general granulation becomes coarser on the mouth-angles, and some of the larger grains extend upward on the sides of the mouth-slits. Arms very slender and long; above and on the sides the joints are indicated by gentle swellings, but the lower surface is flat. The upper surface of the disk presents ten narrow rarial ribs which meet in the centre; the rlisk margin between the ribs is re-enteringly curved. Upper disk and arms elosely granulated with smooth grains, whereof there are eight or nine in a mm. long; on the radial ribs they are somewhat coarser. The lower side of the arm has a much finer and more scattered granulation. Each of the first two pairs of tentacle-pores has a single small, thorn-like tentacle-spine; the pores beyond have two. Towards the middle of the arm the tentacle-spine nearest the median line becomes much longer and larger, $1^{\mathrm{mm}}$ long, and has a club-shape, with fine thorns at its end; while its fellow retains its previous form. The mouth-tentacles project from little tubes, which may also be seen on the pores of the base of the arm. Genital openings standing close together at the imer angle of the interbrachial space and separated by a partition.

Color, in aleohol, nearly white.

Hassler Expedition; Barbadoes, 100 fathoms.

This species stands nearest to A. olignctes, from which it is readily distinguished by the longer and more slender arms, and by a gramulation smooth and fine, instead of coarse and pointed.

In a former paper (Amales des Sc. Nat., 1872, p.5) I expressed a doubt of the distinction made by $\mathrm{Dr}_{\mathrm{r}}$. Lïtken between Astrosehma and Astromorpha, founded on the position in the last genus of the genital openings in a hollow. By examining numerous alcoholic specimens of $A$. oligactes, I have been convinced that this is not a valid difference. The real peculiarity in these, as well as in Ophiocreas, is that the genital openings are at the inner angle of the interlsachial space and are nearly vcrtical, instead of being horizontal and placed alongside the arms. The genus Astromorpha may therefore be merged in Astroschema. 


\section{Astrophyton Pourtalesii sp. nov.}

$$
\text { Pl. } I V . f .41-43 \text {. }
$$

Syreciul Mrerlis. - Disk round and fleshy, covered by a thick skin, through which show numerous grains on the upper surface. Three or four tentaclespines to each pore, extending to within one or two pores of the mouth. One madreporic body, often covered by the skin, and situated at the inner angle of the interbrachial space.

Description of an Individual. - Diameter of disk, $63^{\mathrm{mm} .}$ Width of arm where nal'owest within the disk, $8^{\text {mm. }}$. Width of largest branch, outside disk, $8^{\text {mm. }}$ Total length of arm measured along its branches, 204m, to wit: 1st fork (which is within the disk) to the $2 \mathrm{~d}$ (which is ontside), $16^{\mathrm{mm}} ; 2 \mathrm{~d}$ to $3 \mathrm{~d}$, $32^{\text {mm. }} ; 3 \mathrm{ll}$ to $4 \mathrm{th}, 30^{\mathrm{mm} .} ; 4$ th to $5 \mathrm{th}, 27^{\mathrm{mm} .}$; 5 th to $6 \mathrm{th}, 29^{\mathrm{mm}} ; 6 \mathrm{th}_{\mathrm{l}}$ to $7 \mathrm{th}$, $27^{\mathrm{mm}} ; 7$ th to 8 th, $15^{\mathrm{mm} .}$; Sth to $9 \mathrm{th}, 10^{\mathrm{mm} .} ; 9$ th to $10 \mathrm{th}, 7^{\mathrm{mm}} ; 10$ th to $11 \mathrm{th}$, $7^{\mathrm{mm}}$; 11th to end, $4^{\mathrm{mm}}$. Nouth-papilla, teeth, and tooth-papillae all similar and spiniform; small, nearly equal, and about a dozen to each mouth-angle. Arms smooth, covered with thiek skin, and rounded. The terminal twigs have their joints marked by annular ridges ( $F$ ig. 4.3), which bear a double row of minute spines, folded down on the ridge, and alternating with one another. Disk fleshy, nearly circular, and covered by a thick skin; the radial ribs slightly marked. There are neither spines nor stumps, but a quantity of scattered granules, which are most plenty near the centre of the back, and are almost wanting in the lower interbrachial spaces. At the inner angle of one of the interblachial spaces is the madreporic shield, which is so coverer by skin as to be hard to distinguish. Three or four tentacle-spines on all the larger branches; short, blunt, spiniform, of equal size; about $2^{\mathrm{mm}}$ long. On the two pairs of pores nearest the mouth, no spines, or only a single one; the following three or four pores have two spines each; and those beyond, three or fonr. Each pore on the terminal twigs has but two tentacle-spines, in form of strong spiny stumps covered with skin (Fig. 4.3, q), elose to which the tentacle $\left(q^{\prime}\right)$ protrudes.

Color, in alcohol, nearly white.

A larger specimen had the disk $75^{\mathrm{mm}}$ in diameter. The distances from one fork of the arm to the next were as follows: 1 st to $2 \mathrm{~d}, 14^{\mathrm{mm}} ; 2 \mathrm{~d}$ to $3 \mathrm{~d}$, $29^{\mathrm{mm} .}$; $3 \mathrm{~d}$ to $4 \mathrm{th}, 27^{\mathrm{mm}}$; 4th to $5 \mathrm{th}, 29^{\mathrm{mm}}$; 5th to $6 \mathrm{th}, 21^{\mathrm{mm}}$; 6 th to 7 th, $18^{\mathrm{mm} .}$; Tth to $8 \mathrm{th}, 14^{\mathrm{mm} .}$; Sth to $9 \mathrm{th}, 14^{\mathrm{mm}}$; 9 th to $10 \mathrm{th}, 10^{\mathrm{mm} .} ; 10$ th to $11 \mathrm{th}$, $10^{\mathrm{mm}} ; 11$ th to $12 \mathrm{th}, 8^{\mathrm{mm}} ; 12$ th to $13 \mathrm{th}, 7^{\mathrm{mm}} ; 13 \mathrm{th}$ to end, $7^{\mathrm{mm}}$; in all, 
$208^{\mathrm{mm}}$. It had more abundant grannlation on the upper surface of the disk, but was otherwise similar to the one first described.

Hassler Expedition; off East Patagonia, lat. $44^{\circ} 52^{\prime}$ S., long. $64^{\circ} 10^{\prime} \mathrm{W}$, and lat. $51^{\circ} 26^{\prime} \mathrm{S}$. , long. $68^{\circ} 5^{\prime} \mathrm{W}$., 55 fathoms.

This fine Astrophyton belongs to the group whose arms are narrow at their base, and the forkings few and distant. The species of cold and temperate waters fall in this group, snch as $A$. euenemis, A. Lamarckii (which resembles the one under consideration), and A. Agassizii. The second group, whose types are $A$. costostm and $A$. spinosum, has the arm wide at its base, and divided often and at short intervals; its habitat is in tropical seas. Where the one would have a width of $S^{\mathrm{mm}}$, and a dozen or fifteen forks in the arm, the other would have $14^{\mathrm{mm} .}$ and twenty-five or thirty forks (Figs. 41 and 4 ), whereof three would be within the disk, which is not circular, but deeply re-entering at each interbrachial margin.

What are spoken of as tentacle-spines are so named from their proximity to the pores. They might be ealled also arm-spines, becanse they are carried by the rudimentary side arm-plates, as may be seen in a young Astrophyton (Lütken, Addilamenta ad Ihist. Ophimid., Pt. I., Pl. II. f. 1r, b). The hooklets, or small spines, which stand on annular ridges and usually in double rows, on the arms of all Astrophytide ( $P l . I V . f .43,46,51,56$ ), are not immediate homologues of arm-spines, but are comparable to skin granules. Among Ophiuridie, however, such booklets are true arm-spines ( $P$. $I$ I. $f$. 6o, p., Ophiothclu isidicole), attached to side arm-plates (i).

\section{Astrophyton spinosum sp. nor.}

$$
\text { Pl. IV.f. } 44-46 \text {. }
$$

Specirl Mfarls. - Interbrachial spaces of disk deeply indented. Radial ribs thick and high. Little clumps of three or four spines at each joint on the upper median arm-line. Arm forked three times within the disk. No tentacle-spines on the pores near the base of the arm. Five madreporic bodies lying at the inner angles of the interbrachial spaces.

Description of an Individual. - Diameter of disk, $42^{\mathrm{mm}}$. Width of arm where narrowest, inside disk, $15^{\mathrm{mm}}$. Width of largest branch, outside disk, $6^{\mathrm{mm}}$. Total length of arm, measured along its branches, $28 \mathrm{~S}^{\mathrm{mm}}$, to wit: from $1 \mathrm{st}$ to $2 \mathrm{~d}$ (both within margin of disk), $14^{\mathrm{nm}} ; 2 \mathrm{~d}$ to $3 \mathrm{~d}, 14^{\mathrm{mm}} ; 3 \mathrm{~d}$ to $4 \mathrm{th}, 14^{\mathrm{mm}} ; 4$ th to 5 th, $16^{\mathrm{mm}}$; 5 th to $6 \mathrm{th}, 15^{\mathrm{mm}} ; 6$ th to $7 \mathrm{th}, 18^{\mathrm{mm}} ; 7$ th to 8 th, $15^{\mathrm{mm} \cdot}$; 8 th to 
9 th, $15^{\mathrm{mm} .}$; 9 th to 10 th, $16^{\mathrm{mm}}$; 10 th to 11 th, $16^{\mathrm{mm} .}$; 11 th to 12 th. $15^{\mathrm{mma}} ; 12$ th to $13 \mathrm{th}, 15^{\mathrm{mm} .}$; 13 th to $14 \mathrm{th}, 13^{\mathrm{mm} .} ; 14$ th to $15 \mathrm{th}, 12^{\mathrm{mm} .} ; 15$ th to $16 \mathrm{th}, 13^{\mathrm{mm} .}$; 16 th to $17 \mathrm{th}, 12^{\mathrm{mm} .} ; 17$ th to $18 \mathrm{th}, 10^{\mathrm{mm} .}$; 18 th to $19 \mathrm{th}, 8^{\mathrm{mm} .} ; 19$ th to 20 th, $7^{\mathrm{mm}} ; 20$ th to $21 \mathrm{st}, 7^{\mathrm{mm}} ; 21 \mathrm{st}$ to $22 \mathrm{~d}, 6^{\mathrm{mm}} ; 22 \mathrm{~d}$ to $23 \mathrm{~d}, 6^{\mathrm{mm} .} ; 23 \mathrm{~d}$ to $24 \mathrm{th}$, $6^{\mathrm{mm}} ; 24$ th to end, $5^{\mathrm{mm}}$. Teeth, mouth-papille, and tooth-papillæe all similar and spiniform; they are sharp and slender, in number twenty or more, and form a close high clump on the mouth-angle. Arms, near the disk, wide and flat below and covered by a smooth skin; above, arehed and invested with a fine smooth granulation about six grains in the length of a mm. On the upper median line there is to each joint a row of four or five little spines about $.5^{\mathrm{mm}}$ long; and at their base there usually is a large rounded grain (Fig. 47). These spines are found well out on the arm. The terminal twigs have their joints marked by annular ridges, each composed of a double row of grains, which support little hooklets. The depression between the joints is covered by a double row of rounded grains (Fig. 46). Disk strongly indented along its margin, and having deep radiating furrows on the back. Its skin is smooth except a number of small spines like those on the back of the arms, which are sparsely scattered in twos and threes over the upper surface. At the inner angle of each of the interbrachial spaces is a madreporic shield. There is no trace of tentacle-spines near the base of the arm; but, outside the fifth fork, there are two or three to each pore, similar in shape to those on the upper surface of the arm. Tentacle-pores closely contracted, and only recognized by the little pits that mark their position. Radial ribs high and wide, occupying a large part of the upper surface; extending to the centre of the disk and projecting over the arms.

Color, in alcohol, purplish-brown.

Panama; brought up by Wesley Clark, a noted diver, and presented by Mr. Landsberg.

This new species represents, on the Pacific side, A. costosum of the West Indies, although it differs widely in its details. A. costosum has a few thick stumps on the upper disk and the radial ribs, while $A$. spinosum has clumps of minute spines.

Cambringe, January $13,1875$. 


\section{EXPLANATION OF THE PLATES.}

\section{PLATE I}

Ophiomusium acuferum, Figs. 1-5. Fig. 1, 9, under surface, showing the mouth-tentacles, the curved genital openings, and the two under arm-plates which have tentacles. Fig. 2, $\frac{9}{1}$, upper surface, with its peculiar plates and the spines on the back of the arm. In this species and the succeeding one the surface is shown smooth, as it appears nnder water; when dry, it is seen to be cosered with microscopic points. Fig. 3, $\frac{3}{1}$, a portion of the arm, near its tip, from below, showing the complete investment by the side arm-plates. Fig. 4, 20, the jaws and adjacent parts, from the side: $c$, the jaws; $e$, jaw-plate ; $c^{\prime \prime}$, teeth ; $d$, mouth-papilla ; $r, r^{\prime}$, the sockets of the second and first pairs of mouth-tentacles. The rudimentary state of the apparatus will be observed: shapeless jaws, small jaw-plate, few and irregular teeth, and the closely soldered mouth-papille. Fig. 5, 20, a tentacle of one of the two under arm-plates with its clapper-like scale,

Ophiomusium testudo, Figs. $6-8$. Fig. $6, \frac{12}{1}$, under surface, showing two of the mouthtentacles, the absence of an under arm-plate on the third joint, and the peculiar marginal diskplates. Fig. $7,1_{1}^{2}$, upper surface, with the intimately soldered plates. Fig. 8, $1_{1}^{2}, 3 d, 4$ th, and 5 th arm-joints, with their two or three minute arm-spines.

Ophiacantha marsupialis, Figs. $9-10,20$. Fig. 9, under surface. The arms of a young one protrude from the genital openings. The peculiar shape of the jaws will he observed; and the umusual size of the first under arm-plate, which completely encloses the second pair of mouthtentacles. Fig. 10, upper surface.

Ophioscolex Stimpsonii, Figs. 11-15. Fig. 11, 辛, under surface. The outlines of some of the parts are dimly seen throngh the thick skin. Each tentacle has a flap of skin outside it;

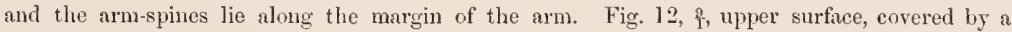
thick integument, which is projected over the upper surface of the arms as a transparent film, through which the upper edges of the arm-bones may be seen, and their muscular bundles. Fig. 13, $1_{1}^{2}$, under surface of an arm-joint, with skin removed to show the plates. The small under arm-plate and the side arm-plates are much as in Ophiomyxa. Outside each tentacle is its peculiar flap of skin; and, next this, the lowest arm-spines slightly denticulated. Fig. 14, $1_{1}^{2}$, upper siuface of a joint at tip of arm; the side arm-plates do not meet above, nor is the vacant space corered by any upper arm-plate. Fig. 15, $1_{1}^{2}$, the joint from below. Wedged between two side arm-plates is a circular under arm-plate, outside which are the tentacles with their flaps, and the undermost arm-spines. 


\section{PLATE II.}

Ophiacantha stellata, Figs. 16-18. Fig. 16, 20, under surface. The difference between the second and third under arm-plates is to be noted. Just ontside the second small spine of the second plate (on the arm to the right of the observer) may be seen protruding the minute tentacle. Fig. 1 $\bar{i}$, 20, upper surface, showing the small, deeply iudented disk aud the peculiar side arm-plates, constricted between the joints, and rising suddenly into a ridge for the armspines. These characters, and the narrow, nearly covered radial shields, are those of the typical 0 . setosa, from which so many species now referred to the genus vary. Fig. 18, $\frac{8}{1}$, three joints, seen from above, to show their characteristic form.

Ophiacantha hirsuta, Figs. 21-23. Fig. 21, 11, under surface, with the unusually long jaws, large mouth-tentacles, and the first under arm-plate partly rolled on itself. Fig. 22, $1_{1}^{1}$, upper surface, showing the numerous fine spines. Fig. $23, \frac{50}{1}$, the lowest arm-spine, to exhibit the peculiar thorns of its point and edges.

Ophiomitra cervicornis, Figs. 19-20, 9. Fig. 19, under surface. The first under arm-plate is folded on itself, and the small month-tentacle of the second pair protrudes between it and the outer corner of the side mouth-shield. On the mider arm-plates, beyond, the tentaclescales have, first, the shape of thorny erescents, and then of little lobes. Fig. 20, upper surface, showing the large radial shields and the coarse spines and stumps of the disk.

Ophioplax Ljungmani, Figs. 24, 25, $\frac{1}{1}$. Fig. 24, upper surface; the scales of the margin are corered by a minute granulation. Fig. 25, under surface, showing the singnlar oral tentaclescale, with three or four minute ones on the under arm-plate. The interbrachial space is finely granulated.

\section{PLATE III.}

Amphiura anomala, Figs. $26-28$, 10. Fig. 26, under surface. On the right side of the mouth-angle are seen three, aud on the left only two month-papillae. Above these are the large month-tentacles; and still higher may be seen the points of the scales of the first pair of mouthtentacles. Fig. 27, upper surface. Fig. 28, arm-spines, from the side.

Amphiura Barbarz, Figs. $32-34, \frac{12}{1}$. Fig. 32, under surface. The tentacles are thick ; their scales miunte. Fig. 33, upper surface, with wide upper arm-plates. Fig. 34, arm-spines.

Amphiura flexuosa? LJs., Figs. $35-37$. Fig. 35, $\frac{15}{1}$, under surface, showing its very minnte, feeble scaling. Inside the month-shield are two small mouth-papillie, followed by the little jaws bearing the other pair of papillæ; beside these are seen the second pair of mouthtentacles, and the scales of the first pair. Fig. $36, \mathcal{1}_{1}^{5}$, npper surface, with the radial shields separnted by a central row of scales, and some others, ill-defined, on either side. Fig. $37, \frac{60}{1}$, thind and fourth arm-spines, which differ from the rest in being stonter, a little rough, and in having a microscopic beak at the tip. See also Plate V. Fig. 68.

Amphiura repens, Figs. $38-40$, 1, $1^{6}$. Fig. 38, under surface. Most of the interbrachial space is naked, as in A. semiermis. The narrow jaw carries six bead-like mouth-papille. Fig. 39, unper surface, which much resembles that of the East lndian A. Levis. Fig. 40, arm-spines.

Ophioceramis albida (Amphipholis Ljx.), Figs. 29-31, ㅅ․ Fig. 29, under surface. The large side nonth-shields, numerous mouth-papillæ, and short genital openings are the char- 
acters here to he seen which scparate it from Amphiura. The small tentacles are somewhat protruding, each with its two scales. Fig. 30, upper surface, showing the strong, coarse sealing and thick upper arm-plates of the genus. Fig. 31, arm-spines.

\section{PLATE IV.}

Astrophyton Pourtalesii, Figs. $41-43$. Fig. $41, \frac{1}{1}$, under surface of the interbrachial space which has the nuatreporic body. On the month-angle are the few and small tooth-spines, and the month-tentacles. Following the arm, the first joint has tentacles with no spine; the joints beyond have, for the most part, three or four spines to each tentacle. The narrowness of the arm and the single fork within the disk will be noted as compared with the broad arm and three forks of Fig. 44. Fig. 42, 1, upper surface, showing the low radial ribs, sparse granulation, and smootl arms. Fig. $43, \frac{15}{1}$, a joint at the tip of the arm, showing the peculiar minute spines, which are folded down, wore or less covered by skin, ancl placed in two alternating rows. Below are the large tentacles $\left(q^{t}\right)$, and their hooked spines $(q)$, eased in skin, of which there are two to each pore on this part of the arm. The northern species, A. Agrssizii, has also two large tentacte-spines to each pore at the tip of the arm (Figs. $\left.49,50, q, q^{\prime}\right)$, with a ridge correspond. ing. In Fig. 50, a tentacle may be seen protrnding from several of the pres.

Astrophyton spinosum, Figs. 4t-47. Fig. 4t, $\frac{1}{1}$, under surface, with one of the five madreporic shields. At the month-angle is a crowded clump of numerons tooth-spines, and, on either side, a mouth-tentacle; just outside is a double swelling, which is a part of the jaws. There are no tentacle-spines on the broad arms, and the pores are represented only by feeble depressions. Fig. 45, $\frac{1}{1}$, upper surface, with the wide high radial ribs, and the broad eicatriees at their outer ends. On the disk and arms are the characteristic groups of small spines. Fig. 46, $\frac{\text { sin }}{\mathrm{T}}$, a joint from tip of arm. Each ridge has a donble row of granules bearing minute books; and each depression has also a double row of granules, which have not so much of a pit in their centre as is represented in the drawing. A joint of similar character is that of $A$. crecaticum, Fig. 5I, where the specimen was dried and many of the hooklets rubbed off, showing the granules on which they stood. It must be borne in mind that these granules do not eorrespond to side arm-plates, nor their hooklets to arm-spines. Where booklets are found anong Ophiuridie they are arm-spines and stand on side arm-plates, as may be seen in the young of Ophiothelu isidicola, Fig. 60, where an arm-spine $(p)$ and hooklets $\left(p^{\prime}\right)$ are found on the side arm-plate $(i)$. Fig. 47, 6 , upper surface of arm. near the disk, to show the granulation, and the row of small spines which erowns each joint.

Astrophyton exiguum, Fig. 48, 年. Upper surface, from the original and unique speeimen of Lamarck in the Garden of Plants. The specimen has the granulation partly rubbed off, exposing the compound radial shields or ribs $(l)$ which characterize the genus. It doubtless is a young one, which adds to the trouble of fiuding what the species really is.

Astrophyton Agassizii, Figs, 49, 50. Tip of arm. from a living specimen, much magnified ; side, and under surface.

Astrophyton cacaoticum, Fig, 51. Joint from tip of arm, dried, and much magnifierl.

Astrotoma Agassizii, Figs. 52-56. Fig. 52, 1, disk and one arm complete, from above.

Fig 53, 3 , under surface, showing the finer and coarser grannlation, the Astrophyton-like tooth- 
spines; the madreporic shield, and the strong, upright tentacle-spines. The first pore, outside the mouth-slit, has a small tube but no spine. From the pores on either side of the madreporic plate may be seen protruding the small tentacle covered by two spines. Fig. 54, f, a tentaclepore with its three spines mounted on a granulated ridge. Fig. 55, 25, tip of an arm rolled on itself; there are, as yet, no granules or small spines; but the curved tentacle-spines are formed. Fig. 56, 25 , a joint close to tip of arm. The ridges have two rows of granules, each bearing a minute jointed spine which is usually folded down, the whole fitting together like fingers of two hands. The intermediate sunken space is covered hy three rows of gramules. Below are seen the large tentacle-spines $(q)$, hooked at the end and covered by thick skin; on the base of the exterior one are two little spines similar to those of the granulated ridges above.

Astroschema leve, var., Figs. 57-59, from original in the Garden of Plants. Fig. 57, $\rho$, under surface of a dried specimen. The mouth-angles have only teeth. The first pore has no scale; the second, one. The gramulation in this figure and the next is made too coarse; there should lie twelve or fifteen grains in the length of $6^{\mathrm{mm}}$. Fig. 58, $\frac{6}{1}$, upper surface, showing its regular division in lobes with curved margin, and the arm-joints as successive swellings. Fig. 59 , $\frac{4}{1}$, interbrachial space seen horizontally from without, exhibiting the vertical genital openings at the inner angle. The specimen varies from the type in having a finer disk-granulation.

Ophiothela isidicola, Fig. 60, ${ }_{1}^{40}$, to show the relation of arm-spines $(p)$ and hooklets $\left(p^{\prime}\right)$ to the side arm-plates (i) among Ophiuridre.

\section{PLATE V.}

Outlines of the month-angles, month-shields, and under arm-plates of twenty-four species of Amphiura, to exhibit the leading forms. The Ampliure, in the restricted sense of Ljungman, are put first (Figs. $61-68$ ), to wit, those which have only four papille to each angle, while the tentacle-scales of the first mouth-tentacles are seen higher up. Then follow species that have six or eight papillæ to each angle (Amphipholis Ljn.), among which will be noticed a great variety in size, form, and relntion of parts. Between Figs. 68 and 69 would naturally come A. anomala, Pl. IlI. Fig. 26, an intermediate form, which satisfies me that there is no reason for cutting the old genus Amplinura in two. Fig. 68 is from an older and larger specimen than Fig. 35, Plate III. 


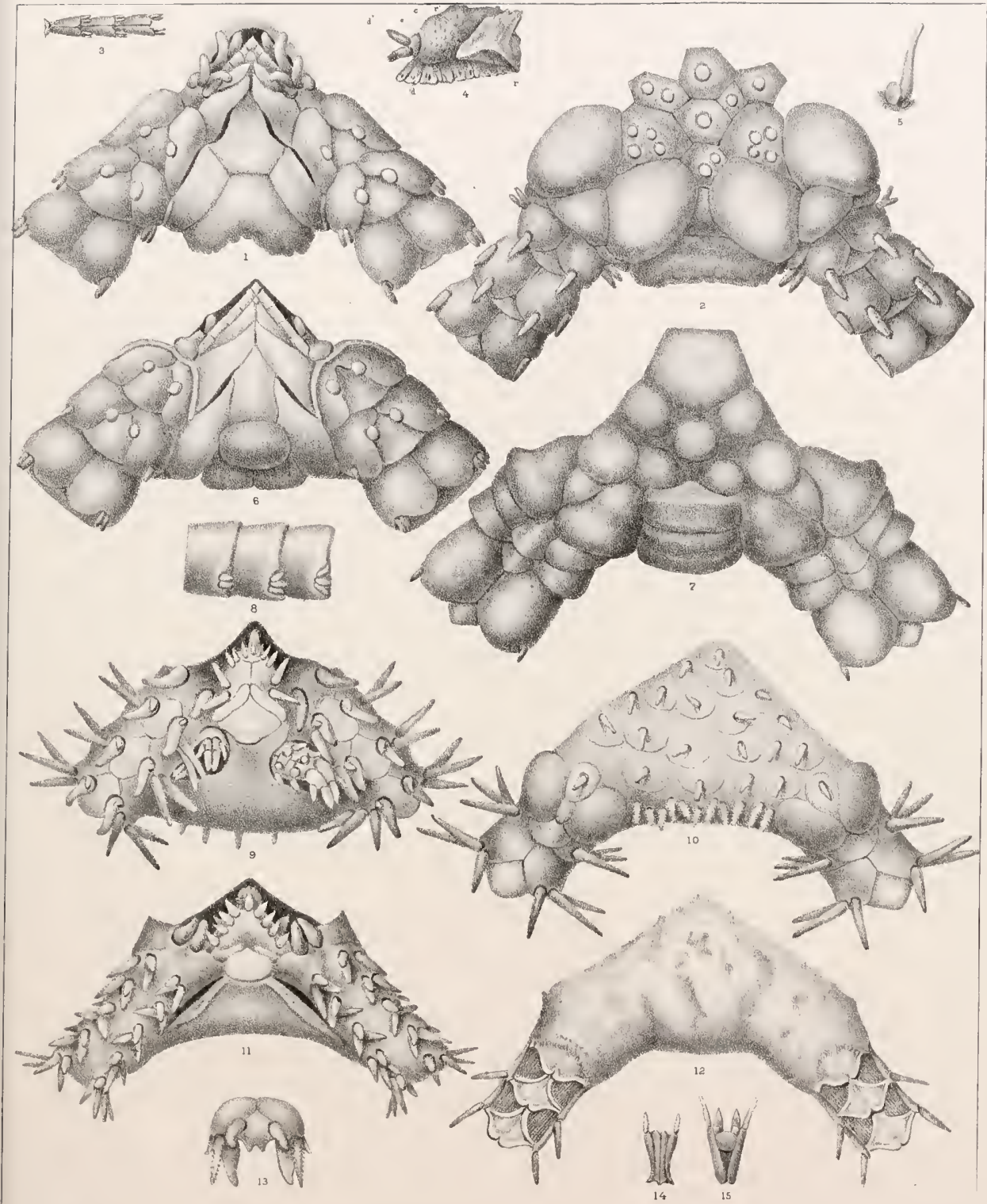





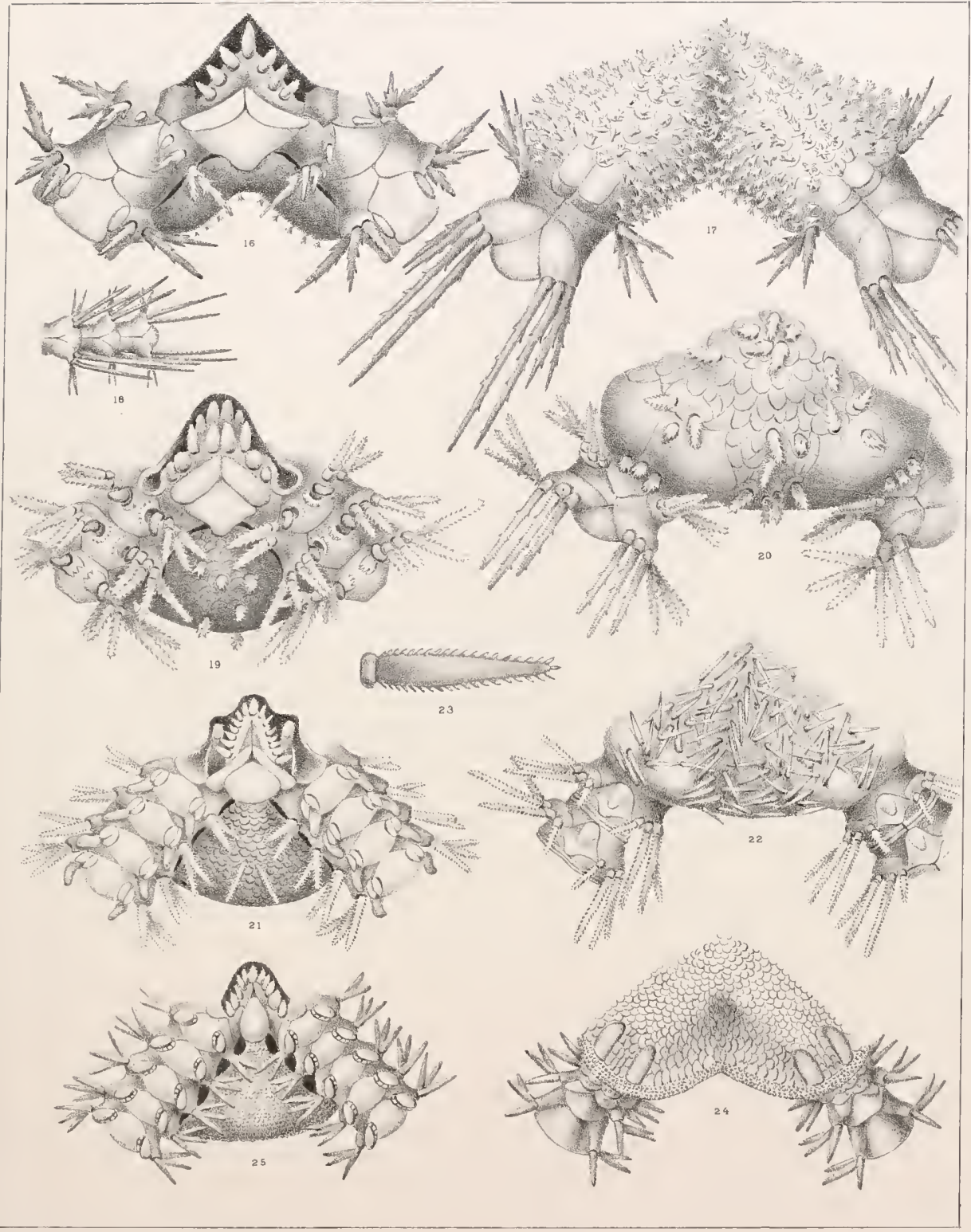

P Roetter lith 



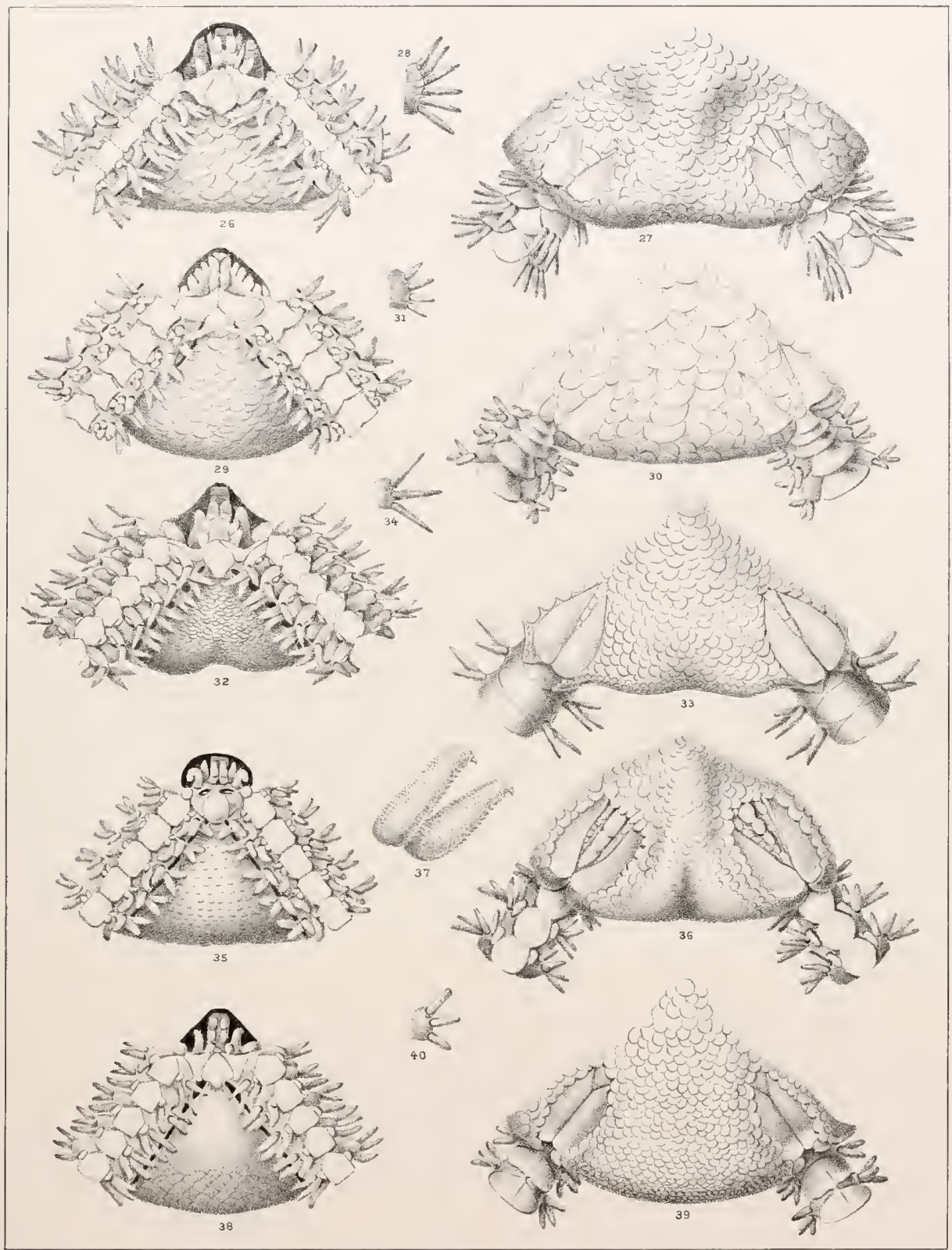





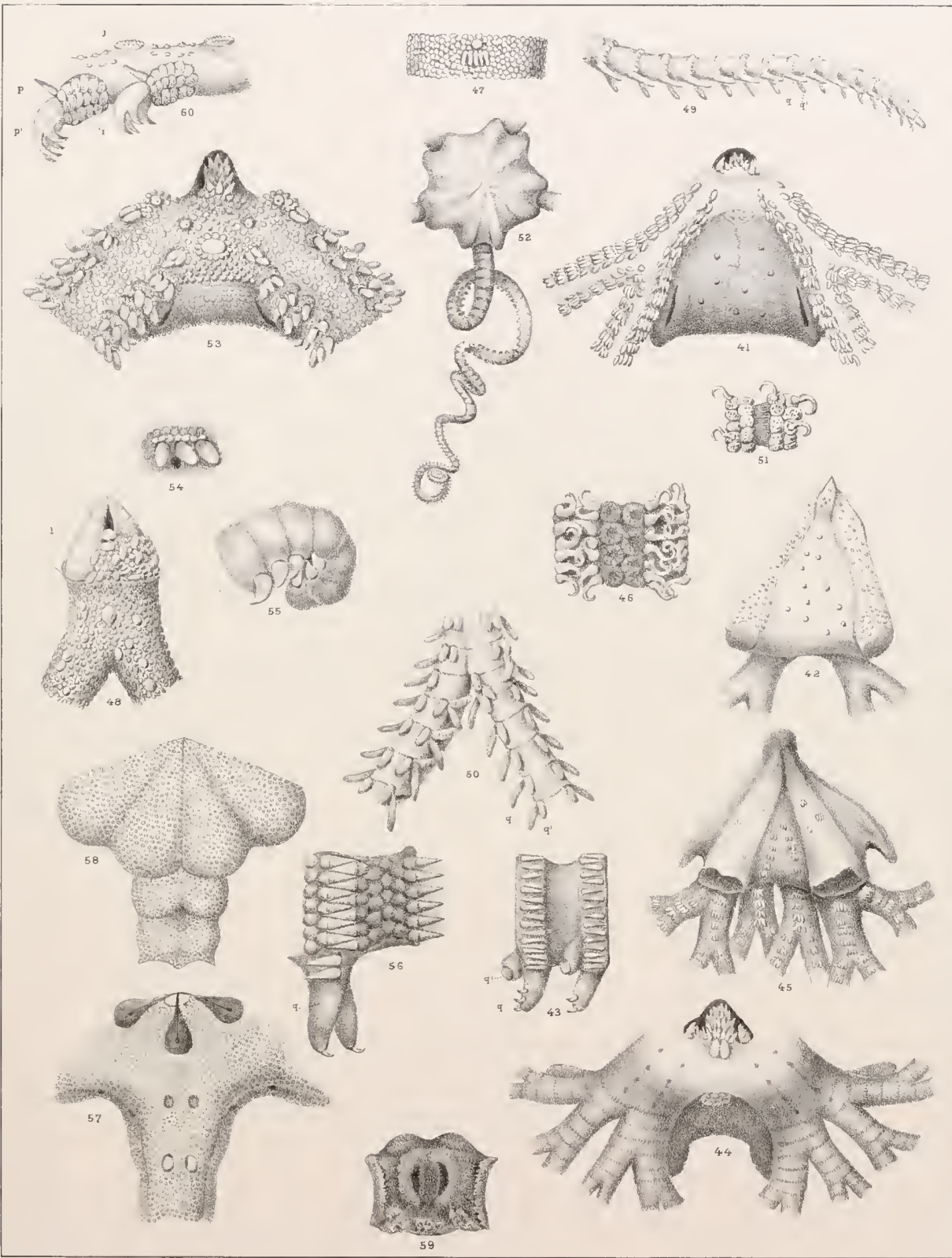





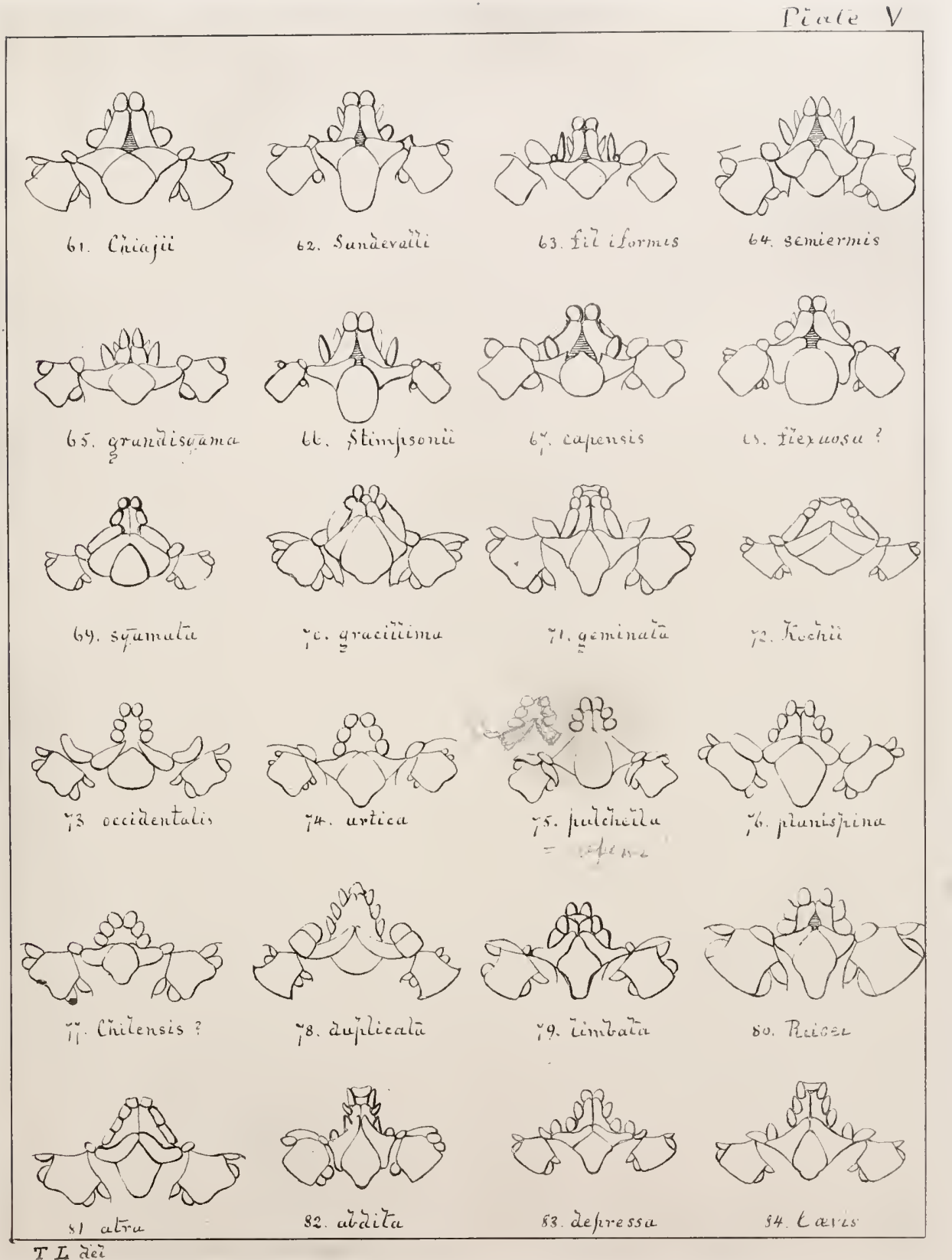

9107002 






\section{Date Due}

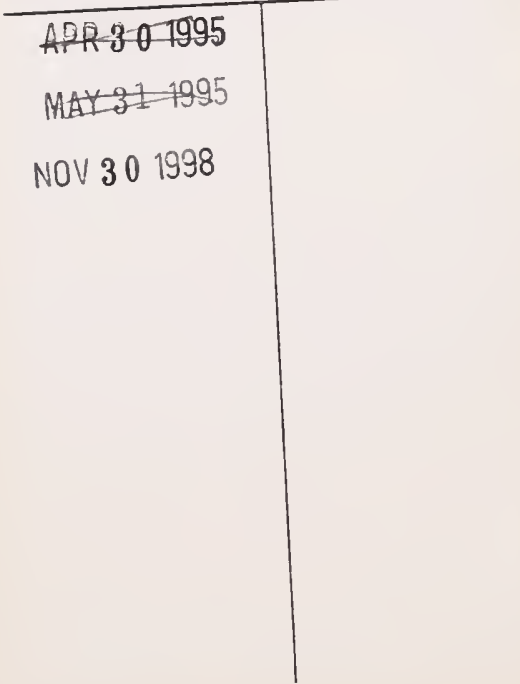

$$
\begin{aligned}
& \text { AT:AE } \\
& \text { BBกK? : ij. INC. } \\
& \text { AUG } 201984 \\
& \text { DOU CAMBRIDGE STREET } \\
& \text { CHA:Z!ESTOWIN. MASS. }
\end{aligned}
$$




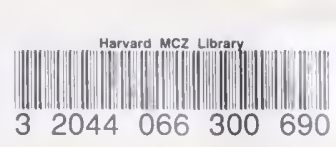


